CLAUDIA LUPOLI DE ALMEIDA

\title{
A construção de identidade do aluno disléxico no ambiente de ensino e aprendizagem da língua inglesa
}

(Versão corrigida)

Dissertação de Mestrado apresentada ao Programa de Pós-Graduação em Estudos Linguísticos e Literários em Inglês do Departamento de Letras Modernas da Faculdade de Filosofia, Letras e Ciências Humanas da Universidade de São Paulo, como parte dos requisitos para obtenção do título de Mestre.

Orientadora: Prof. Dra. Elizabeth Harkot-De-La-Taille

São Paulo 
Autorizo a reprodução e divulgação total ou parcial deste trabalho, por qualquer meio convencional ou eletrônico, para fins de estudo e pesquisa, desde que citada a fonte.

AABCC

Almeida, Claudia Lupoli

A conatruçoso de identidade do aluno dialexico no ambiente de enaino e aprendizagen da 1 ingua ingleas / Claudia Lupoli Almeida ; orientador Blizabeth Harkot-De-La-Taille. - Slao Paulo, 2017.

$151 \mathrm{f}$.

Dismertação (Meatrado) - Faculdade de Filonofia, Letras e Ciêncian Humanas da Univeraidade de Säo Paulo. Departamento de Letran Modernas. Área de concentraç̃o: Batudoe Linguiaticoa e Litersirioa em Ingles.

1. Dialexia. 2. Lingua ingleas. 3. Senibtica discuraiva. 4. Identidade diacuraiva. 5. Enainoaprendizagem. I. Harkot-De-La-Taille, Blizabeth. orient. II. Titulo. 
ALMEIDA, C. L. A construção de identidade do aluno disléxico no ambiente de ensino e aprendizagem da língua inglesa. Dissertação apresentada à Faculdade Filosofia, Letras e Ciências Humanas da Universidade de São Paulo para obtenção de título de Mestre em Estudos Linguísticos e Literários em Inglês.

Aprovada em:

Banca Examinadora

Prof. Dr.

Instituição:

Julgamento:

Assinatura:

Prof. Dr.

Instituição:

Julgamento:

Assinatura:

Prof. Dr.

Instituição:

Julgamento:

Assinatura: 
Para Celso Lupoli, meu avô querido, cujos passatempos sempre aguçaram minha curiosidade.

Para Irmã Iriema Trevisan, professora querida que me ensinou disciplina e amor aos estudos.

In memoriam

Para minha mãe, Maria Aparecida, pelo amor e apoio incondicionais em todos os meus projetos.

Para Jordan Bandeira, por olhar para meu trabalho com tanto carinho. 


\section{Agradecimentos}

À minha querida mãe, Maria Aparecida Lupoli, pelo apoio nos pequenos e grandes projetos, pelo orgulho demonstrado em cada etapa e conquista e pelo eterno acreditar em minhas capacidades.

A Jordan Hahn Bandeira, parceiro de leituras, ideias, sugestões - e de pós-graduação. Agradeço por todas as vezes nas quais pensou em meu trabalho antes do seu, procurou por livros e material de apoio e levantou questões que me ajudaram a repensar parágrafos e capítulos. Agradeço pela ajuda no dia a dia e por ter tirado de minhas costas o peso de cuidar de detalhes pequenos, mas essenciais, de última hora.

Às amigas, que mantiveram os ouvidos (e corações abertos) nos momentos de cansaço e desânimo: Denise Martins Américo de Souza, professora competente e sábia, e Rose Santiago, compreensiva e incentivadora. Às duas, obrigada por terem mantido a fé em mim.

Pelos familiares e amigos que torceram e expressaram seu apoio das formas mais variadas.

À minha orientadora, Elizabeth Harkot-De-La-Taille, por ter visto a possibilidade de um caminho para meu trabalho antes mesmo de mim. Agradeço pela chance de ser aluna ouvinte, que me preparou de modo essencial para 0 mestrado, pela oportunidade, confiança e suporte durante todo o processo.

À Associação Brasileira de Dislexia (ABD), especialmente à fonoaudióloga Maria Ângela Nico e ao psicólogo Luiz Gustavo V. Simi, que carinhosamente me receberam, abrindo as portas da instituição para minha pesquisa e respondendo meus questionamentos.

Aos seis entrevistados para este trabalho, cuja confiança em mim me deixaram profundamente emocionada. Pelo coração aberto de cada um e pela generosidade com a qual abriram suas histórias de vida para mim. Gratidão infinita.

Aos professores que conheci durante as aulas da pós-graduação e pela postura de educadores abertos e prontos a ajudar e apoiar. Obrigada, professora Diana Pessoa de Barros, pela chance de escrever meu primeiro artigo e pela chance de aprendizado em seu curso de Semiótica.

Agradeço à Universidade de São Paulo, pela oportunidade de realizar este projeto, e à CAPES, pelo apoio através da bolsa de estudos. 
"Definitions belong to the definers, not the defined."

“Definições pertencem aos definidores, não aos definidos.”

Toni Morrison, no livro "Beloved" ("Amada”) 


\section{RESUMO}

ALMEIDA, C. L. A construção de identidade do aluno disléxico no ambiente de ensino e aprendizagem da língua inglesa. Dissertação (Mestrado). Faculdade Filosofia, Letras e Ciências Humanas, Universidade de São Paulo, 2017.

A dislexia é um transtorno genético, hereditário e de origem neurobiológica que compromete a capacidade de escrita e de leitura em graus que variam de indivíduo para indivíduo. As dificuldades iniciam-se já no período de alfabetização e acompanham o disléxico por toda a sua vida, uma vez que há tratamento, mas não cura. Entre os vários sintomas, está a dificuldade em aprender uma segunda língua. Tendo em vista que a língua inglesa é uma exigência escolar e, muito frequentemente, profissional, há uma grande necessidade de compreensão das questões que envolvem a aprendizagem do idioma e o portador de dislexia. Este trabalho trata da construção de identidade - como imagem de si - do aluno disléxico no ambiente de ensino e aprendizagem da língua inglesa; trata de como suas dificuldades, a postura das instituições de ensino, educadores e família agem e influenciam a maneira como ele se enxerga e age nesse contexto. Este estudo é realizado por meio de entrevistas semiestruturadas cujas análises foram feitas tendo como base a semiótica francesa. A entrevista cobre a vida escolar regular assim como a experiência do disléxico com a língua inglesa, pois o interesse deste trabalho é ter uma visão ampla da trajetória desse sujeito e não somente um recorte de um momento de sua vida. Os resultados revelam que o diagnóstico, acompanhado de uma aceitação interna do mesmo, a dinâmica de relacionamento do disléxico com a escola e os professores e o apoio familiar são fatores que ajudam a moldar como o disléxico vê a si mesmo e como enfrenta suas dificuldades com a língua inglesa. O texto é dividido em seis capítulos, introdução e conclusão. A introdução busca dar uma visão do caminho percorrido no entendimento da dislexia, desde a era vitoriana até os dias atuais. O capítulo um discorre rapidamente sobre a metodologia. O capítulo dois analisa as entrevistas de modo descomplicado, tendo como objetivo manter uma linguagem clara e acessível a todos os leitores. $O$ capítulo três trata da semiótica das paixões e as relações entre as modalidades e as modalizações. O capítulo quatro traz algumas considerações sobre como auxiliar o disléxico em sala de aula de ensino de língua inglesa. O capítulo cinco focaliza nos 
estereótipos e, finalmente, o capítulo seis, que analisa o percurso do reconhecimento de si do disléxico baseado na obra de Paul Ricoeur.

Palavras-chave: Dislexia. Língua inglesa. Semiótica discursiva. Identidade narrativa. Ensino-aprendizagem. 


\section{ABSTRACT}

ALMEIDA, C. L. The construction of the identity of the dyslexic student in the learning and teaching environment of the English language. Dissertação (Mestrado). Faculdade Filosofia, Letras e Ciências Humanas, Universidade de São Paulo, 2017.

Dyslexia is a genetic, hereditary and neurobiological disorder that compromises the ability to write and read in degrees that vary from an individual to another. The difficulties begin in the phase of literacy acquisition and accompany the dyslexic throughout his life, since there is treatment, but not a cure. Among the various symptoms is the difficulty in learning a second language. Given that English is a school requirement and, very often, a professional requirement, there is a great need to understand the issues involved in language learning and dyslexia. This work deals with the construction of dyslexic student identity - identity as the image of the self - in the teaching and learning environment of the English language; It deals with how its difficulties, the posture of educational institutions, educators and family act and influence the way in which the dyslexic learner sees himself/herself and acts within that context. This study was carried out by means of semi-structured interviews analyzed within the framework of Greimasian semiotics. The interview cover regular school life as well as the dyslexic experience with the English language, since the interest of this work is to have a broader view of the individual's trajectory and not only a cross section of a moment of his life. The results reveal that the diagnosis, accompanied by internal acceptance of such diagnosis, the dynamics of the dyslexic relationship with the school and the teachers as well as family support are factors that help shape how the dyslexic sees himself/herself and how he/she faces the difficulties with the English language. The text is divided into six chapters, introduction and conclusion. The introduction seeks to give insight into the path taken in the understanding of dyslexia, from the Victorian era to the present day. Ghapter one is on the methodology used. Chapter two analyzes the interviews in an uncomplicated way, aiming at keeping the language clear and accessible to all readers. Chapter three deals with the semiotics of passions and the relations between modalities and modalizations. Chapter four brings some considerations on 
how to assist the dyslexic in the classroom. Chapter five focuses on stereotypes and, finally, chapter six, which analyzes the path of self-recognition of the dyslexic based on the work of Paul Ricoeur.

Keywords: Dyslexia. English language. Discursive semiotics. Narrative identity. Teaching-learning. 


\section{SUMÁRIO}

INTRODUÇÃO ................................................................................................14

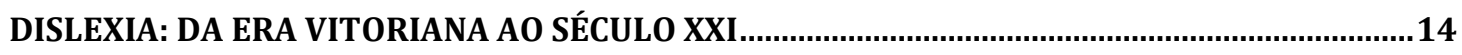

A ESCOLA E A IMPORTÂNCIA DO SEU POSICIONAMENTO EM RELAÇÃO AO DISLÉXICO E SEU

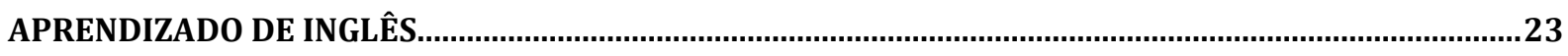

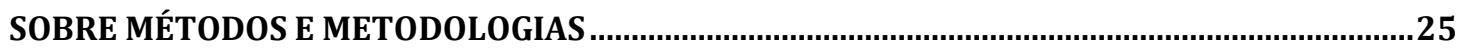

GLOBALIZAÇÃO, LETRAMENTO CRÍTICO E PRÁTICA DA LÍNGUA ............................................28

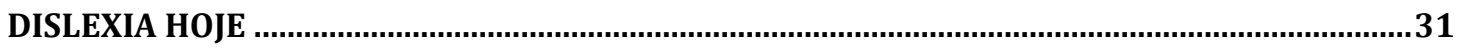

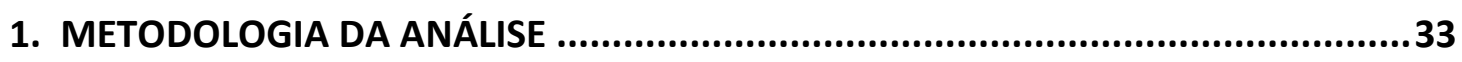

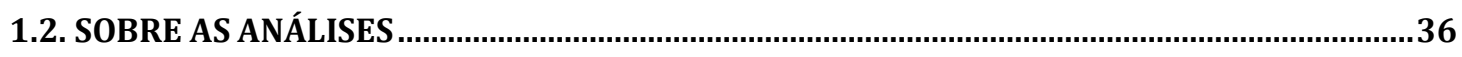

1.3. JUNÇÃO

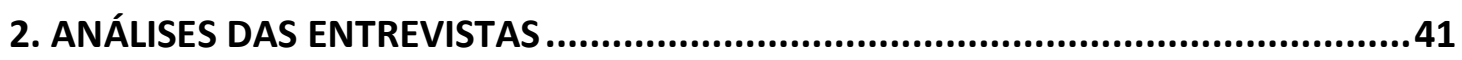

2.1. IVANA

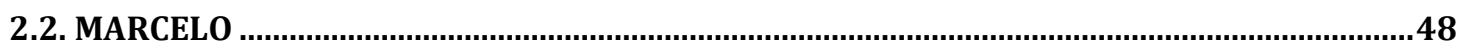

2.3. TIAGO

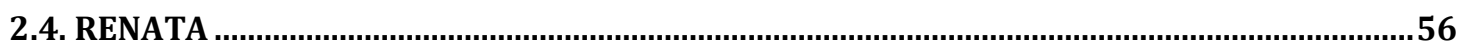

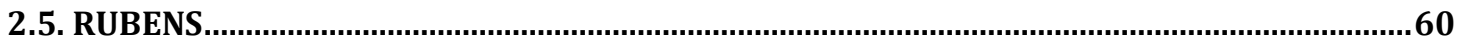

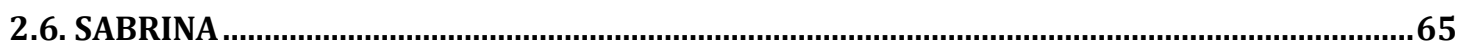

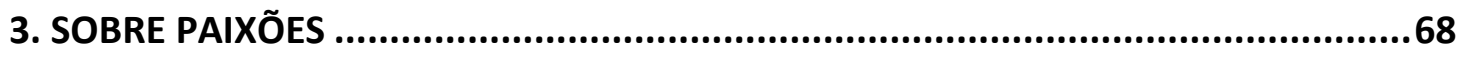

3.1. 0 DISLÉXICO E A LÍNGUA INGLESA - AS PAIXõES ENVOLVIDAS.........................................68

3.2. A FRUSTRAÇÃO 


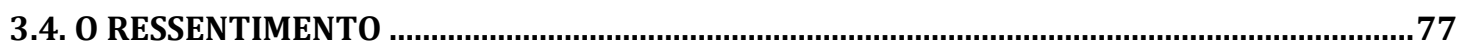

3.5. O MEDO E O PÂNICO ...........................................................................................................81

3.6. QUANDO CULPA E VERGONHA SE MISTURAM ...............................................................82

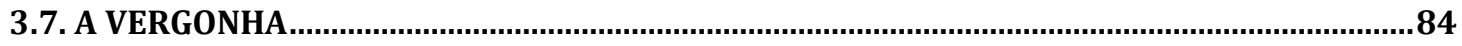

3.8. VISÃO GERAL DAS ENTREVISTAS ................................................................................87

4. CONSIDERAÇÕES SOBRE COMO AUXILIAR O DISLÉXICO NO AMBIENTE DE

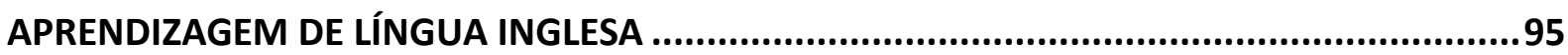

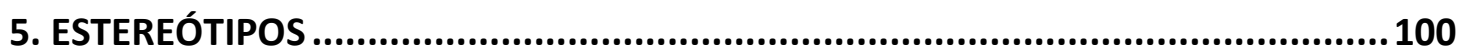

5.1. “SERÁ QUE SOU BURRO?” - O IMPACTO DO ESTEREÓTIPO ............................................... 100

5.2. LETRAS TROCADAS, PEQUENOS SABERES E SUBTERFÚGIOS ........................................... 106

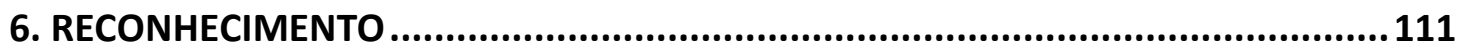

6.1. "RECONHECI-ME COMO DISLÉXICO" ...................................................................... 111

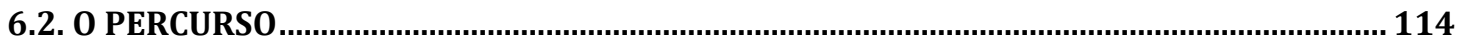

6.3. O SUJEITO CAPAZ ................................................................................................................. 118

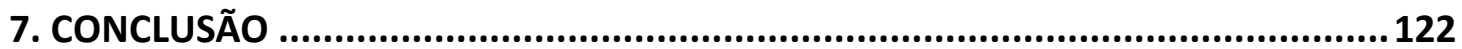

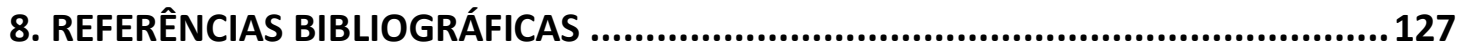

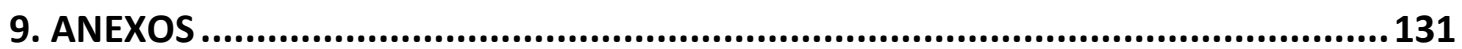

ANEXO A: OS DIREITOS DOS DISLÉXICOS............................................................................ 131

ANEXO B: TRANSCRIÇÃO - IVANA................................................................................................ 133

ANEXO C: TRANSCRIÇÃO - MARCELO .................................................................................... 136

ANEXO D: TRANSCRIÇÃO - RENATA............................................................................... 138 
ANEXO E: TRANSCRIÇÃO - RUBENS..

ANEXO F: TRANSCRIÇÃO - TIAGO 


\section{INTRODUÇÃO}

DISLEXIA: DA ERA VITORIANA AO SÉCULO XXI

Crianças inteligentes, motivadas, provenientes de famílias escolarizadas e com acesso a bons professores fazem parte dos primeiros relatos de médicos, ao final do século XIX na Inglaterra, que afirmam que essas crianças, apesar de brilhantes, não conseguiam aprender a ler. Abaixo, a descrição no British Medical Journal, feita pelo Dr. W. Pringle Morgan, de Seaford, em 1896, a respeito de Percy F., de 14 anos:

Ele sempre foi um menino brilhante e inteligente, rápido nos jogos, e em
nenhum aspecto inferior aos colegas da mesma idade. Sua grande
dificuldade foi - e permanece - sua incapacidade de ler. Está na escola ou
sob a supervisão de alguém desde os 7 anos, e muito tem sido feito para
ensiná-lo a ler, mas, apesar do treinamento trabalhoso e persistente, é só
com dificuldade que ele consegue soletrar palavras de uma sílaba... [...] Eu
poderia acrescentar que o menino é esperto e de inteligência média em
seus diálogos. Seus olhos são normais...e sua visão é boa. O professor que
lhe ensinou durante alguns anos diz que ele seria o menino mais bem
preparado da escola se o ensino fosse totalmente oral (SHAYWITZ, 2006,
p.24).

De acordo com Shaywitz (2006), Morgan foi capaz de apontar as características básicas do que hoje se chama dislexia de desenvolvimento e o primeiro médico a usar a expressão cegueira verbal, já que dislexia não era um termo usual na época. No entanto, a observação de pessoas inteligentes e com boa visão que não eram capazes de ler já havia sido feita em 1676, porém, em indivíduos com algum dano cerebral. O Dr. Johann Schmidt relata a história de seu paciente, Nicolas Cambier, de 65 anos, que ficou incapacitado de ler após um derrame. Tumores ou lesões também foram percebidos como causadores de problemas de leitura, daí o termo alexia adquirida. Em 1872, o neurologista britânico Sir William Broadbent aponta um caso desse tipo ao relatar um paciente com dificuldades para referir-se a objetos comuns e que afirmava ver as palavras, mas ser incapaz de as entender. Adolf Kussmaul, em 1877, constatou a presença de uma cegueira em relação ao texto, mesmo com visão, intelecto e fala absolutamente normais e foi responsável por cunhar o termo wortblindheit (cegueira verbal), ou, o que hoje é conhecido como dislexia. Ele restringiu wortblindheit a uma situação 
isolada de dificuldade de reconhecimento de palavras e leitura de textos que não afeta o campo da oralidade. Em 1887, Rudolf Berlin, em sua monografia Art Der Wortblindheit (Um caso particular de cegueira verbal), na qual observou 6 casos, por 20 anos, de adultos que não conseguiam mais ler depois de uma lesão, chamou de dislexia a cegueira verbal presente nesses casos e abriu caminho para a compreensão do problema: denominou de alexia adquirida a presença de total incapacidade de leitura e de dislexia a presença de um problema fosse parcial, com uma "grande dificuldade em interpretar símbolos escritos ou impressos [...]" (p.26); Berlin também decidiu por incluir a dislexia no grupo de distúrbios de linguagem chamado de afasia'.

Shaywitz informa que em 1863 Rudolf Berlin descreve um paciente decidido a parar de trabalhar pelo fato de não mais conseguir ler. O que chamou atenção foi o fato de que a dificuldade de visão não era causada por falta de conforto ou dor. De acordo com o paciente, "as letras não ficavam enevoadas ou obscuras simplesmente não conseguia mais ler... Nem seus olhos nem os músculos oculares demonstravam qualquer anormalidade mesmo sob o mais cuidadoso dos exames" (2006, p.26). Somados a histórias como essa, outros pacientes diziam ser capazes de ler números em fontes pequenas, mas incapazes de ler palavras, mesmo em fontes maiores. Tornou-se comum, por isso, que casos de cegueira verbal fossem encaminhados a oftalmologistas, hábito que ainda vemos hoje em dia - ainda prevalece o mito de que disléxicos enxergam mal. E foi exatamente o relato de um oftalmologista, James Hinshelwood, de Glasgow, em 1895, que "serviu de catalisador para o artigo subsequente de Morgan, o qual descrevia a cegueira verbal congênita" (2006, p.26). O artigo saiu no periódico The Lancet e descrevia os problemas de um paciente de 58 anos, professor de francês e alemão e que em uma manhã descobriu que

não conseguia ler um exercício de francês que um aluno the dera para corrigir. No dia anterior, ele havia lido e corrigido os exercícios normalmente. [...] Ao examinar sua acuidade visual com os caracteres tipográficos utilizados para testes, descobri que ele não conseguia ler nem as letras nos maiores tipos disponíveis. [...] não conseguia me dizer o que

\footnotetext{
${ }^{1}$ A afasia é uma deterioração da função da linguagem falada e escrita, após ter sido adquirida de maneira normal e sem déficit intelectual correlativo. É caracterizada pela dificuldade em nomear pessoas e objetos. [...] Afasia de Werneck: fala fluente, ou logorreia, que não faz sentido para o ouvinte, embora a pessoa acredite estar falando corretamente; Afasia de Broca: o paciente tem dificuldades para falar porque lhe faltam as palavras; Afasia global: perda total da capacidade de fala, compreensão, leitura e escrita (www.infoescola.com)
} 
elas significavam. Descobri, mais tarde, ao examiná-lo com números, que ele não tinha a menor dificuldade em lê-los, sem cometer qualquer espécie de erro (SHAYWITZ, 2006, p.27).

Morgan percebeu as semelhanças entre os sintomas de Percy e o professor de francês e alemão que, apesar de terem históricos diferentes, apresentavam a mesma sintomatologia da cegueira verbal. Percy nunca aprendeu a ler, enquanto o professor, em dado momento da vida e por razões desconhecidas, perdeu a habilidade de leitura. É assim que Morgan chega à cegueira verbal congênita e a seu importante artigo de 1896, que é um momento crucial no entendimento das dificuldades de leitura nas crianças, que "pode passar despercebida por um longo período. A forma congênita é mais circunscrita, afetando primeiramente a leitura, às vezes a linguagem falada, mas nunca a força muscular"² (SHAYWITZ, 2006, p.27).

A partir desse momento, tudo foi uma questão de tempo para que cada vez mais casos de cegueira verbal congênita fossem diagnosticados, principalmente por oftalmologistas tanto da Grã-Bretanha como da Europa, América do Sul e Estados Unidos. "Mas nenhum deles abarcou ou entendeu a significação do problema tão inteiramente quanto Hinshelwood, nem alguém foi tão dedicado quanto ele no que diz respeito a divulgar o problema entre seus colegas" (SHAYWITZ, 2006, p.28). Histórias de crianças, adolescentes e adultos inteligentes, de memória extraordinária, que conseguiam ser bem-sucedidos em várias áreas, mas que eram barrados em seu aprendizado quando chegavam ao campo da leitura foram sendo registradas. Hinshelwood lutou para que suas descobertas chegassem ao público e seus artigos e palestras buscavam conscientizar médicos para que o distúrbio fosse diagnosticado com mais facilidade; seus dados eram oriundos de fatos clínicos, frutos de seu interesse pela cegueira verbal congênita, não meras observações aleatórias. Com seus colegas, estava preocupado "com as implicações do distúrbio: o quanto ele durava; sua frequência, que grupos de crianças corriam maior risco; que tratamento era melhor" (SHAYWITZ, 2006, p.29).

Nessa época, o cirurgião ocular E. Treacher Collins relatou suas conclusões sob os sintomas mais importantes do distúrbio

\footnotetext{
${ }^{2}$ A autora refere-se à força muscular pelo fato de que pacientes com cegueira adquirida por alguma lesão, derrame ou tumor, têm a área direita do cérebro afetada, o que causa problemas em várias funções. Experimentam também, além dos problemas de leitura, fraqueza muscular no lado direito do corpo, que causam dificuldades de pronúncia e nomeação de objetos.
} 
eram frequentemente negligenciados, sendo classificados como mera burrice, ou algum erro de refração, o que prejudicava muito o indivíduo, que era em geral culpado, intimidado e ridicularizado por um defeito pelo qual não tinha culpa, mas sim o azar de possuir (SHAYWITZ, 2006, p.29).

Já nesse período, médicos percebiam o profundo impacto da dislexia na família, assim como a importância do apoio familiar; Hinshelwood defendia a necessidade de um diagnóstico precoce e solicitava às escolas que tivessem procedimentos de identificação de cegueira verbal baseados em fatos científicos para que as crianças fossem atendidas corretamente. Ele percebia a falta de atenção dada a alunos com cegueira verbal dentro de um sistema educacional que dava pouca atenção à questão. Finalmente, defendia a educação especial, sugerindo aulas particulares curtas, mas frequentes, e que o aluno não fosse forçado a ler em voz alta na frente dos colegas - pontos essenciais com os quais lutamos até hoje.

Em 1925, os termos dislexia específica ou distúrbio específico de leitura, propostos pelo médico americano Dr. Samuel Orton $^{3}$, tornaram-se mais usados do que dislexia congênita, por exemplo, por serem mais específicos. Tais termos referiam-se a um distúrbio de aprendizagem de leitura com causa neurológica (ALVES et al., 2011, p.29).

Embora existam tantos outros nomes cuja contribuição ajudou a construir o caminho para que chegássemos ao que entendemos hoje por dislexia, achamos mais produtivo focar nessa fase na qual se deu o entendimento da cegueira verbal cognitiva, que facilita a compreensão da condição e das implicações na vida do sujeito que precisa conviver com ela. Por isso, damos um salto para os dias de hoje para o que a Associação Brasileira de Dislexia (ABD), criada em $1983^{4}$, entende por dislexia:

A dislexia do desenvolvimento é considerada um transtorno específico de linguagem, de origem neurobiológica, caracterizada por dificuldades no reconhecimento preciso e/ou fluente da palavra, na habilidade de

\footnotetext{
${ }^{3}$ A abordagem Orton-Gillingham. Uma abordagem instrucional para uso com pessoas que possuem dificuldade com leitura, soletração e escrita associados à dislexia. É mais entendido e praticado como uma abordagem, não um método, programa, sistema ou técnica. Nas mãos de um instrutor experiente e bem treinado, é uma ferramenta poderosa de extensão, profundidade e flexibilidade excepcionais. O nome é dado por basear-se nos trabalhos do Dr. Samuel T. Orton, neuropsiquiatra e patologista e de Ana Gilllingham, educadora talentosa e psicóloga (tradução nossa) Fonte: www.ortonacademy.org/approach.php

${ }^{4} \mathrm{http}: / /$ www2.camara.sp.gov.br/projetos/2013/00/00/0H/SQ/00000HSQ4.pdf
} 
decodificação e em soletração. Essas dificuldades normalmente resultam de um deficit no componente fonológico de linguagem e são inesperados em relação à idade e outras habilidades cognitivas. (Definição adotada pela IDA - International Dyslexia Association, em 2002, Essa também é a definição usada pelo National Institute of Child Health and Human Development NICHD) (“Associação Brasileira de Dislexia", 2015).

Abaixo, um quadro com os principais sintomas da dislexia na pré-escola, na idade escolar e na fase adulta:

\begin{tabular}{|c|c|}
\hline Pré-escola & $\begin{array}{l}\text { Nota-se um fraco desenvolvimento da } \\
\text { atenção, imaturidade, atraso na fala, no } \\
\text { desenvolvimento visual e na dificuldade para } \\
\text { rimas. Há fraco desenvolvimento da } \\
\text { coordenação motora, dificuldade com } \\
\text { quebra-cabeças, falta de interesse com livros } \\
\text { e impressos. }\end{array}$ \\
\hline Idade escolar & $\begin{array}{l}\text { Caracteriza-se por dificuldades linguísticas, } \\
\text { como análise e síntese dos sons de } \\
\text { palavras, pobreza no reconhecimento de } \\
\text { rimas e aliteração. Apresentam-se } \\
\text { desatentos, dispersos, desorganizados, com } \\
\text { alteração de coordenação motora fina e } \\
\text { grossa, com dificuldade quanto à } \\
\text { lateralidade, vocabulário pobre, alteração de } \\
\text { memória de curto prazo, dificuldade de } \\
\text { leitura, na capacidade de copiar, em cálculos } \\
\text { matemáticos, obtendo melhor desempenho } \\
\text { em provas orais. }\end{array}$ \\
\hline Fase adulta & $\begin{array}{l}\text { Mantém dificuldade na leitura e escrita, } \\
\text { principalmente para soletrar; memória } \\
\text { imediata prejudicada; disnomias }{ }^{5} \text {; }\end{array}$ \\
\hline
\end{tabular}

5 Disnomia é uma incapacidade em nomear pessoas ou objectos, mesmo quando estes são completamente percebidos e compreendidos, ou seja, mesmo quando a pessoa sabe como se chama determinado objeto. A pessoa com disnomia é perfeitamente capaz de descrever o objecto e causa, mas não consegue lembrar-se do seu nome, mesmo quando se trata de algo que faça parte do seu quotidiano como lápis ou borracha ou pessoas com as quais convive diariamente, como os colegas de escola ou os professores. A disnomia é comumente associada ao hemisfério dominante, 


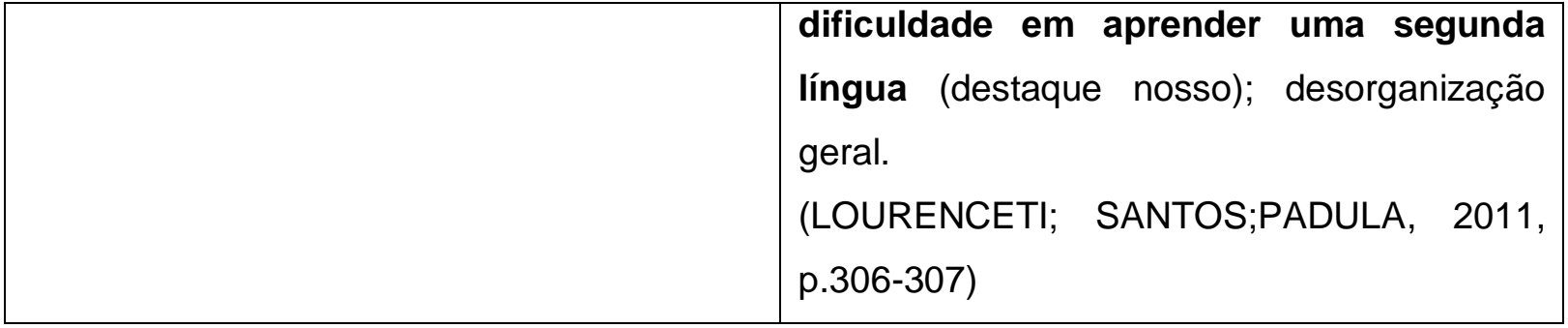

À dislexia podem-se somar outros transtornos, o que gera um quadro de comorbidade, ou seja, a simultaneidade de condições em um indivíduo. Disléxicos podem - não obrigatoriamente - apresentar problemas em relação à escrita (disortografia e disgrafia), discalculia (informalmente conhecida como dislexia na matemática) e TDAH (Transtorno de Déficit de Atenção e Hiperatividade) e que, se não diagnosticados corretamente, acabam interferindo e mascarando o problema.

Daniel Britton, um designer do Reino Unido diagnosticado com dislexia em seu último ano de faculdade, cansado de tentar explicar a seus professores e colegas como se sentia quando precisava ler, criou uma fonte cujo propósito é mostrar a não disléxicos o processo de leitura para quem tem o transtorno:

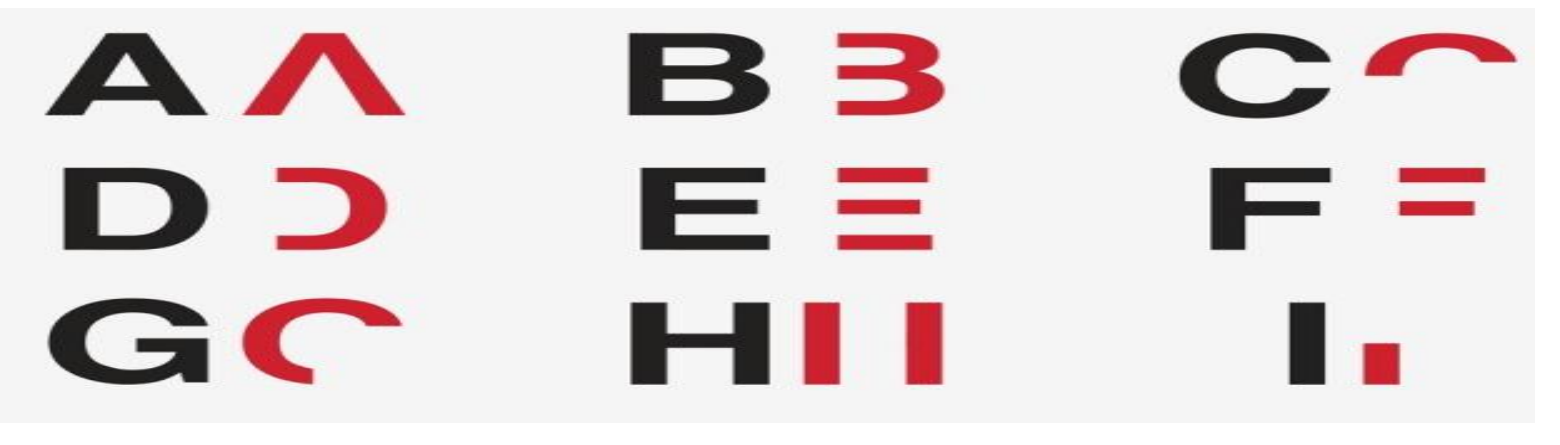

(Fonte: http://www.smh.com.au/technology/sci-tech/designer-daniel-britton-creates-font-to-show-whatits-like-to-have-dyslexia-20150619-ghs5tn.html)

Abaixo, um texto escrito com essa fonte e que diz: "essa tipografia não foi feita para recriar o que seria ler se você fosse disléxico, ela foi feita para simular a sensação de ler com dislexia através da diminuição da velocidade do leitor ao nível da velocidade com a qual alguém com dislexia leria" (tradução nossa). Em inglês: "this typography is not designed to recreate what it would be like to read if you were

nomeadamente nas zonas da linguagem, no lobo temporal. Pode ser uma característica presente nas pessoas com dislexia e é, provavelmente, a anomalia da linguagem mais frequente na Doença de Alzheimer. Fonte: http://educamais.com/disnomia/ 
dyslexic, it is designated to simulate the feeling with dyslexia by slowing down the reading time of the viewer down to the speed of which someone with dyslexia would read".

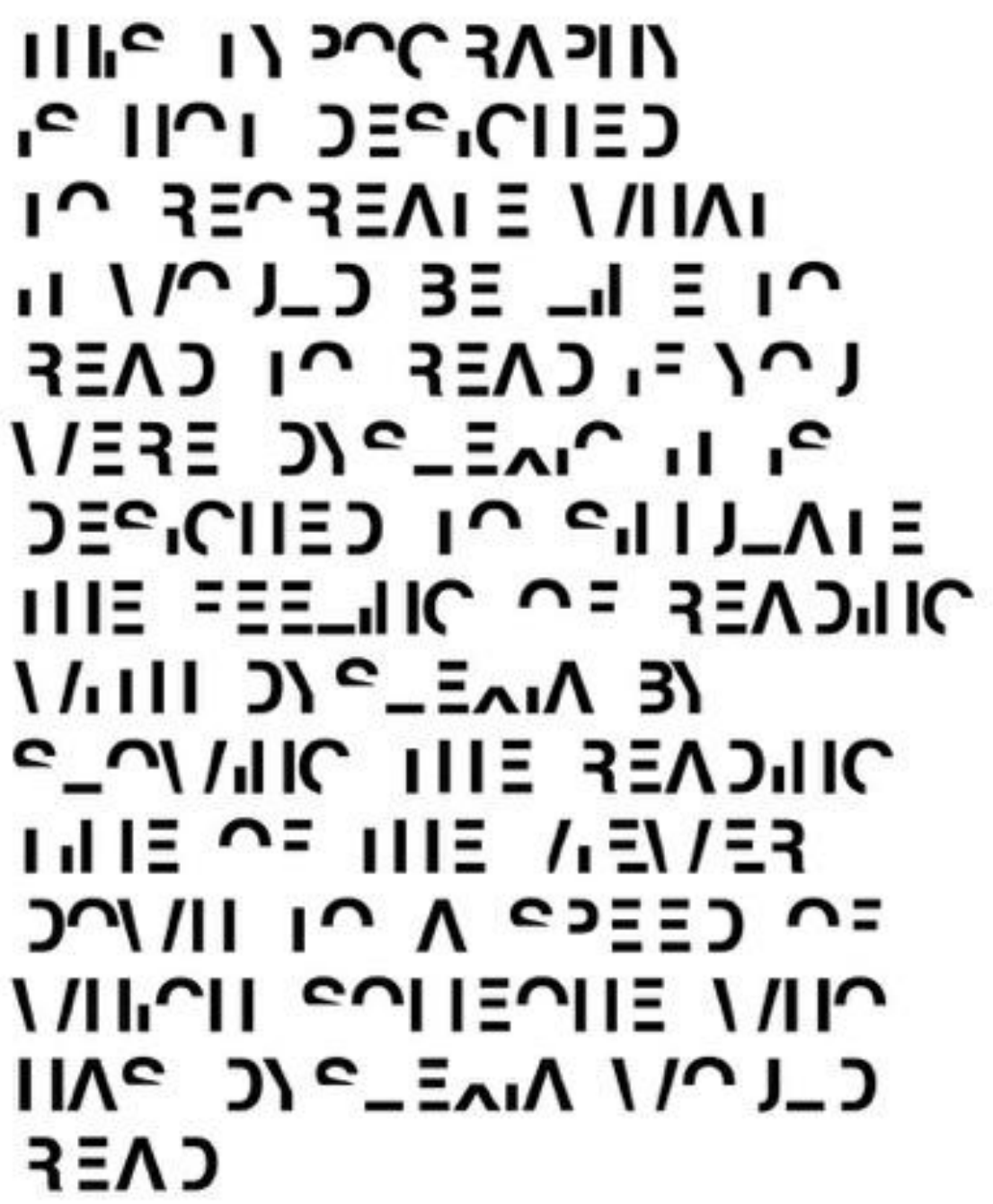

(Fonte: http://www.smh.com.au/technology/sci-tech/designer-daniel-britton-creates-font-to-show-whatits-like-to-have-dyslexia-20150619-ghs5tn.html)

Christian Boer, também designer, criou uma fonte específica para disléxicos e disponível para ser baixada em seu site - dyslexiefont.com. Christian levou em consideração o fato de que disléxicos confundem as letras sem mesmo perceberem, o que se dá por causa da similaridade entre elas e pela proximidade com que ficam uma das outras. A Dyslexie Font possui uma distância maior entre as letras e entre as palavras, assim como letras maiúsculas e sinais de pontuação mais fortes e marcados para que o disléxico identifique o início de frases mais facilmente. É uma 
letra mais limpa, que busca ao máximo a redução de semelhança, com abertura maior nos espaços e uma base mais pesada, buscando na gravidade a justificativa de que, assim, elas não viram de cabeça para baixo. Veja um texto usando essa fonte:

\section{Graphic designer Christian Boer} has dyslexia himself and designed the font to improve his reading life. People with dyslexia often swap, rotate and flip letters without noticing. The problem is that some letters are too similar to each other. Dyslexie font is designed so that every letter is unique in its own form. This counters the rotation, flipping and reversal of the letters.

\section{(Fonte: https://www.dyslexiefont.com/en/dyslexie-font/)}

Pode-se concluir, portanto, que a vida de um disléxico é, no mínimo, repleta de desafios, independentemente de sua idade. Não é difícil imaginar a agonia e o desespero de um disléxico em uma aula de português ao ser chamado para ler em voz alta ou para responder uma pergunta de interpretação de texto - quando, provavelmente, nem conseguiu chegar à metade da leitura dada. A dislexia é um desafio na língua materna e seu peso pode ser ainda maior quando o aluno se vê diante da necessidade de aprender uma segunda língua. Se ele já se sente perdido ao ler um texto na própria língua, quando essa leitura é exigida em outro idioma o 
problema é duplicado, o que explica que aprender uma segunda língua esteja entre um dos sintomas do transtorno.

Este trabalho olha para a dislexia dentro do contexto de ensino de inglês, mas sem ignorar o contexto escolar geral do disléxico, assim como sua relação com professores, outras matérias e até outros idiomas. O aluno é parte de uma rede e não é eficiente uma análise que o recorte de um ambiente que se organiza e evolui interligado a vários fatores e situações. O inglês é um braço da vida escolar de um disléxico e depende de uma construção afetiva, emocional e pedagógica prévia, que pode tanto ajudá-lo em sua vida acadêmica quanto destruir para sempre qualquer desejo de aventurar-se pelo mundo do idioma inglês.

Como professora de inglês há mais de vinte anos, vejo em minhas mãos a responsabilidade de ajudar qualquer um que faça parte da rede de relações de um disléxico a entender, pelo olhar dele mesmo, as dificuldades, medos, anseios e desejos do portador de dislexia em sua aventura pelo mundo escolar, mas principalmente, pelo mundo da língua inglesa. 


\section{A ESCOLA E A IMPORTÂNCIA DO SEU POSICIONAMENTO EM RELAÇÃO AO DISLÉXICO E SEU APRENDIZADO DE INGLÊS}

Qual o papel da escola? Saviani diz que ela "existe, pois, para propiciar a aquisição dos instrumentos que possibilitem o acesso ao saber elaborado (ciência), bem como o próprio acesso aos rudimentos desse saber" (2013, p.14). Levando-se em consideração esse pensamento, torna-se de extrema importância que analisemos como - e se - a escola tem propiciado a alunos com dificuldades de aprendizagem, mais especificamente a disléxicos, as ferramentas necessárias para que consigam acessar, de forma clara, prática e produtiva, o saber que lhes é apresentado. Produtiva, especialmente por entender-se que até mais do que em outras áreas, no campo de uma segunda língua a produtividade é o objetivo principal, senão o único. De que vale ao aluno receber informação a respeito de uma língua se ele não é instruído de forma eficaz quanto ao seu uso de forma ampla? É importante que levemos em consideração que o aprendizado de uma língua envolve não só gramática, normas e regras, como também o desenvolvimento de uma capacidade de inserir-se em outra cultura para entendê-la, processo que, na busca por crescimento pessoal, leva tanto ao entendimento da cultura estudada quanto de si mesmo. É uma interação com o ambiente de aprendizado, colegas, professores e, por que não, com o material didático e com o mundo. Norton e Toohey defendem que, para o aluno, a prática da língua é uma prática que vai além da comunicação, "é uma prática que constrói, e é construída, pela maneira pela qual os alunos entendem a si mesmos, seu contexto social, suas histórias e suas possibilidades para o futuro" (2004, p.1, tradução nossa). ${ }^{6}$

Outra questão importante e que deve ser olhada de perto é a referente ao desenvolvimento crítico, colocado por Monte Mor (2013) como uma das habilidades necessárias àquele que vive e participa de uma sociedade globalizada. Se é entendido que a aprendizagem satisfatória de uma segunda língua demanda pensamento crítico por parte do aprendiz, temos mais uma razão para considerarmos esse fator relevante dentro da análise da questão do disléxico. Quando em um ambiente que não Ihe propicia as condições, sejam elas pedagógicas ou emocionais, para uma aquisição eficaz do idioma, o portador de

\footnotetext{
6 "It is a practice that constructs, and is constructed by, the ways language learners understand themselves, their social surroundings, their histories, and their possibilities for the future".
} 
dislexia perderá a oportunidade de desenvolver a criticidade devida para que o idioma em questão seja futuramente integrante de sua vida - além de útil em termos práticos.

Dificuldade em aprender uma segunda língua é um sintoma da dislexia, mas a língua inglesa se mostra um obstáculo maior. Alves et al. explicam que:

Com relação à prevalência da dislexia, é muito importante considerar que ela pode variar de acordo com o sistema de escrita, ou seja, sistemas ortográficos mais irregulares, como o inglês e o francês, podem dificultar ainda mais o processo de aprendizagem da língua escrita do que sistemas um pouco menos opacos, como o italiano e o espanhol $(2011$, p.28)

Aprender, para o disléxico, é um grande desafio. Caminhar pelo universo de uma outra língua, portanto, é um desafio a mais, pois a luta com a própria língua já é desgastante o suficiente. Fica, por isso, nas mãos da escola, principalmente, a responsabilidade pela busca de estratégias que empoderem o aprender e aliviem o sofrimento emocional desse aluno envolto em um processo de aprendizagem cheio de obstáculos. 


\section{SOBRE MÉTODOS E METODOLOGIAS}

Uma consulta às listas de sintomas da dislexia deixa claro que grande parte deles envolve habilidades exigidas para um aprendizado eficiente de uma língua. Dificuldade em aprender o alfabeto, incorporar novo vocabulário, compreender e elaborar textos escritos e soletrar, citando somente algumas, são competências cruciais para o aprendizado da língua materna tanto quanto de uma segunda língua. Tendo em vista que a dislexia causa estresse emocional e traz obstáculos em um ambiente no qual o aluno usa seu próprio idioma, o que dizer do ambiente no qual esse aluno precisa lidar com outro - lembrando que ele não se sente confortável nem mesmo com o português?

Saviani escreve que "vê-se, assim, que para existir a escola não basta a existência do saber sistematizado. É necessário viabilizar as condições de sua transmissão e assimilação" (2013, p.17). O autor não trata especificamente do ensino de idiomas, mas da escola e seu papel perante o aluno. Porém, o conceito é profundo quando acreditamos que está no âmbito da responsabilidade da escola, seja qual for o conhecimento que pretende difundir, providenciar meios para que 0 aluno seja capacitado a apreender o conteúdo ao qual é exposto, mas, acima de tudo, desenvolver seus meios de aprender, "tendo claro que é o fim a atingir que determina os métodos e processos de ensino-aprendizagem" (2013, p.17). O autor cita o movimento da Escola Nova ${ }^{7}$, que reprovava a escola tradicional por esta ter deixado para trás os fins e transformado os conteúdos transmitidos em algo mecânico e vazio de sentido ao mesmo tempo em que também critica o movimento, que começou a " classificar toda transmissão de conteúdo como mecânica e todo

7 Escola Nova é um dos nomes dados a um movimento de renovação do ensino que foi especialmente forte na Europa, na América e no Brasil, na primeira metade do século XX. "Escola Ativa" ou "Escola Progressiva" são termos mais apropriados para descrever esse movimento que, apesar de muito criticado, ainda pode ter muitas ideias interessantes a nos oferecer. No Brasil, as ideias da Escola Nova foram introduzidas já em 1882 por Rui Barbosa (1849-1923). No século XX, vários educadores se destacaram, especialmente após a divulgação do Manifesto dos Pioneiros da Educação Nova, de 1932. Podemos mencionar Lourenço Filho (1897-1970) e Anísio Teixeira (19001971), grandes humanistas e nomes importantes de nossa história pedagógica.

Um conceito essencial do movimento aparece especialmente em Dewey. Para ele, as escolas deviam deixar de ser meros locais de transmissão de conhecimentos e tornar-se pequenas comunidades. Lourenço Filho nos fala sobre a escola que Dewey dirigia no final do século passado, na Universidade de Chicago: "As classes deixavam de ser locais onde os alunos estivessem sempre em silêncio, ou sem qualquer comunicação entre si, para se tornarem pequenas sociedades, que imprimissem nos alunos atitudes favoráveis ao trabalho em comunidade."

(http://www.educacional.com.br/glossariopedagogico/verbete.asp?idPubWiki=9577) 
mecanismo como anticriativo, assim como todo automatismo como negação da liberdade" (2013, p.17).

Este trabalho não visa a tratar da crise entre o movimento Escola Nova e escola tradicional, mas vimos nessa valiosa observação de Saviani uma oportunidade de lembrar que educar é uma tarefa que envolve várias facetas. Há uma metodologia mais eficiente? Se uma nova maneira de ensinar se torna padrão, devemos ignorar tudo o que já foi feito? É possível mesclar diferentes metodologias? O ensino da língua inglesa, por exemplo, já passou por várias fases e diferentes métodos, mas acreditamos ser primordial para a inclusão eficaz do disléxico que analisemos como ele é acolhido nas metodologias atuais e vigentes. É dever da instituição e do educador, seja qual for a linha adotada para o ensino da língua inglesa, que o aluno disléxico seja prioritariamente levado em consideração e que, quando necessário, mudanças e revisões sejam feitas para que a ele sejam propiciadas as devidas condições de aprendizado.

Kumaravadivelu (2013), tratando da educação do professor de língua inglesa dentro de uma sociedade globalizada, escreve sobre a perspectiva do pós-método (postmethod perspective), que é uma mudança do olhar do professor sobre si mesmo e seu modo de ensinar; coloca o professor como o iniciador de mudanças, profissional com postura reflexiva e capaz de buscar pelas soluções que julga mais corretas para as questões que encontra em sala de aula. Em uma palestra dada em um encontro de professores na Índia e promovido pelo British Council em seu canal no YouTube, Kumaravadivelu deixa claro que o pós-método não é "um método alternativo, mas uma alternativa para o método" (tradução nossa). O autor entende que a educação do professor de língua é ritualística e fragmentada, ficando distante das práticas de sala de aula. Ele acredita em um educador que transforma e propõe um novo olhar para, pelo menos, três pontos importantes:

Primeiro, é preciso fazer um movimento para sair da abordagem linear em direção a uma abordagem holística e cíclica, que habilita o professor a ver padrões e conexões. Segundo, sair do modelo de pura transmissão, orientado por informação, para um modelo de transformação, orientado por questionamentos, que capacita o educador a construir uma visão e novas versões para seus próprios modelos de ensino. Finalmente, necessita-se de uma troca de conceitos que se desloca do método e se direciona para o pós-método. 
Se tais propostas valem para o ensino da língua inglesa, mostram-se ainda mais significativas quando as levamos para o ensino de inglês para disléxicos. Cabe a cada professor entender seus alunos e buscar, pela reflexão, observação e análise, o que pode funcionar, sem que fique preso a metodologias impostas e dadas como eficientes pelo mercado, o que limita a possibilidade de mudança e abertura. "É nesse sentido crítico que a perspectiva do pós-método vai além do abandono da busca pelo melhor método em direção a uma redefinição fundamental do método em si, defendendo fortemente uma mudança de poder de teóricos para praticantes" (KUMARAVADIVELU, 2012, p.11, tradução nossa) ${ }^{8}$.

8 "It is in this critical sense that the postmethod perspective goes beyond the abandonment of the quest for a best method to a fundamental redefinition of method itself, strongly advocating a shift in power from theorizers to practitioners". 


\section{GLOBALIZAÇÃO, LETRAMENTO CRÍTICO E PRÁTICA DA LÍNGUA}

O estresse emocional pode ser um dos grandes inimigos do aluno disléxico. As dificuldades que enfrenta, seja por não ter sido diagnosticado e/ou por não entender as implicações do distúrbio ou por não receber as ferramentas necessárias que lhe garantam um aprendizado mais confortável e eficaz, trazem ansiedades, medos, insegurança e até revolta. O aluno evita situações nas quais terá que ler, sente-se inferior, incapaz e pode até mesmo desenvolver comportamentos de oposição à autoridade, explica Lénia Carvalhais no site "Learning Disabilities Worldwide". Segundo a autora, estudos "comprovam que as crianças com baixa autoestima revelam menor confiança, não respondem voluntariamente às questões em sala de aula e evitam novas situações de aprendizagem". Portanto, se a escola falha em buscar soluções para que o portador de dislexia tenha um desempenho satisfatório, pode-se criar nesse aluno uma objeção à língua que pode comprometer severamente seu futuro.

A globalização é um fenômeno social, político, cultural e econômico que não pode ser negado - deve ser criticamente analisado, mas não ignorado - e que tem provocado mudanças em paradigmas em todos os mercados e áreas, incluindo educação. Suarez-Orozco e Qin-Hillard (2004) lembram que a nossa era é definida por esse fenômeno. Apontam também alguns de seus paradoxos, como o domínio da diferença e da complexidade. Sobre a diferença, que vem mudando a forma de como identidade e cultura são vividas, escrevem:

Administrar a diferença está tornando-se um dos maiores desafios para países multiculturais. Da França para a Suécia, do Brasil à Bolívia, da Indonésia à Malásia, o trabalho de administrar a diferença pede por uma nova agenda educacional. Crianças que crescem nesse e em outros ambientes estão mais suscetíveis do que qualquer outra geração na história da humanidade a enfrentar uma vida de trabalho e ligações, de amor e convivência com outros de contexto nacional, linguístico, religioso e racial diferentes. Eles serão desafiados a se engajar e trabalhar através da competição e contraste de modelos, tais como afinidade, gênero, língua (monolíngues e multilíngues) e as complicadas relações entre raça, etnia e 
desigualdade, de novas formas (SUARÉZ-OROZCO, QIN-HILLARD, 2004, p.4, tradução nossa) $)^{9}$.

Os autores também afirmam que a globalização gera complexidade e os indivíduos participantes desse novo modo de viver precisam possuir certas habilidades, dentre elas a capacidade de analisar e resolver problemas em face de uma multiplicidade de ideias, perspectivas e pontos de vista, que exige pessoas "cognitivamente flexíveis, culturalmente sofisticadas e capazes de trabalhar de modo colaborativo em grupos formados por indivíduos diversos" (2004, p.6, tradução nossa) ${ }^{10}$.

Mas como esses levantamentos se ligam ao disléxico? Intrinsecamente conectado às características do indivíduo globalizado apontadas por Suaréz-Orozco e Qin Hillard está o conceito de letramento crítico levantado por Monte Mor, já mencionado anteriormente, que escreve que "nos recentes estudos sobre letramento, a questão da crítica se renova ao ser abordada por uma perspectiva que a relaciona à linguagem como uma prática social" (2013, p.39). Um dos aspectos do letramento crítico levantado por Luke e Freebody (1997, p.213) e citados por Monte Mor refere-se ao fato de que "ler e escrever são atividades sociais" (2013, p.42) e que, nesse caso, são ferramentas de compreensão de que somos "nós" e de quem são "os outros".

Monte Mor menciona a melhora na alfabetização nas últimas décadas, mas ressalta um problema que ainda precisamos vencer: os analfabetos funcionais, ou seja, indivíduos que se enquadram em um contexto de uso muito restrito da língua; um conceito que "desconsidera/não prioriza a prática social da linguagem" (2013, p.32). Um indivíduo nessa posição não terá oportunidades iguais e terá sua participação social, como aluno e como cidadão, drasticamente reduzida.

\footnotetext{
9 "Managing difference is becoming one of the greatest challenges to multicultural countries. From France to Sweden, Brazil to Bolivia, Indonesia to Malaysia, the work of managing difference calls forth a new educational agenda. Children growing up in these and other settings are more likely than any other than in any previous generation in human story to face a life of working and networking, loving and living with others from different national, linguistic, religious, and racial backgrounds. They are challenged to engage and work through competing and contrasting models, such as kinship, gender, language (monolingual and multilingual), and the complicated relationships between race, ethnicity, and inequality, in new ways".

10 "...cognitively flexible, culturally sophisticated, and able to work collaboratively in groups made up of diverse individuals".
} 
...grande parte desses leitores pesquisados demonstra dificuldades na 'compreensão geral' do texto, na síntese do conteúdo de suas leituras (e também na construção de sentidos e visão crítica, conforme acrescentam os novos estudos de letramento), reforçando a percepção da necessidade de ampliação no enfoque crítico da educação/dos letramentos" (MONTE MOR, 2013, p.32).

Portanto, em um esforço de trazer tais apontamentos à realidade de vida do disléxico, entendemos que todas as demandas do mundo globalizado e a importantíssima noção de letramento crítico são aspectos profundamente relevantes no percurso social do indivíduo portador de dislexia. Quando preterido em um ambiente de ensino de língua inglesa, o disléxico - quando não abandona totalmente a ideia de um dia aprender o idioma - é também preterido nesse mundo globalizado. Sua inclusão e chances de infiltrar-se nesse universo serão seriamente afetados. Ser um analfabeto funcional em um segundo idioma o impedirá de avançar, desenvolver habilidades críticas e participar de uma sociedade que cobra dele tais competências. 


\section{DISLEXIA HOJE}

Luciana Mendonça Alves, Renata Mousinho e Simone Aparecida Capellini são as organizadoras da série de três volumes intitulada "Dislexia, novos temas, novas perspectivas" que providenciam um excelente panorama sobre diversos aspectos do distúrbio. Os livros tratam de temas como identificação, prevenção, intervenções, avaliações, comorbidades, processamento fonológico, entre outros, com uma série de artigos cuja análise de dados é de grande importância para quem deseja ter uma visão geral da dislexia.

Nos Estados Unidos houve um indiscutível desenvolvimento de metodologias de leitura - verdadeiros pacotes de atividades - que visam ajudar o aluno disléxico desde o início de sua vida escolar e que estão disponíveis para professores e instituições de ensino. "The Orthon Gillingham Multisensory Method", criado nos anos de 1930, é um deles. Há programas especiais de leitura em muitas escolas e testes padronizados que avaliam a eficiência de leitura dos alunos, como o "Test of Word Reading Efficiency (TOWRE).

\footnotetext{
O programa Read, Write \& Type Leanring System produzido pela Typing Fingers (RWT) oferece um ensino sistemático e explícito relativo às habilidades fonológicos básicas, enfatizando a escrita como um caminho para a leitura. [...] Usar o RWT, dizem os pesquisadores, resultaria em apenas 2 a $4 \%$ de crianças saindo da primeira série como leitores fracos (SHAYWITZ, 2006, p.209).
}

Apesar de os métodos fônico e multissensorial, mundialmente aceitos como os mais indicados para disléxicos, serem utilizados também no Brasil, não temos programas específicos nem banco de dados de atividades aos quais professores e escolas possam ter acesso. Como não temos um programa nacional que vise a um padrão de intervenção e ensino, as tentativas em direção a algo assim tendem a ser esforços pontuais pelo país.

No Brasil, as pesquisas mais recentes sobre a dislexia e língua inglesa abordam temas como ensino-aprendizagem, dificuldades enfrentadas pelo aluno, estratégias de ensino e função da linguagem que ainda não alcançaram de modo eficaz nem as escolas regulares nem os institutos de idioma. Flora Maria de Jesus trata dos conhecimentos do professor e métodos e estratégias de intervenção em "Dislexia e Língua Estrangeira - Inglês" (2015); Juliana Reichert Assunção Tonelli 
faz um estudo de caso e investiga as relações entre dificuldades de aprendizagem de leitura e escrita e aprendizagem de LI em "A "dislexia" e o ensino-aprendizagem da língua inglesa" (2012). Tonelli trata do tema nos seguintes artigos: "O trabalho docente e a inclusão: o caso da 'dislexia' nas aulas de inglês" (2014) analisa um conjunto de dados que consiste de atividades, descrição, diários de sala e transcrição de aula na análise do desenvolvimento profissional do professor em contexto de ensino a aluno disléxico" e "As possibilidades de aprendizagem e as capacidades de linguagem de um aluno 'disléxico' aprendiz de inglês" (2017) é um estudo de caso a partir do conceito de linguagem como atividade socialmente organizada. Nenhum dos trabalhos acima, no entanto, debruça-se sobre o nosso interesse: a construção identitária do disléxico no ambiente de ensino e aprendizagem da língua inglesa, fato que justifica esta pesquisa que busca também contribuir com enriquecimento da compreensão e das necessidades dos disléxicos. 


\section{METODOLOGIA DA ANÁLISE}

Um texto é composto de camadas que não são sempre apreendidas por todos os seus leitores, fato perceptível com um simples exercício de interpretação. Várias podem ser as razões: o nível da disposição do leitor em tentar desvendar essas camadas, dificuldades impostas pelo próprio texto ou barreiras culturais entre esse texto e seu leitor, em meio a tantas outras. Sejam quais forem as razões, a semiótica apresenta-se com a "intenção de tornar explícitos os mecanismos implícitos de estruturação e interpretação de texto" (RABELO, 2016), pois quer mostrar o que se esconde por trás dele. Mas antes de tratarmos de tais mecanismos, é relevante elucidar o que é o texto, objeto de estudo da semiótica.

[...] pode ser tanto um texto linguístico, indiferentemente oral ou escrito - uma poesia, um romance, um editorial de jornal, uma oração, um discurso político, um sermão, uma aula, uma conversa de criança -, quanto um texto visual ou gestual - uma aquarela, uma gravura, uma dança - ou, mais frequentemente, um texto sincrético de mais de uma expressão - uma história em quadrinhos, um filme, uma canção popular. (BARROS, 2011, p. 8).

Neste trabalho, nosso texto é a entrevista ${ }^{11}$. Feita por telefone ou via Skype, o entrevistado respondeu a perguntas sobre dislexia, escola e inglês. Em uma conversa desse tipo, algum nível de digressão é inevitável e esperado, pois tocamos em pontos sensíveis e não somos capazes de prever para onde cada pergunta levará, razão pela qual, apesar de as perguntas serem inicialmente as mesmas, cada entrevista percorreu seu próprio caminho e verteu em diferentes direções. Fugindo brevemente da semiótica francesa, queremos citar William B. Gomes, do Instituto de Psicologia da UFRGS, que explica que a entrevista é uma maneira de estudar a experiência consciente e que, dentre os vários modos de se entrevistar, "uma possibilidade é através de um roteiro flexível e aberto aos diferentes modos de reação do entrevistado" (1997, p.305). Ele sugere o mesmo protocolo que seguimos: gravação, transcrição e análise sistêmica e sistemática. Vale apontar que Gomes

\footnotetext{
11 Todos os entrevistados assinaram Termo de Consentimento. Os nomes são fictícios e foram apagadas todas as informações pessoais que pudessem comprometer o sigilo da identidade dos participantes.
} 
justifica esse método baseado na tradição da psicologia fenomenológica ${ }^{12}$ e da fenomenologia semiótica ("articulação teórica e prática do pensamento contemporâneo francês"), na qual "a experiência consciente ${ }^{13}$ é entendida em sua associação com os conceitos de intencionalidade, sentido e existência" (1997, p.305) e envolve, em termos gerais, uma circularidade entre a semelhança da percepção e expressão que o sujeito faz de si mesmo e a "alteridade da expressão e da percepção com o outro" (1997, p.309). Ressaltamos que nosso trabalho não tem a intenção de avançar no campo da psicologia; todavia, é de grande valor ressaltar a similaridade entre o que se propõe nela e na semiótica (que tem parte de suas origens na fenomenologia) e como as propostas de estudo do sujeito, sua identidade, representação e sentido se encontram.

Gestos e falas revelam a corporeidade de uma consciência situada enquanto constituição de uma mensagem. É sempre uma relação entre um remetente e um destinatário[...]; [...] é a relação entre um eu que fala e outro que ouve, entre um eu que se mostra em gestos e um outro que vê um movimento, ou mesmo entre um eu e os seus pensamentos (GOMES, 1997, p. 311).

O texto, quando compreendido como objeto de significação, adquire um status de organicidade, pois deixa de ser uma aglomeração de palavras e frases e passa a ser um objeto com procedimentos e mecanismos de construção - mesmo quando assim não o pareça. Se entendemos que um texto veicula sentido, entendemos que esse sentido é arquitetado e estruturado. Fiorin lembra muito bem que a palavra texto origina-se do latim texo, que significa tecer. "Da mesma forma que um tecido não é um amontoado desorganizado de fios, o texto não é um amontoado de frases, nem uma grande frase. Tem ele uma estrutura, que garante que o sentido seja apreendido em sua globalidade [...]" (FIORIN, 1995, p.165-166),

\footnotetext{
12 "A tradição da psicologia fenomenológica da Duquesne University tem o seu início com o estudo pioneiro de Van Kann (1959). O autor apresentou uma forma de análise fenomenológica para o estudo da experiência de sentir-se realmente entendido. Esta concepção aplicada de fenomenologia empírica foi reconhecida por Rogers (1970) como inovadora e importante para a pesquisa em psicologia humanista (Gomes, 1997, p. 306)

${ }_{13}$ "A experiência consciente esclarece-se a partir da significação dos acontecimentos que a constituem. Os objetos da consciência ganham sentido na contextualização de interligações que aparecem organizados em forma de estrutura. Esta estrutura, enquanto experiência consciente do mundo vivido, é uma matriz social e uma expressão dos construtos mentais (Schütz, 1962); um mundo no qual a vida cotidiana se desenrola e um lugar onde apresentam-se nossas metas e objetivos (Gurwitsch, 1957/1966); e contém os entrelaçamentos inextrincáveis do eu com o outro e com o mundo (Merleau-Ponty, 1945/1971) (Idem, 1997, p. 308).
} 
ou seja, uma estrutura interna que liga e torna cada uma de suas partes dependente do todo.

Preocupando-se com o texto em relação aos dispositivos usados na construção de uma totalidade de sentido, a Semiótica francesa coloca-se como uma teoria gerativa, ou seja, que gera modelos de análise de sentido que sejam capazes de apreender os vários níveis de processo de significação desse texto, que podem ser simples ou complexos, abstratos ou concretos. É também uma teoria sintagmática, pois estuda a produção e a interpretação desse discurso, não unidades lexicais; preocupa-se com o campo da expressão e do conteúdo. Finalmente, é uma teoria geral, já que qualquer tipo de texto é aceito - como já mencionado antes - e tem como postulado a unidade de sentido que se manifesta das mais variadas formas, ou seja, um conteúdo que pode ser expresso por diferentes planos de expressão (GOMES, 1997; FIORIN, 1995, p. 167).

Portanto, para que se possa construir o sentido de um texto, a Semiótica lança mão do que chama de percurso gerativo de sentido, que se divide em três partes: nível fundamental, nível narrativo e nível discursivo - cada um desses três níveis observa o aspecto sintático e semântico do texto. Como sintaxe entendemos - grupo de mecanismos responsáveis pela ordenação dos conteúdos; como semântica, os conteúdos que estão envolvidos nos arranjos sintáticos.

Observe-se, no entanto, que não se trata de uma sintaxe puramente formal, ou seja, não se opõem sintaxe e semântica como o que não é dotado de significado e o que tem significado. Um arranjo sintático é dotado de sentido. Por conseguinte, a distinção entre esses dois componentes reside no fato de que a semântica tem uma autonomia maior que a sintaxe, o que significa que se podem investir diferentes conteúdos semânticos na mesa estrutura sintática (FIORIN, 1995, p. 167). 


\subsection{SOBRE AS ANÁLISES}

O capítulo dois trata das análises das entrevistas. É extremamente importante ressaltar o caminho que decidimos tomar em relação aos termos comumente utilizados na Semiótica. Lara e Matte, em um tom até humorado, reconhecem que a metalinguagem da área assusta mais até do que as dificuldades peculiares a uma teoria. "Se não se tratar de um indivíduo persistente, ele acabará desistindo antes mesmo de começar" (2009, p.339). Nosso desejo é que esta pesquisa alcance interessados por Semiótica tanto quanto leitores que conhecem pouco da área, assim como disléxicos, que podem buscar por nosso texto unicamente por empatia ao tema. Para isso, nos baseamos nos princípios da semiótica francesa que permearão todo o trabalho; porém, com cuidado para que a metalinguagem não impedisse a compreensão do texto, aparecendo, por isso, em momentos pontuais.

Segundo ponto a ser esclarecido é que essa teoria que nos dispomos a utilizar como ferramenta de análise possui várias camadas, como já explicado na primeira parte deste capítulo. Dentre tantas possibilidades, selecionamos aquelas que nos pareceram mais eficazes e úteis para o tipo de compreensão de narrativa que buscamos.

$\mathrm{Na}$ análise das entrevistas, buscamos por uma linguagem simples e direta com o objetivo de organizar a narrativa, que fica cortada pelas perguntas e interrupções, em um texto que possibilitasse ao leitor enxergar o discurso e as reflexões dos sujeitos entrevistados.

A seguir, buscamos determinar as oposições semânticas, que se encontram no nível das estruturas fundamentais e a "partir das quais se constrói o sentido do texto" (BARROS, 2011, p.10). A oposição semântica resume-se na fórmula a versus $b$ (divino vs. mundano, por exemplo) e traduz o modo como o texto é articulado. Algo importante a ser lembrado para todas as etapas dessa análise é o fato de uma entrevista não ser um discurso corrido - o entrevistado não é livre para falar sobre um tema somente. Ao fazer perguntas, o entrevistador muda o rumo do discurso e quebra sequências na narrativa, o que pode acabar gerando mais de uma oposição semântica, algo que não aconteceria, por exemplo, em um poema que desenvolva um mesmo tema do início ao fim, e, como consequência, mantenha o foco em uma mesma oposição semântica. 
A última parte debruça-se sobre os temas e as figuras. "Os valores assumidos pelo sujeito da narrativa são, no nível do discurso, disseminados sob a forma de percursos temáticos e recebem investimentos figurativos" (BARROS, 2011, p.68). Textos podem ser mais temáticos ou mais figurativos. Barros dá como exemplo os discursos políticos e acadêmicos que, por não completarem um percurso figurativo completo, são considerados "discursos de figuração esporádica", por isso conhecidos como "discursos temáticos"; discursos figurativos, portanto, lançam mão de figurativização, cujo grau pode variar.

Tematizar um discurso é formular os valores de modo abstrato e organizá-los em percursos. Em outras palavras, os percursos são constituídos pela recorrência de traços semânticos ou semas, concebidos abstratamente. [...] Pelo procedimento da figurativização, figuras do conteúdo recobrem os percursos temáticos abstratos e atribuem-Ihes traços de revestimento sensorial (BARROS, 2011, p.68, 72) 


\subsection{JUNÇÃO}

O método de análise da semiótica francesa permite que vários níveis do discurso sejam descortinados e explorados, o que se torna possível através do estabelecimento de uma estratégia que se organiza em torno de um sujeito e um objeto investidos de um valor semântico - o desejo - "equivalendo o sujeito ao ser querente (ativo) e o objeto ao ser querido (passivo)" (SILVA, 2009, p. 48). Fundamentados nesse conceito de querente e querido mais o entendimento de que a existência semiótica de um sujeito acontece pela relação desse sujeito com um objeto, portanto, "um sujeito só tem existência na medida que está em relação com um objeto" (FIORIN, 2000, p.178) é que estabelecemos, dentro desse modelo da semiótica francesa, quais elementos seriam pertinentes para estabelecer como se dá a construção da imagem discursiva do disléxico.

Portanto, a ideia de um sujeito em conjunção ou disjunção com um objeto de valor está presente em todo nosso trabalho. Trata-se, em resumo, do que a semiótica chama de enunciado de estado (qualifica o estado no qual o sujeito encontra-se) e um enunciado do fazer (relativo à transformação, ao movimento do sujeito na busca pela transformação de um estado para outro). As transformações do sujeito se dão por meio da conjunção ou disjunção com um objeto de valor, ou seja, uma mudança (ou não) na relação entre sujeito e objeto. Fiorin explica que na frase "Pedro é rico", vemos uma relação de junção do sujeito Pedro com o objeto riqueza. Em "Pedro não é rico", temos uma quebra na relação do sujeito Pedro e o objeto riqueza, ou seja, um estado de disjunção (1995, p.168). Fica claro, portanto, que a relação sujeito-objeto não é consistente nem constante e sofre alterações ao longo da narrativa, o que pôde ser percebido nas entrevistas coletadas - embora o eixo da conversa seja a dislexia, verificamos que os sujeitos têm (e tiveram) diferentes momentos de relação com um mesmo objeto, causados por variadas razões e que tiverem efeitos marcantes nas trajetórias dos entrevistados. "O sujeito do fazer é um agente responsável pela mudança de seu estado ou de outro sujeito. O sujeito de estado é paciente e passivo e serve para representar um determinado estado do sujeito em relação ao seu objeto de desejo" (SILVA, 2009, p. 49).

O conceito de junção - gerando conjunção e disjunção - mostrou-se essencial para que pudéssemos estabelecer, entender e dar sentido à trajetória desse sujeito que, invariavelmente se sentindo diferente daqueles com quem convive, constrói e 
desconstrói relações baseado em como se sente ligado, conectado, a cada uma delas. "Os objetos são investidos de um valor. Por isso, o sujeito busca, em verdade, não o objeto, mas o valor nele investido" (SILVA, 2009, p.48). Um carro, um relógio de marca famosa ou um telefone da moda são desejados pelo valor que conferem ao sujeito - status, reconhecimento, conforto. Sabemos, no entanto, que valores mudam de indivíduo para indivíduo, de cultura para cultura. "No mundo moderno, a noção subjetiva de valor é retomada por Thomas Hobbes (1588-1679) ${ }^{14}$, que dizia que o valor não é absoluto, mas depende da necessidade de um juízo. Valor, portanto, é aquilo que é estimado como tal através de um juízo" (GOERGEN, 2005, p.987).

Determinamos, portanto, que o sujeito tem, basicamente, três objetos de valor:
a escola
ser disléxico
a língua inglesa

Segundo Goergen, Christian Ehrenfelds (1859-1932) ${ }^{15}$ "define valor como simples desejabilidade. [...] Valor não é a coisa desejada, mas o objeto desejável". Citando Wilhelm Dilthey (1833-1911) ${ }^{16}$, explica que os valores são determinados e instituídos pela história. "A objetividade deriva apenas da correlação entre sujeito e objeto. Não existem valores absolutos; só existem aqueles que os homens reconhecem em determinadas circunstâncias" e que, por isso, valores não são uma "realidade ontológica à parte", mas sim uma "qualificação categorial que pode referirse a qualquer objeto" (GOERGEN, 2005, p.988-989).

\footnotetext{
${ }^{14}$ Thomas Hobbes (1588-1679) foi teórico político, filósofo e matemático inglês. Sua obra mais evidente é "Leviatã", cuja ideia central era a defesa do absolutismo e a elaboração da tese do contrato social. Hobbes viveu na mesma época que outro teórico político, John Locke, que era defensor dos princípios do liberalismo, ao passo que Hobbes pregava um governo centralizador (http://www.e-biografias.net/thomashobbes)

${ }^{15}$ Psicólogo e filósofo de origem austríaca, Ehrenfels destacou-se na história da Psicologia por ter sido um dos pioneiros da teoria da Gestalt. O autor utiliza o termo Gestalt para se referir a um complexo conjunto de dados que necessitavam de mais do que a experiência sensorial e imediata para serem percebidos. Dito de outro modo, Ehrenfels defendia que para haver apreensão de um objeto seria necessário que todos os seus componentes fossem percebidos como um todo (http://www.infopedia.pt/Sehrenfels)

${ }^{16}$ Wilhelm Dilthey (1833-1911) foi um filósofo historicista alemão que deixou importante contribuição para a metodologia das Ciências Humanas. É considerado o criador do historicismo. Contestou a ampla influência que as doutrinas positivistas possuíam sobre as ciências humanas, especialmente as sociais, as históricas $e$ as do psiquismo (http://www.ebiografias.net/wilhelm_dilthey/)
} 
Gostaríamos de relembrar que, mesmo não usando seguidamente os termos conjunção e disjunção, o conceito que representam faz parte de todas as análises deste trabalho.

Recorremos também à dinâmica das modalidades e modalizações na produção de paixões na narrativa do disléxico.

As paixões, do ponto de vista da semiótica, entendem-se como efeitos de sentido de qualificações modais que modificam o sujeito de estado. Essas qualificações organizam-se sob a forma de arranjos sintagmáticos de modalidades ou configurações passionais. [...] Numa narrativa, o sujeito segue um percurso, ou seja, ocupa diferentes posições passionais, saltando de estados de tensão e de disforia para estados de relaxamento e de euforia e vice-versa (BARROS, 2011, p.47).

Nosso objetivo é levantar quais paixões (amargura, desilusão, frustração, raiva, medo, vergonha) originam-se das modalizações das modalidades potencializantes (crer), virtualizantes (querer/dever), atualizantes (saber/poder) e realizantes (fazer/ser).

As paixões aparecem no discurso como portadoras de efeitos de sentido muito particulares: ele exala como um cheiro confuso, difícil de determinar. A interpretação que a semiótica reteve é que esse perfume específico emana da organização discursiva das estruturas modais. Passando de uma metáfora à outra, poder-se-ia dizer que esse efeito de sentido provém de certo arranjo molecular: não sendo propriedade de nenhuma molécula em particular, ele resulta de sua disposição do todo. Uma primeira constatação impõe-se: a sensibilização passional do discurso e sua modalização narrativa são co-ocorrentes, não se compreendem uma sem a outra, e, no entanto, são autônomas, submissas provavelmente, ao menos em parte, a lógicas diferentes (GREIMAS; FONTANILLE, 1993, p.21).

Feito isso, examinamos e discutimos os estereótipos relacionados aos disléxicos e o impacto que causam na vida desses indivíduos. Tratamos também do peso dos estigmas e preconceitos e do papel da escola e professor na busca por uma compreensão de tais questões de forma que venham a ter um impacto positivo e eficaz na realidade de portadores de dislexia.

Finalmente, apoiamo-nos no estudo sobre o reconhecimento de Paul Ricoeur (2006) a fim de traçarmos como acontece o reconhecimento de si do disléxico. Organizada pelo conceito do homem capaz, a proposta de Ricoeur olha para um sujeito que se desdobra no indivíduo que pode dizer, fazer, narrar e narrar-se e assumir-se imputável por seus atos. 


\section{ANÁLISES DAS ENTREVISTAS}

\subsection{IVANA, 57 ANOS, FONOAUDIÓLOGA}

Ivana percebia ser diferente dos outros alunos e tal percepção nasceu das dificuldades enfrentadas na escola - lentidão na escrita e ortografia - que se estenderam à vida adulta. Sua fala é permeada pela ideia de perseverança e quebra de obstáculos e estereótipos. Colocando-se como uma disléxica que gosta de livros, imagem que vai de encontro àquela comumente encontrada quando o assunto é dislexia, deixa claro que foi sua determinação que a fez vencer muitos dos obstáculos impostos por sua condição. Afirma que "demorava uma vida" para ler seus livros, pois comparava seu ritmo a de seus colegas, mas chegava ao fim de suas leituras.

A despeito de todos os contratempos e da clara complexidade no cumprimento de tarefas que os outros pareciam exercer sem grandes dificuldades, Ivana é capaz de olhar para si e enxergar suas qualidades, deixando de lado a modéstia e sem receio de parecer presunçosa. No entanto, sofria, porque mesmo sabendo ser capaz, não obtinha os resultados almejados. A sensação de burrice e estupidez acompanhava a certeza de que era inteligente, um "contraste difícil". O saber ser capaz perde força frente às dificuldades oriundas da dislexia.

"Burra mesmo, você tem aquela coisa... Você não aprende, não consegue. E, por outro lado, fala: 'poxa, mas eu sou tão inteligente em outras coisas."'

Em vista disso, Ivana sente-se enfraquecida e sua autoestima nem sempre dá conta de manter-se inabalada. Como se tivesse um segredo, vivencia situações nas quais teme ser descoberta e torna-se um sujeito que, ao ser elogiado, busca aliviar o peso que esse elogio traz para si:

"Ah, nossa, como você é inteligente, como você é rápida."

"Eu falava assim: 'Daqui a pouquinho você vai ver que eu não sou tão inteligente assim."'

Esse movimento de chamar a atenção para sua fraqueza origina-se do conflito na estrutura modal "ser" versus "parecer". É um esforço de esclarecer fatos para não decepcionar o outro - pareço inteligente, mas não sou - que, porém, acaba 
estabelecendo uma inverdade, pois ela sabe que é inteligente e capaz, mas se sente oprimida pelo peso de suas aptidões. Prefere, então, mostrar-se como alguém menos capaz para não correr o risco de frustrar-se mais uma vez. Todavia, esse ciclo conflituoso resulta em algo positivo, pois Ivana sai dele capaz de perceber que as pessoas são diferentes e que possuem talentos distintos, percepção essencial para que ela consiga aceitar-se como disléxica.

A relação com a língua inglesa também é conflitante. Apesar de afirmar que línguas não eram problema, Ivana diz que o idioma inglês não progrediu, oposto ao que aconteceu com outros idiomas. Ela entende que a possibilidade de convivência com outras línguas facilitou o aprendizado, justificativa ouvida também de outros entrevistados.

Muito cedo Ivana toma as rédeas de uma vida permeada pelas dificuldades impostas pela dislexia. Afirma que desenvolveu estratégias, que foram essenciais para que conseguisse compreender muitas coisas - e ganhou competência para a vida.

Ivana retoma o conflito na vida escolar

"Existia o aluno inteligente e o aluno burro; eu estava no segundo grupo, não é? E aí, eu estava lutando contra isso, para entrar no primeiro grupo, não é?"

Sabe ser inteligente, mas se vê colocada entre os burros. Apesar de sua luta para sair do grupo ao qual sabe não merecer pertencer, ela acaba frustrada, pois, a despeito de seus esforços, a vitória por conseguir passar de ano é ofuscada pelo fato de ser uma aluna que não é notada e que nunca consegue atingir um dez, mesmo quando a nota máxima é a expectativa até do professor. Retoma-se aqui a situação na qual alguém espera muito dela, mas à qual ela não consegue corresponder. Notam-se, no entanto, dois modos de ela lidar com a situação, mas que acabam por ter o mesmo desfecho: parecer ser o que não é. Na primeira ocorrência, Ivana apressa-se para baixar as expectativas em relação a sua capacidade; aqui, esforça-se para corresponder às expectativas, mas falha.

"Então, apesar dela (a professora) achar que eu era aluna nota 10, eu nunca tive um 10 em ciências. Então isso era altamente frustrante." 
Interessante ressaltar que Ivana tomou a decisão de buscar por um diagnóstico formal bem tarde, mostrando como foi difícil encarar a dislexia, mesmo tendo pleno conhecimento de sua condição. Não querer saber a privou de uma conciliação interna, pois ela mesma afirma que sofreu por fugir da questão. $\mathrm{Na}$ faculdade, esquivava-se dos pacientes de leitura e escrita até o dia em que reconheceu que ser disléxica a ajudaria a entendê-los, extraindo dali uma experiência positiva.

Ao tratar de sua experiência com a língua inglesa, Ivana retoma sua facilidade com o idioma ao mesmo tempo em que relata uma queda gradativa em seu rendimento, criando uma situação de conflito. O declínio é atribuído ao professor e escola ruins assim como a atividades desestimulantes; indisciplina, ausência de aulas e brigas com professores também são fatores que contribuíram para seu rendimento baixo.

Reaparece a oposição entre os idiomas latinos ("o espanhol é maravilhoso") e a língua inglesa ("eu não memorizo uma música"). A frustração é um sentimento recorrente que nesse momento vem à tona pelo fato de Ivana não conseguir cantar em inglês, pois aprender a cantar foi o que a motivou a estudar a língua.

"É frustrante, é frustrante. Você se sente igual àquela menina lá do...como é que chama...aquele programa horroroso... Aquele programa de televisão, Big Brother, que a menina cantava." 17

O medo de ter seu segredo descoberto reaparece na terceira ocorrência de uma situação na qual Ivana precisa lidar com a expectativa de terceiros. Entrevistar pacientes e/ou pais é um momento de tensão devido às suas dificuldades de ortografia. Pela primeira vez temos uma narrativa de êxito, na qual não recorreu à autodepreciação nem acabou frustrada. Consegue vencer o pânico do momento porque desenvolveu uma estratégia para enfrentar a situação:

17 A participante do Big Brother se chama Solange Cristina (ou Sol) e ficou famosa por cantar a música "We are the world" de maneira peculiar, já que pronunciava as palavras a seu próprio modo. Virou, por isso, motivo de piada nacional. 
"Dá aquele nervoso porque o pai está na sua frente, entendeu? Um desespero, me dá um branco na hora. E assim, o que eu faço? Faço um formulariozinho onde eu já escrevo como que é certo."

Em um retorno à frustração gerada pela dificuldade com a língua inglesa, Ivana expressa a facilidade com o espanhol, trazendo de volta o fato de que lida mais tranquilamente com idiomas latinos. Para ela, aprenderia se pudesse vivenciar o idioma inglês, pois acredita que a escola não dá conta desse papel.

Sobre ser disléxica, Ivana relata a experiência como sofrida, mas afirma que a "dislexia é um dom"; assevera que é "uma experiência dolorosa, estranha. É uma experiência bonita". O percurso de sua história tem aqui um momento de maturidade, de aceitação e de compreensão de que pessoas são feitas de lados positivos e negativos, seja qual for a história de cada um.

Ivana tem um percurso narrativo permeado pela perseverança. A rigidez, que acredita ter herdado do pai (para ela, também disléxico), foi a força que a fez vencer a falta de atenção, característica comum a disléxicos. Simplesmente não aceitava ser assim - e superou-se.

"Mas eu era uma pessoa tão rígida que, quando eu tinha que me concentrar, eu me concentrava tanto. Então não entendia esse negócio de ser desatenta."

Ao fechar sua narrativa, Ivana volta a afirmar que a dislexia é um dom e deixa evidente que vive em harmonia com ela, mesmo a experiência sendo dolorosa e estranha. Relata as dificuldades mais comuns em seu dia a dia, tais como desorientação espacial e temporal, perdas de compromissos por causa das constantes confusões de datas e o medo de ter prejuízo ou causar prejuízos a terceiros. Conclui que a frustração com o idioma inglês se tornou um problema pequeno quando comparado a elas. 


\begin{tabular}{|l|}
\hline Oposições semânticas \\
\hline "Burrice" x Inteligência \\
\hline
\end{tabular}

\begin{tabular}{|l|}
\hline Figuras \\
\hline "...eu demorava uma vida para ler esses livros." \\
"Quando você vai na escola, normalmente eles socam muito a oralidade e não dão \\
as regras."
\end{tabular}

\begin{tabular}{|c|c|}
\hline Temas & \\
\hline Dificuldades & $\begin{array}{l}\text { Lentidão, ortografia, leitura, } \\
\text { desorientação espacial e temporal, língua } \\
\text { inglesa, esporte; falta de disciplina, brigas } \\
\text { com professores, baixa autoestima, memória } \\
\text { ruim. } \\
\text { "Repeti nas matérias mais } \\
\text { estúpidas." } \\
\text { "Preciso da escrita." } \\
\text { "Eu preciso muito das regras." } \\
\text { Confundir horários de pacientes, } \\
\text { esquecer compromissos. Prejuízos } \\
\text { financeiros. }\end{array}$ \\
\hline Facilidades & $\begin{array}{l}\text { "Ping-pong eu jogo muito bem, } \\
\text { xadrez, tudo que é raciocínio, tudo que é } \\
\text { carta, baralho". } \\
\text { Italiano e espanhol. }\end{array}$ \\
\hline Forca de vontade & $\begin{array}{l}\text { "Só que eu lia por determinação." } \\
\text { "Aprendi a ler e a escrever sozinha." } \\
\text { "...hoje eu consigo compreender } \\
\text { melhor porque é que eu fui buscar esse tipo } \\
\text { de estratégia." } \\
\text { "...porque, se me deixasse, por } \\
\text { exemplo, em geografia, chegava na época } \\
\text { das férias eu estudava e tirava nota." } \\
\text { Formulário no atendimento a }\end{array}$ \\
\hline
\end{tabular}




\begin{tabular}{|c|c|}
\hline & $\begin{array}{l}\text { pacientes como estratégia. } \\
\text { "Mas eu era uma pessoa tão rígida } \\
\text { que, quando eu tinha que me concentrar, eu } \\
\text { me concentrava tanto. Então não entendia } \\
\text { essa história de desatenta." }\end{array}$ \\
\hline $\begin{array}{c}\text { Conflito } \\
\text { desejos/frustracões }\end{array}$ & $\begin{array}{l}\text { "Tenho em algumas coisas muita } \\
\text { facilidade." } \\
\text { "Então, por um lado você se sente } \\
\text { assim estúpida, entendeu?" } \\
\text { "Mas eu sabia que podia ter notas } \\
\text { melhores." } \\
\text { "Então, apesar de eu achar que era } \\
\text { aluna nota 10, eu nunca tive um } 10 \text { em } \\
\text { ciências." } \\
\text { "Não memorizo música em inglês." } \\
\text { "Porque, se você consegue um nível } \\
\text { concentração até com todos os } \\
\text { desfavorecimentos possíveis, por que não } \\
\text { funciona, entendeu?" } \\
\text { "Adoraria estudar. A minha frustração } \\
\text { é não falar inglês". } \\
\text { "Eu gostaria de cantar em inglês." }\end{array}$ \\
\hline Segredo & $\begin{array}{l}\text { "Nossa, como você é inteligente." } \\
\text { "Espere para ver um pouquinho." }\end{array}$ \\
\hline Lição de vida & $\begin{array}{l}\text { Lidar com os extremos. } \\
\text { Trabalhar, na faculdade, com } \\
\text { pacientes de leitura e escrita. } \\
\text { "É uma experiência sofrida." - } \\
\text { referindo-se a ser disléxica. } \\
\text { "Hoje...eu acho que a dislexia é um } \\
\text { dom." } \\
\text { "É uma experiência dolorosa, } \\
\text { estranha. É experiência bonita. Com a } \\
\text { maturidade, a espiritualidade, tudo isso }\end{array}$ \\
\hline
\end{tabular}




\begin{tabular}{|c|c|}
\hline & $\begin{array}{l}\text { ajuda você a driblar tudo isso e entender um } \\
\text { outro valor das coisas." } \\
\text { Aprendeu a lidar com as diferenças } \\
\text { nas pessoas. } \\
\text { Venceu a baixa autoestima. } \\
\text { "Você não precisa ser boa jogadora } \\
\text { para ser aceita." } \\
\text { Chegou à conclusão de que o inglês } \\
\text { é detalhe perante outras dificuldades na } \\
\text { vida. } \\
\text { "Num certo momento isso passa a } \\
\text { ser engraçado, divertido. Depois você acaba } \\
\text { brincando com a situação, mas tem coisas } \\
\text { que comprometem." }\end{array}$ \\
\hline Fuga & $\begin{array}{l}\text { Evitava o laudo e, na faculdade, } \\
\text { evitava lidar com pacientes de leitura e } \\
\text { escrita. }\end{array}$ \\
\hline Língua inglesa - altos e baixos & $\begin{array}{l}\text { Era boa aluna, professor ruim, aulas } \\
\text { sem estímulos. }\end{array}$ \\
\hline Família & $\begin{array}{l}\text { "Meu pai era disléxico, na minha } \\
\text { opinião." }\end{array}$ \\
\hline
\end{tabular}




\subsection{MARCELO, 20 ANOS, ESTUDANTE DE ENGENHARIA AMBIENTAL}

"Me falta alguma coisa". Essa frase pode resumir a fala de Marcelo ao traçar sua narrativa. Uma falta que ele não consegue nomear - é difícil dizer o que é. Sabe, porém, o que não é: falta de inteligência. Tal ausência faz com que se considere uma pessoa fora do padrão, alguém não comum; é um aluno que se sente perdido e impotente diante da complexidade que é, para ele, tentar entender o professor, algo que não consegue, por mais que tente.

"...uma falta de alguma coisa, de algum mecanismo, de alguma ligação que faz com que a pessoa possa entender igual a uma pessoa comum consegue entender uma matéria..."

A luta com a língua inglesa teve início quando era pequeno e, apesar de a mãe ser professora - um ambiente ainda mais propício para um aprendizado mais tranquilo - a experiência foi traumática. A frustração, oriunda da falta de sucesso mesmo com a ajuda recebida em casa, intensificou-se quando, aos 16 anos, foi colocado em uma turma com alunos de 12, o que também não resolveu seu problema. O idioma foi sendo deixado de lado à medida que outras atividades foram tomando conta de sua rotina.

"(sobre estudar com alunos mais jovens) Então, isso realmente foi uma frustração, que eu falei: 'pô, eu não consigo avançar."'

A presença materna é clara na vida escolar de Marcelo e a ajuda da mãe era o que possibilitava um rendimento pelo menos razoável; porém, quando a mãe decide que ele precisa aprender a caminhar sozinho, esse rendimento cai. Somente o tratamento e, com ele, a medicação e o que Marcelo chama de "outros mecanismos" de estudo trouxeram uma mudança marcante para seu aprendizado: da "água para o vinho" é como ele descreve a transformação.

"Porque antes, pô, quase impossível, muito difícil. Hoje em dia não vou dizer que é fácil, mas bem mais fácil de alcançar." 
Conversação é a habilidade na qual Marcelo diz ter mais problemas, pois não conseguia registrar vocabulário, por mais que estudasse. Assim como quando tentava entender o professor, insistindo e prestando atenção, fazia o mesmo com as palavras, sem sucesso em ambas as situações. Ele retoma aqui a ideia da falta, esse algo que não possuiria e que o impediria de aprender.

Sendo uma pessoa com grande interesse por aprender e entender como as coisas funcionam (hoje ele estuda engenharia), Marcelo define-se como uma criança triste na escola, pois seu anseio por aquisição do saber nunca foi totalmente satisfeito; muito pelo contrário, foram tentativas e mais tentativas frustradas de aprendizado, pois, segundo ele, "sempre tinha essa lacuna para ser completada". Uma criança triste e vazia, mas vazia de conhecimento.

No ambiente escolar, era o garoto cujos professores sempre acreditavam ter um problema. A leitura irregular (típica da dislexia) aventava para um problema de visão e o constante não entender levantava a hipótese de problema de audição - "eu e minha mãe fomos, nossa, milhões e milhões de vezes para fazer exames de visão, de audição"..."eu nunca tive nada, nada". A pista de que o problema pudesse ser outro veio de uma psicopedagoga e Marcelo recebe, aos 14 anos, o diagnóstico correto: déficit de atenção e dislexia. Os supostos problemas de visão e audição afetaram o rendimento de Marcelo que, assim como Ivana, nunca conseguiu tirar uma nota máxima:

"Eu sempre fui uma criança mediana, sabe? Sempre 6,7; nunca tirei um 8,9 e nem 4,3."

Mais uma vez, Marcelo retoma a sensação de falta, mas agora como algo vindo de seus professores:

faltando."

\section{"...mas os meus professores, eles sentiam que tinha alguma coisa}

\section{faltando.}

Em nenhum momento de sua narrativa Marcelo mostra ressentimento em relação à escola, professores ou colegas; pelo contrário, parecia sentir-se acolhido. Menciona que os professores buscavam ajudá-lo tentando diferentes formas de explicar a matéria ou dando atenção extra, porém, diz: "...eles (os professores) 
nunca passaram a mão na cabeça...me trataram como diferente, sabe?". A mãe, novamente, parece ter tido um papel muito importante em sua vida escolar:

"(sobre seu problema) Sim, eu sempre costumava avisar todos os professores. Minha mãe também sempre fez questão de, quando começava 0 ano, no colégio ou até no cursinho, falar com os orientadores do colégio"... "que também não era para me tratar como um queridinho, sabe?"

Marcelo mostra uma postura de aceitação de sua condição de disléxico ao aceitar o tratamento diferenciado no ENEM (Exame Nacional de Ensino Médio) - ali entendeu ser, além de um direito, uma necessidade. Pôde fazer a prova em uma sala separada, uma vez que precisava de mais tempo que alunos sem nenhum distúrbio de aprendizagem, e não se incomodou com isso.

O fechamento da narrativa de Marcelo mostra uma pessoa conciliada com a dislexia e com a língua inglesa - maturidade e medicação ajudaram no processo. Por conviver com estrangeiros, ele é forçado a usar o idioma, o que considera, apesar de soar contraditório, um "aprender livremente", pois compara o aprendizado hoje, tranquilo, com o da escola, difícil e infrutífero. 


\begin{tabular}{|l|}
\hline Oposições semânticas \\
\hline Presença $\times$ Falta \\
\hline
\end{tabular}

\begin{tabular}{|l|}
\hline Figuras \\
\hline "Sempre foi uma pedra no meu sapato, o inglês." \\
\hline "...e isso, para o meu aprendizado, foi mudando da água para o vinho." \\
\hline
\end{tabular}

\begin{tabular}{|c|c|}
\hline Temas & \\
\hline Dislexia & $\begin{array}{l}\text { "...falta de alguma coisa". } \\
\text { Criança triste e vazia. } \\
\text { Tratamento diferenciado não } \\
\text { aceito na escola, mas aceito no ENEM. }\end{array}$ \\
\hline Língua inglesa & Trauma, frustração, luta \\
\hline Família & Presença e ajuda da mãe. \\
\hline Dificuldades & $\begin{array}{l}\text { Problemas para entender os } \\
\text { professores. } \\
\text { Déficit de atenção. } \\
\text { Estudava, mas não via resultados. } \\
\text { Conversação, retenção de } \\
\text { vocabulário. }\end{array}$ \\
\hline Facilidades & $\begin{array}{l}\text { Aprender inglês hoje, fora da } \\
\text { escola. }\end{array}$ \\
\hline Progresso & $\begin{array}{lll}\text { Tratamento, } & \text { medicação } & \mathrm{e} \\
\text { estratégias. } & & \\
\end{array}$ \\
\hline Escola & $\begin{array}{l}\text { Suspeita de problema } \\
\text { (audição/visão) } \\
\text { Aluno mediano. } \\
\text { Compreensão dos professores. }\end{array}$ \\
\hline
\end{tabular}


2.3. TIAGO, 26 ANOS, FUNCIONÁRIO DE UMA BIBLIOTECA, PRETENDE ESTUDAR INFORMÁTICA

Tiago foi diagnosticado com dislexia, $D A^{18}$ e agressividade quando pequeno, mas não é capaz de apontar exatamente quando. A troca de letras foi o sintoma que chamou a atenção para o problema; a troca ainda acontece, porém, por ter consciência dela, ele consegue intervir e corrigir.

O interesse em estudar a língua inglesa fora da escola só veio aos 21 anos, quando Tiago começou a trabalhar. Decidiu fazer um teste para ver se conseguiria aprender. Matriculou-se em uma escola de idiomas, mas diz que não conseguiu acompanhar. Tiago, na verdade, sentiu-se culpado pelo seu fracasso, o que 0 impeliu a ir à escola e pedir desculpas por não ter sido capaz de seguir o curso. Segundo ele, informação demais que não foi capaz de assimilar. Quando avançou um pouco e precisou produzir mais em sala, desistiu, pois não conseguiu acompanhar a turma, que resultou em resultado ruim na prova.

"Aí eu pedi desculpa lá na escola; infelizmente não deu por conta das dificuldades de ensino que eu tenho."

A aula particular aparece, então, como opção para um aluno que precisa seguir seu próprio ritmo. Tiago claramente se mostra confortável com esse tipo de aula e sabe exatamente o que o ajuda em seu aprendizado: a dinâmica de uma aula que obedece a seu ritmo e o uso de fotos e figuras quando precisa memorizar algo. $\mathrm{Na}$ escola, memorização de vocabulário era um dos problemas. Hoje, parece satisfeito por estar "no segundo nível" e por conseguir entender algumas coisas sem tradução - coisas "bobinhas", mas que eram um grande problema no passado.

Tiago diz não ter tantos problemas de escrita; sente mais dificuldade em falar e entender, que parece se originar do problema de memória; no entanto, a liberdade em falar com a professora para tirar suas dúvidas o ajuda a progredir.

Retomando a época da escola de idiomas, diz que o momento que sentiu a necessidade de parar o curso foi quando não conseguiu transpor para a prova aquilo que havia estudado no curso:

${ }^{18}$ Distúrbio de Déficit de Atenção 
"Um período muito curto para absorver muita coisa. Realmente não consegui aplicar isso na prova."

Tiago nunca chegou a informar a coordenação da escola que tinha dislexia. A vontade de vencer e provar que era capaz de realizar uma atividade considerada normal acabou por causar certa frustração, já que não conseguiu avançar no curso.

"...eu não cheguei a informar, a falar que eu tinha certa deficiência. Porque eu queria provar para mim mesmo se eu era capaz de alguma coisa, não é? Se eu ia conseguir ou não fazer alguma coisa, digamos, normal. Mas aí acabei me atrapalhando com isso."

Foi através de redes sociais e pesquisas na internet que Tiago descobriu ser disléxico, o que o deixou chateado, "meio pra baixo". Mas esse sentimento vinha da reação das pessoas quando ele cometia erros de escrita - risadas, normalmente. Com uma atitude paciente, ele, depois da descoberta, começou a explicar a razão desses erros, quando, então, os amigos pediam desculpas. Mostrando ser muito consciente das limitações impostas à sua escrita pela dislexia, Tiago insiste em tentar escrever, pois entende que é praticando que irá melhorar.

Sobre ser disléxico, ele diz:

"Eu diria que é uma vida normal, você só vai ter um pouco de dificuldade, mas você vai superar as dificuldades, vai conseguir superar tudo."

Continua mencionando que haverá "atraso no ensino", mas que, com apoio família, médico - é possível superar cada uma das dificuldades, mas aponta que pode ser difícil para a família. No caso dele, foi um choque, já que sua irmã era "normal", mas que a descoberta ainda cedo possibilitou que ele tivesse progressos.

Tiago termina com um resumo tocante de como se sentia antes, na escola de idiomas, e hoje, tendo a atenção de um professor particular:

"...acho que eu era só mais um aluno qualquer (...) que não fazia diferença nenhuma (...)" 
"E agora eu acho que eu me sinto um pouco, no meu ver, eu me sinto um pouco mais importante." 


\begin{tabular}{|l|}
\hline Oposições semânticas \\
\hline Visibilidade $\mathrm{x}$ Invisibilidade \\
\hline Importância $\mathrm{x}$ Insignificância \\
\hline
\end{tabular}

\section{Figuras}

"É, estou comendo letra."

\begin{tabular}{|c|c|}
\hline Temas & \\
\hline Dislexia e comorbidades & DDA e agressividade. \\
\hline Dificuldades & $\begin{array}{l}\text { Inglês na escola de } \\
\text { entender, falar, escrever; } \begin{array}{l}\text { idiomas, } \\
\text { provas, }\end{array} \\
\text { memória; riso (dos outros). }\end{array}$ \\
\hline Facilidades & Inglês com professora particular \\
\hline Língua inglesa & Fracasso (na escola) \\
\hline Dislexia/ser disléxico & $\begin{array}{l}\text { Vida normal; dificuldades que } \\
\text { podem ser superadas. }\end{array}$ \\
\hline
\end{tabular}




\subsection{RENATA, 54 ANOS, PSICÓLOGA}

Renata levou o filho para avaliação de dislexia e, durante a consulta, identificou-se com as questões levantadas, descobrindo-se disléxica aos 37 anos. A dislexia, porém, já havia causado alguns danos: acreditando que nunca conseguiria fazer faculdade, ela abandonara a escola um ano antes de acabar o colegial e só retomou os estudos muito mais tarde, com um curso supletivo a distância. As dificuldades logo apareceram durante o curso e Renata lembra que não conseguia progredir em Matemática, Química, Física e Inglês sem ajuda.

O aprendizado da língua inglesa é marcado por duas tentativas, fora da escola, que não avançam de modo significativo. A primeira, motivada por uma viagem aos Estados Unidos, deixa Renata satisfeita por conseguir aprender vocabulário referente ao café da manhã - em algumas aulas junto com os filhos. $\mathrm{Na}$ época do curso supletivo, procurou também por uma professora e teve "algumas poucas aulas" - cinco ou seis. Resume assim esses dois momentos:

\section{"Então, é essa a minha experiência com professor de inglês."}

Da escola, tem lembranças ruins das aulas de inglês.

"Mal", "muito mal", "antes de saber da dislexia eu achava que tinha algum problema neurológico."

As palavras que Renata escolhe para se referir ao aprendizado idioma nunca são positivas. Sentia agonia, impotência e a menção à aula dava pânico. Da professora não tem nem mesmo lembrança do rosto, contrário da professora de francês, de quem "até lembrava o rostinho", deixando aqui claro que se sentia muito mais confortável com a língua francesa do que com a inglesa, relato já visto anteriormente neste trabalho.

\section{"...eu não me lembro nem quem me dava aula inglês"... "apagou."}

A metodologia com a professora particular foi ineficaz - listas de palavras para serem decoradas e chamada oral. Novamente Renata diz que se sentia mal e 
reforça que também não dava muita atenção às aulas por ter outras coisas para estudar. No entanto, tem um conflito por saber da necessidade de passar para conseguir tirar o diploma e é a necessidade de terminar o colegial que a move a ter aulas de inglês.

"Nossa Senhora, onde eu fui me meter?"; "E aí, assim, eu não me sentia confortável, não."

A luta que Renata tem com a língua inglesa é evidente, pois ela se coloca como uma pessoa "cara de pau", que enfrenta os problemas, mas que tinha uma "sensação de desconforto" muito grande com o idioma. Todavia, de modo até surpreendente, quando questionada sobre o que pensa em relação ao idioma hoje, diz:

"Eu acho que é parte de mim, eu acho que é apaixonante, porque eu amo música em inglês."

A música é um elo positivo entre Renata e a língua inglesa, a única coisa que chega a provocar alguma motivação para que volte a estudar. Ela tem vontade de aprender inglês toda vez que liga o rádio e ouve uma música no idioma, mas vislumbrar suas dificuldades a faz desistir do projeto.

"...tenho essa vontade, mas ela passa rapidinho. Passa muito rápido porque sei o quanto é difícil para mim."

Renata chama de "preguiça inominável" o que sente toda vez que pensa em retomar o aprendizado da língua inglesa e vive esse jogo entre o desejo, vontade e a falta de estímulo perante os obstáculos já conhecidos em relação a seu aprendizado. A vida, a rotina e os acontecimentos normais de sua vida a atropelam e a fazem deixar para trás qualquer movimento em direção à retomada de seus estudos de inglês.

Sobre ser disléxica, Renata tem uma posição muito equilibrada. Considera-se uma pessoa normal, com habilidades e "desabilidades", sendo a dislexia uma "desabilidade". Foram 14 anos de terapia que a ajudaram a conseguir esse 
equilíbrio. É consciente de que possui qualidades que faltam a não disléxicos e que entender isso diminuiu muito seu sentimento de frustração. Relata algo interessante: há dias nos quais sente a dislexia mais presente e tem, por exemplo, mais insegurança ao escrever. Sente-se confortável, no entanto, em tirar dúvidas com alguém que sabe de sua condição, que, primeiramente, ela chama de problema, para imediatamente corrigir:

"Aí a pessoa sabe do meu problema. Problema, não. Dislexia. " 


\begin{tabular}{|l|}
\hline Oposições semânticas \\
\hline Conforto $x$ Tortura \\
\hline
\end{tabular}

\begin{tabular}{|c|c|}
\hline Temas & \\
\hline Dificuldades & $\begin{array}{l}\text { "Eu achei que eu não ia conseguir } \\
\text { fazer nenhuma faculdade mesmo. E aí, } \\
\text { abandonei a escola". } \\
\quad \text { Matemática, Física, Química e } \\
\text { Inglês. }\end{array}$ \\
\hline $\begin{array}{llll}\text { Sentimentos } & \text { em } & \text { relacão } & \text { à } \\
\text { língua inglesa } & & & \end{array}$ & $\begin{array}{l}\text { Sentia-se mal, desconfortável; } \\
\text { fazia ela crer que tinha algum problema } \\
\text { neurológico; agonia, pânico, impotência, } \\
\text { fracasso, preguiça; leitura. }\end{array}$ \\
\hline $\begin{array}{l}\text { Sentimentos em relacão aos } \\
\text { professores }\end{array}$ & $\begin{array}{l}\text { Lembra-se do rosto da professora } \\
\text { de francês, mas não tem memória } \\
\text { alguma do professor de inglês. }\end{array}$ \\
\hline $\begin{array}{llll}\text { Sentimentos } & \text { em } & \text { relação } & \text { à } \\
\text { música } & & & \end{array}$ & $\begin{array}{l}\text { Faz o inglês ser apaixonante; é o } \\
\text { que motiva a aprender. }\end{array}$ \\
\hline Dislexia & $\begin{array}{c}\text { Normalidade, } \\
\text { habilidades, insegurança. }\end{array}$ \\
\hline
\end{tabular}




\subsection{RUBENS, 44 ANOS, GERENTE DE SISTEMAS}

Rubens descobriu sua dislexia há 16 anos. Depois de ler uma matéria sobre agitação em crianças decidiu levar a filha para um diagnóstico. Tornou-se o foco da entrevista depois de responder "sim" a todas as perguntas do questionário de avaliação - tinha então 28 anos e sua dislexia foi considerada moderada.

A vida escolar, portanto, aconteceu sem que ele soubesse o que afetava sua escrita e leitura. Era claro, contudo, que havia algo de errado e logo no primeiro ano já era um aluno questionador que colocava em dúvida a eficácia da escola.

"Primeiro, eu não sabia o que estava fazendo na escola; ninguém me dizia o quê que era para fazer lá, entendeu? E era um negócio confuso, que, algumas vezes, eu entendia."

Rubens sempre sentiu o peso da dislexia em sua vida escolar, mas foi na fase de alfabetização que a situação se tornou mais difícil. Era um aluno inquieto, que não prestava atenção e interrompia muito as aulas, causando até a saída de uma colega de sala.

"Porque ela não me aguentava mais assim...eu perguntava tudo para ela porque eu não estava entendendo, né..."

Rubens mostra ter consciência de suas capacidades mesmo não conseguindo ser bem-sucedido no ambiente escolar. Fala dos traumas sem vitimização ao dizer que os superava à medida que apareciam. Tinha muito claro que a escola busca resultados e que o aluno é medido pelo o que produz. Afirma que hoje tem a consciência de "saber ser capaz", ausente quando aluno, o que o fazia se sentir prejudicado.

"Eu não acredito que esse cara, aquela pessoa ou aquele menino pode ser considerado melhor que eu, sendo que eu sou muito melhor que ele."

O sentimento é de frustração. Os problemas de escrita e de leitura afetam a interpretação de texto que, por sua vez, impedem, por exemplo, a resolução de um 
problema de matemática - saber fazer uma conta não vale nada dentro desse contexto de dificuldades. Da mesma forma, é possível ser bom em ciências, mas nunca conseguir uma nota boa por causa dos erros de ortografia - "um 10 vira 5". Rubens afirma que nesse momento questiona a si mesmo - retomando aqui a comparação com alguém que, mesmo inferior a ele, obtém melhores resultados. Chama de "massacre" a avalanche de rótulos:

\section{"De preguiçoso, de burro, de tudo o que você pode imaginar."}

Esse massacre, explica Rubens, leva ao desinteresse, pois o "jogo" é idiota e, sabendo ser mais esperto que o jogo, a solução encontrada é burlar as regras para que consiga ir vencendo as barreiras. Sentia-se um "fora da lei", sempre procurando por atalhos. Porém, nenhuma saída parecia resolver seu problema, já que a cobrança vinha de qualquer maneira, tornando sua vida um "massacre constante".

A relação com a língua inglesa é definida como terrível. A forma escrita, tão diferente da oral, mais as dificuldades de memória fazem o aprendizado maçante e, novamente, desinteressante a ponto de ele decidir, na sexta série, abandonar os estudos. Aprender inglês tornou-se uma guerra e Rubens tentou de tudo: o ensino rápido, por internet, tradicional. Três semestres foi o período mais longo que conseguiu estudar em uma escola e explica que o método de repetição era útil, pois auxiliava na memorização, mas tudo se tornou, novamente, desinteressante. A impaciência venceu.

Quando questionado sobre o que mais o deixava frustrado em relação ao idioma inglês, explicou que a leitura era sempre complicada (assim como em português); vocabulário não era muito problemático, desde que aprendido por repetição; ler em voz alta o deixava desconfortável por causa da dificuldade com pronúncia; trabalho em dupla era uma atividade com a qual não tinha problemas, desde que houvesse colaboração; escrita "sempre é problema".

Mesmo depois de saber da dislexia, Rubens preferiu não contar para seus professores. Entendia que teria que vencer as dificuldades impostas por ela e não a usar como muleta. Isso não evitava, no entanto, a frustração.

"Ah, o problema, a sensação com o inglês é um pouco frustrante por não conseguir dominar ele." 
A frustração era a mesma com a língua portuguesa e não conseguir dominar as regras também a tornava desinteressante, sensação que não teve com o idioma espanhol, sobre o qual a narrativa é positiva e leve; declara que foi lúdico e que "aprendeu porque estava a fim de aprender"; "aprendi espanhol porque eu achei várias coisas interessantes no conjunto daquele momento". O momento em questão foi uma viagem a trabalho, na qual viveu o idioma sem se preocupar com ele. Compara as duas línguas da seguinte forma:

"E eu sonho que o inglês podia ser um aprendizado dessa forma, entendeu?"

Rubens retoma a certeza de que é capaz de muitas coisas e chega a achar graça no fato de que não consegue ler português, mas é capaz de ler código cifrado de computador. O sentimento de frustração volta à narrativa.

Sobre a língua inglesa hoje:

"...péssimo. Eu não entendo nada de inglês. Eu sei o básico, muito básico. Não consigo ler, não consigo falar."

Ele analisa esse bloqueio, que chama de trava ou trauma e que aconteceu também com a língua portuguesa, e conclui que o problema se tornou uma questão psicológica.

Ao responder à pergunta "o que é ser disléxico?", Rubens dá a seguinte definição:

"...é como se você vivesse num mundo onde todo mundo se comunica através da música e você não conseguisse aprender a música."

Rubens traz à sua narrativa o que os outros entrevistados também trouxeram: a dualidade de sentimentos que a vida com dislexia carrega. Afirma que a dislexia limita, por um lado, mas, por outro, faz do disléxico alguém sem limites. Discorre sobre achar-se burro enquanto pessoas o acham inteligente, sobre destoar do mundo por não se encaixar no padrão estabelecido e sobre não ter seu potencial aproveitado. 
"Você é um quadrado tentando se encaixar num círculo."

Ele afirma que é o tempo todo assim: o quadrado no círculo. Entende que o ensino pode ser medíocre, mas que não há como fugir; pode tentar se revoltar, deixar de ir à escola, aprender sozinho, mas que é impossível não conviver com o restante das pessoas que seguem o fluxo normal da vida.

"Porque é você contra o mundo." 


\begin{tabular}{|l|}
\hline Oposições semânticas \\
\hline Interesse $x$ Desinteresse \\
\hline Pertencer $\times$ Não pertencer \\
\hline
\end{tabular}

\section{Figuras}

"O quadrado tentando se encaixar no círculo".

\begin{tabular}{|c|c|}
\hline Temas & \\
\hline Busca por um diagnóstico & $\begin{array}{l}\text { Levou sua filha e acabou sendo } \\
\text { diagnosticado também. }\end{array}$ \\
\hline Dificuldades & $\begin{array}{l}\text { Disgrafia, dicção, escrita, leitura, } \\
\text { interpretação de texto, alfabetização, } \\
\text { socialização, confusão, comportamento } \\
\text { perturbador, traumas, frustração, rótulos, } \\
\text { massacre, desinteresse, memória, língua } \\
\text { inglesa, ciências, matemática, português } \\
\text { Não entendia o papel da escola, } \\
\text { sentia-se prejudicado }\end{array}$ \\
\hline Facilidades & $\begin{array}{llll}\text { Língua } & \text { espanhola; } & \text { burlar } & 0 \\
\text { sistema } & & & \\
\end{array}$ \\
\hline Língua inglesa & $\begin{array}{l}\text { Várias tentativas, impaciência, } \\
\text { frustração, trava, questão psicológica } \\
\text { Básico; não consegue ler nem } \\
\text { falar. }\end{array}$ \\
\hline Dislexia/ser disléxico & $\begin{array}{c}\text { Dualidade; não conseguir se } \\
\text { encaixar, destoar } \\
\text { "Você saber que você é capaz". }\end{array}$ \\
\hline
\end{tabular}




\subsection{SABRINA, 30 ANOS, ESTUDANTE DE VETERINÁRIA}

Sabrina tem conhecimento de sua dislexia desde a primeira série, mas o diagnóstico oficial foi apenas há dois anos, pois, segundo ela, "antes eu não queria saber disso". Cansada das reprovações na faculdade, decidiu que era a hora de assumir ser disléxica. Sobre a vida escolar:

"...sempre foi complicada, não reprovei nenhuma, mas sempre tive dificuldade, sempre fiquei de segunda chamada vai, de férias com prova, sempre foi assim, conturbado, nunca passei direto."

Ao responder se estudou inglês fora do colégio, Sabrina imediatamente afirma que nunca estudou "nem dentro da escola", deixando evidente sua grande barreira com o idioma, o qual nunca conseguiu aprender ou entender, independentemente do que fizesse. Refere-se ao idioma como "inglesinho básico", que perdura até hoje, e não ser capaz de aprender inglês fez Sabrina sentir-se estranha. Ela questiona:

\section{"Por que só eu que não consigo inglês? Por quê?"}

Sabrina evita qualquer contato com o idioma - uma das razões para não fazer aulas era que teria que fazer provas, o que, para ela, era ainda pior do que ter a aula em si. O fracasso no aprendizado cria nela uma perspectiva negativa que a impede de sequer tentar.

"Então falei assim: 'não vou fazer porque não gosto, eu não vou passar, nem em primeira fase da escolinha de inglês, então, desencana."

No entanto, mesmo com toda a aversão originada das frustrações com a língua inglesa, Sabrina confessa que quer tentar aprender o idioma mais uma vez assim que terminar a faculdade. Ela sabe que precisa do idioma - menciona a profissão, as leituras da faculdade e o Trabalho de Conclusão de Curso - TCC. Porém, é clara a luta interna que ela trava: 
"...assim que começar a trabalhar, aí quem sabe, eu tente inglês de novo, mas não é uma coisa que 'ah, eu quero. "'

Pensar em voltar a estudar inglês resume-se a uma palavra: tortura. Mesmo tendo acabado de afirmar que poderia voltar aos estudos, aqui ela diz que não quer por ser "muito ruim, péssimo". Na época do colégio, todavia, era pior por ser obrigatório e ter a pressão de depender da matéria para passar de ano. Hoje, a tecnologia e os amigos ajudam a deixar a pressão da necessidade da língua mais leve, apesar de ainda ser importante para todos.

Enfrentar a dislexia significou enfrentar e entender a si mesma:

"...uma hora ou outra eu tinha que enfrentá-la. E aí para viver, para descobrir realmente se eu sou, o que eu sou, o que era...para me ajudar."

Esse enfrentamento teve resultados positivos. O acompanhamento com uma psicóloga e uma psicopedagoga deram a ela a chance de evoluir na faculdade e, em dois anos, ter progressos que nunca havia experimentado. Na escola, lembra que só passou no terceiro colegial porque pediu à professora para fazer uma apresentação no lugar da prova.

Apesar de mostrar uma pequena vontade de estudar inglês, Sabrina confessa acreditar que nunca conseguirá. Sente-se péssima e assustada em relação à língua. Diz não conseguir nem ao menos dizer "what's your name" devido à barreira que criou. Acredita que sempre será uma tortura e, assim como já visto em outras entrevistas, diz preferir a língua espanhola - ou qualquer outra.

Para definir o que é ser disléxico, Sabrina se atém a aspectos negativos de sua condição: problemas de leitura e interpretação e aversão a livros. Ressalta, no entanto, que a tecnologia é um grande auxílio e que a ajudou a ficar menos frustrada com essas dificuldades. 
Oposições semânticas

Vontade x Repulsa

\begin{tabular}{|c|c|}
\hline Temas & \\
\hline Dislexia/ser disléxico & $\begin{array}{l}\text { Enfrentamento da condição. } \\
\text { Tratamento. }\end{array}$ \\
\hline Dificuldades & $\begin{array}{l}\text { Escola (recuperação, segunda } \\
\text { chamada), faculdade (reprovação), } \\
\text { inglês, português, interpretação, provas, } \\
\text { leitura. }\end{array}$ \\
\hline Facilidades & Língua espanhola \\
\hline Língua inglesa & Aversão, tortura, "scary", barreira \\
\hline
\end{tabular}




\section{SOBRE PAIXÕES}

\subsection{O DISLÉXICO E A LÍNGUA INGLESA - AS PAIXÕES ENVOLVIDAS}

O universo das paixões sempre despertou interesse, principalmente na literatura e no cinema. Fiorin lembra esse interesse na Filosofia através do estudo do páthos, por Aristóteles, e dos tratados que buscaram classificar as paixões. Tendo sido considerada até uma patologia, "a paixão opunha-se à lógica: aquela subsumia a loucura, a morte, a obscuridade, o caos, a desarmonia; enquanto esta abarcava o que era da ordem da razão, da vida, da claridade, dos cosmos, da harmonia". Ele afirma que esse olhar para as paixões tem o início de sua mudança no século XVIII, quando "se passa a conceber a paixão como o que impele o homem à ação e o que o eleva às grandes coisas" (2007, p.10).

Na semiótica, o estudo das paixões surge como decorrência natural da análise das estruturas narrativas da ação, que não foram suficientes para compreender um sujeito que não somente age, mas que também passa por estados da alma que "modulam sua relação com a junção (com um dado objeto-valor) e com outros sujeitos" (LARA; MATTE, 2011, p.36). A esses estados da alma deu-se o nome de paixões. Elas podem ser simples, quando se originam de um único momento de modalização do sujeito, como a cobiça - um querer ser - ou complexas, quando são o resultado de um "encadeamento de vários percursos, como a raiva ou a resignação" (FIORIN, 2007, p.5).

Neste capítulo trataremos das paixões simples e complexas que fazem parte do disléxico em sua trajetória com o idioma inglês. Importante ressaltar que os estados da alma fazem parte de um sujeito que, mesmo tendo sua narrativa dividida aqui em fases da vida - escola, aprendizagem de inglês, vida profissional - é, acima de tudo e em todos esses recortes, um sujeito disléxico cujos relatos fundem-se em vários pontos. Nossa tentativa é identificar a relação do indivíduo disléxico com a língua inglesa sem, porém, ignorar o conjunto de suas experiências.

Greimas e Fontanille afirmam que "as paixões aparecem no discurso como portadoras de efeitos de sentido muito particulares; ele exala como que um cheiro confuso, difícil de determinar" (1993, p.21). Importante ressaltar, por exemplo, a questão que Lara e Matte (2011) levantam acerca da confusão muito comum entre "emoção e paixão", principalmente na literatura, quando muitas vezes são usados 
como sinônimos, o que não acontece na semiótica. Para as autoras, emoção é uma "perturbação do comportamento humano", um "conjunto de expressão e conteúdo capaz de gerar efeitos de sentido passionais". Já a paixão modifica o sujeito, pois é um "efeito de sentido de qualificação modal" (p.41). Essa qualificação modal define o sujeito que pode assumir diversos papéis patêmicos - um sujeito que sente raiva, frustração, medo, desejo.

Em outras palavras, ao lado da modalização pelo fazer, que incide sobre a competência modal do sujeito de fazer, qualificando-o para a ação, encontra-se a modalização pelo ser, que dá existência modal ao sujeito de estado, modificando o estatuto dos objetos que estão em conjunção com ele e definindo estados passionais (LARA; MATTE, 2011, p.42).

Frustração é, com certeza, o estado de alma mais frequente nas entrevistas (mas não é o único). Rubens, Marcelo e Ivana referem-se diretamente ao termo, enquanto Sabrina o expressa de outras formas. Barros o descreve:

Explicar uma paixão como a frustração, que se define como "estado daquele que, pela ausência de um objeto ou por um obstáculo externo ou interno, é privado da satisfação de um desejo ou de uma necessidade", significa não apenas dizer que esse efeito passional decorre da combinação do /querer ser/ com o /saber não poder ser/, mas pressupor um percurso narrativo com, pelo menos, duas etapas: a da felicidade ou satisfação, em que o sujeito espera confiante os valores desejados (quer ser e sabe poder ser) e a da frustração propriamente dita, em que o sujeito continua a desejar os valores, mas sabe ser impossível a realização de seus anseios (1990, p.64)

Neste trabalho, identificamos que a narrativa do sujeito disléxico tem como base as relações de conjunção (conexão) ou disjunção (ruptura) com:
a) a escola
b) ser disléxico
c) a língua inglesa 
Ou seja, toda a significação dessas narrativas (paixões, emoções, modalizações) se origina da dinâmica do sujeito com os três itens mencionados acima. Estar em conjunção com a escola pode gerar tranquilidade e satisfação, enquanto a ruptura com esse ambiente, seja ela emocional ou física, pode ocasionar raiva, insatisfação e desinteresse. Estar em conjunção (aceitar-se) com ser disléxico também gera efeitos de sentido diferentes daqueles do sujeito que foge de sua condição. O mesmo se dá com a língua inglesa; a desconexão com o idioma que the é imposto causa uma fuga para outros idiomas, traumas, insegurança. "Logo, se o sujeito de fazer age (transforma estados, alterando a junção - conjunção ou disjunção - do sujeito de estado com os valores), é o sujeito de estado que é afetado, isto é, que sofre as paixões" (LARA; MATTE, 2011, p.42).

As modalidades organizam-se de forma sintagmática (BARROS, 1995, p. 92) - querer-ser, poder-fazer, querer-não-fazer, por exemplo, que causam efeitos de sentido como vontade, liberdade e negação, respectivamente. Ter uma visão clara de como esses sintagmas funcionam é útil para que se entenda o significado e o efeito dos mesmos na narrativa. Silva $(2009$, p.49-50) cita as modalidades, organizadas por Greimas (1966), da seguinte forma:

\begin{tabular}{|c|l|c|c|}
\hline $\begin{array}{l}\text { Modaldades } \\
\text { potencializantes }\end{array}$ & $\begin{array}{l}\text { Modalidades } \\
\text { virtualizantes }\end{array}$ & $\begin{array}{l}\text { Modalidades } \\
\text { atualizantes }\end{array}$ & $\begin{array}{l}\text { Modalidades } \\
\text { realizantes }\end{array}$ \\
\hline crer & querer/dever & saber/poder & fazer/ser \\
\hline
\end{tabular}

Esses quatro tipos de modalidades determinam as duas grandes modalidades conhecidas como intencionais e existenciais e formam "predicados ou enunciados modais" (ou sintagmas): 


\begin{tabular}{|c|c|c|c|}
\hline \multicolumn{4}{|c|}{ MODALIZAÇÕES INTENCIONAIS } \\
\hline \multicolumn{2}{|c|}{$\begin{array}{l}\text { Modalidades virtualizantes } \\
\text { do }\end{array}$} & Modalic & es atualizantes do \\
\hline $\begin{array}{l}\text { querer- } \\
\text { fazer (volição) } \\
\quad \text { querer- } \\
\text { não-fazer (abulia) } \\
\quad \text { não- } \\
\text { querer-fazer } \\
\text { (nolição) } \\
\text { não- } \\
\text { querer-não-fazer } \\
\text { (decisão) }\end{array}$ & $\begin{array}{l}\text { dever- } \\
\text { fazer (prescrição) } \\
\text { dever-não- } \\
\text { fazer (interdição) } \\
\text { não-dever- } \\
\text { não-fazer } \\
\text { (permissividade) } \\
\text { não-dever- } \\
\text { fazer } \\
\text { (facultatividade) }\end{array}$ & $\begin{array}{l}\text { poder-fazer } \\
\text { (liberdade) } \\
\quad \text { poder-não- } \\
\text { fazer } \\
\text { (independência) } \\
\text { não-poder- } \\
\text { fazer (impotência) } \\
\text { não-poder- } \\
\text { não-fazer } \\
\text { (obediência) }\end{array}$ & $\begin{array}{c}\text { saber-fazer } \\
\text { (competência) } \\
\text { saber-não- } \\
\text { fazer (habilidade) } \\
\text { não-saber- } \\
\text { fazer (incompetência) } \\
\text { não-saber- } \\
\text { não-fazer } \\
\text { (inabilidade) }\end{array}$ \\
\hline
\end{tabular}

\begin{tabular}{|c|c|c|c|}
\hline \multicolumn{4}{|c|}{ MODALIZAÇÕES EXISTENCIAIS } \\
\hline \multicolumn{2}{|c|}{ Modalidades virtualizantes do } & \multicolumn{2}{|c|}{ Modalidades atualizantes do } \\
\hline Quer & r / Dever & Pode & r / Saber \\
\hline $\begin{array}{l}\text { querer-ser } \\
\text { (desejo) } \\
\quad \text { querer-não- } \\
\text { ser } \\
\text { (desprendimento) } \\
\quad \text { não-querer- } \\
\text { ser (renúncia) } \\
\quad \text { não-querer- } \\
\text { não-ser (apego) }\end{array}$ & 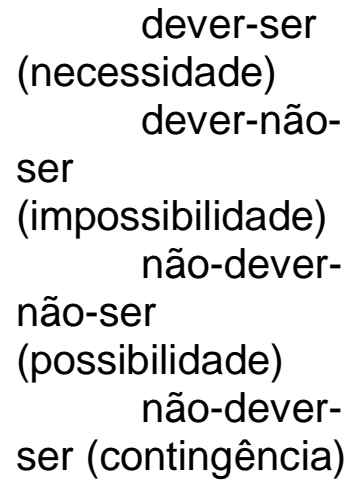 & $\begin{array}{c}\text { poder-ser } \\
\text { (possibilidade) } \\
\text { poder-não-ser } \\
\text { (contingência) } \\
\text { não-poder-ser } \\
\text { (impossibilidade) } \\
\text { não-poder- } \\
\text { não-ser } \\
\text { (necessidade) }\end{array}$ & $\begin{array}{l}\text { saber-ser } \\
\text { (verdade) } \\
\text { saber-não-ser } \\
\text { (falsidade) } \\
\text { não-saber-ser } \\
\text { (ocultação) } \\
\text { não-saber- } \\
\text { não-ser (ilusão) }\end{array}$ \\
\hline
\end{tabular}

As modalidades não devem ser analisadas como "categorias fixas", afirma Calbucci, "mas sim como diferentes equilíbrios do desdobramento da intensidade e da extensidade num campo perceptivo" (2009, p.74). Raiva, ódio, cólera, rancor, aversão podem ir além da simples definição de dicionário e sua força e/ou intenção são investigados tendo como referência a força e o alcance dessas paixões. Fontanille usa o termo "intensividade afetiva", pois o efeito passional é resultado da ligação entre afeto e valor. O que faz alguém chamar um acontecimento negativo de catástrofe enquanto outro chama de incidente? A escolha dos termos acontece em 
"função da intensidade - do impacto" atribuído ao fato (2012, p.206). Ao tratar da extensidade, Fontanille traz o tema da nomenclatura passional. Tanto em português como em francês, temos termos variados como "emoção, paixão, inclinação e sentimento" que "são definidos ao mesmo tempo por uma duração específica e por um certo grau de intensidade" (2012, p.217). O que determina a diferença entre a emoção e o sentimento é a dinâmica entre extensão e a intensidade - quando a extensão temporal cresce e se normaliza, a intensidade, como consequência, é reduzida.

A paixão, entendida como ordenação de modalidades, permite estabelecer uma diferença entre o atualizado (apreensão de um predicado do ponto de vista das condições de realização) e o realizado. A distinção entre querer morrer e morrer reside no fato de que, no primeiro, uma série de roteiros é possível, enquanto no segundo, não (FIORIN, 2007, p.10). 


\title{
3.2. A FRUSTRAÇÃO
}

Frustração é, com certeza, o estado de alma mais frequente nas entrevistas. Rubens, Marcelo e Ivana referem-se diretamente ao termo, enquanto Sabrina o expressa de outras formas. Barros o descreve:

\begin{abstract}
Explicar uma paixão como a frustração, que se define como "estado daquele que, pela ausência de um objeto ou por um obstáculo externo ou interno, é privado da satisfação de um desejo ou de uma necessidade", significa não apenas dizer que esse efeito passional decorre da combinação do /querer ser/ com o /saber não poder ser/, mas pressupor um percurso narrativo com, pelo menos, duas etapas: a da felicidade ou satisfação, em que o sujeito espera confiante os valores desejados (quer ser e sabe poder ser) e a da frustração propriamente dita, em que o sujeito continua a desejar os valores, mas sabe ser impossível a realização de seus anseios (1990, p.64)
\end{abstract}

A dinâmica que leva à frustração em Sabrina difere daquela em Rubens, Marcelo e Ivana. Em uma trajetória de muitas dificuldades com a língua, ela desiste por não acreditar que é capaz; chega à conclusão de que não vale a pena continuar tentando e nem se arrisca a tentar estudar inglês fora da escola.

"Olha, eu fui péssima em inglês; eu não conseguia de jeito nenhum entender como fala, entender como escreve, não adianta, fazer o que fizesse não adiantava. Isso foi na segunda série, eu comecei a fazer o inglesinho lá, básico, até o colegial, até hoje em dia."

"Eu me sentia estranha; por que só eu que não conseguia inglês? Por quê? Eu não conseguia de jeito nenhum, não adiantava."

Quando questionada se tentou estudar fora da escola, responde:

"Não, nem dentro da escola, na verdade."

"Nunca quis tentar na escola porque tinha prova de inglês e prova de inglês para mim era pior do que aula de inglês. Então falei assim: "não vou fazer porque não gosto, eu não vou passar nem em primeira fase da escolinha de inglês, então, desencana." 
Pela insistência de Sabrina em usar a expressão "não adianta", fica a impressão de que a frustração é o motivo de sua desistência depois de várias tentativas e fracassos. "Desencana" remete a "jogar a toalha", "deixar para lá", tentar esquecer o problema.

Rubens sente-se frustrado por não conseguir dominar o idioma, Marcelo por ser colocado em grupos com alunos muito mais jovens que ele e Ivana por não conseguir cantar em inglês.

"Ah, o problema, a sensação com o inglês é um pouco frustrante por não conseguir dominar ele" - Rubens 


\subsection{LUTAS INTERNAS - A OBSTINAÇÃO E O DESESPERO}

A relação do disléxico com a língua inglesa pode gerar grandes lutas internas. O sujeito tem uma experiência negativa com o idioma, mas gosta; ou não gosta, mas precisa estudar; odeia por não conseguir aprender, mas sabe que um dia terá que encarar a situação - e sofre por isso. Vemos um estado de espera que deságua em raiva, medo, insegurança ou resignação. Fontanille e Greimas (1993) tratam das "contradições internas do sujeito" ao compararem obstinação (ou teimosia) e desespero. Em obstinação, estão em jogos as seguintes estruturas modais:

\section{/saber-ser/, /poder-ser/ e /querer-ser/}

Os autores afirmam que "a obstinação, e com mais probabilidade ainda em sua versão modalizada, a "teimosia", o efeito de sentido passional é, sem dúvida, produzido pela confrontação entre um saber que recai ao mesmo tempo sobre uma impossibilidade, de um lado, e um querer indefectível, de outro" (1993, p.67).

Sobre o desespero, que segundo Greimas e Fontanille tem "diferenças mínimas da obstinação", a modalização ocorre com as estruturas modais:

/dever-ser/ e /querer-ser/ x /não-poder-ser/ e /saber-não-ser/

"Em ambos os casos, a modalidade regente é o querer-ser, que pode desembocar tanto numa revolta ou numa depressão, de um lado, quanto num fazer teimoso, de outro" (1993, p.67).

Essas contradições internas percorreram caminhos diferentes na história de Rubens, Renata, Ivana, Sabrina, Marcelo e Tiago provocando resultados também diferentes. É importante, nesse momento, atentar para o fato de que notamos, percebemos e julgamos paixões como obstinação e teimosia, por exemplo, baseados em nossa bagagem cultural. Quem ou o que define a linha que separa os termos? A comunidade discursiva em que o sujeito está inserido.

Tiago e Marcelo traçam uma narrativa similar: ambos conseguiram levar adiante o aprendizado da língua inglesa, apesar de todos os obstáculos. Tiago tem uma trajetória menos intensa e parece ter lidado bem com as adversidades; ao perceber que não daria conta de estudar em escolas, faz a opção da aula particular. Um caminho de obstinação, sem dúvida, mas mais suave do que muitos 
provavelmente esperariam - talvez alguns escolhessem o termo "perseverança" para descrever essa trajetória. Marcelo tem um caminhar mais truncado, menos linear, mas praticamente com o mesmo resultado positivo. A narrativa de Marcelo pode soar mais obstinada devido ao maior número de reveses - e aqui, talvez, estejamos somente impondo nosso julgamento cultural a essa narrativa. Porém, a diferença é que aqui vemos um sujeito que se diz "triste", "vazio" (a ideia de falta) e "frustrado". Retomando Greimas e Fontanille citados logo acima, vejamos se o /querer-ser/ em Marcelo desembocou em revolta, depressão ou teimosia. Parecenos que o confronto de modalidades gerou mais de um caminho: a tristeza e vazio remetem, com certeza, à depressão, mas não podemos negar que a frustração pode ter gerado em Marcelo a teimosia que o fez ir até o fim.

Ivana tem um percurso de obstinação na vida escolar - segundo ela mesma, "era determinada", o que nos leva a colocar determinação no mesmo campo da obstinação. Lia os livros que se propunha a ler, criou estratégias de aprendizagem, fez faculdade. Insistiu em aprender inglês de diferentes formas, mas não teve êxito. Renata e Rubens também cumpriram trajetórias obstinadas em relação à língua inglesa, mas desistiram da escola por um período da vida. A insistência com o idioma, no entanto, também não surtiu bons resultados. Finalmente temos Sabrina, a única que não cumpriu um percurso obstinado em relação à língua; pelo contrário, as dificuldades levaram ao estado de alma de desespero. Quando responde como se sente em relação à língua inglesa, Sabrina diz "Péssima. Very Scary".

O desespero comporta um dispositivo modal do tipo conflitual, no que o querer-ser, de um lado, e os saber-não-ser e não-poder-ser, de outro, coabitam sem se modificarem reciprocamente, contradizem-se e contrariam-se, provocando a ruptura interna do sujeito; também nesse caso o querer-ser não pressupõe as outras modalizações: o desespero é de fato constituído de dois modais incompatíveis; o saber sobre o fracasso e o próprio fracasso não são necessários à aparição do querer, o inverso também não. 0 desespero dispõe, de certo modo, de duas identidades modais independentes, a do fracasso e da frustração, por um lado, e da confiança e da expectativa, por outro; e a ruptura é um efeito de sua independência e de sua incompatibilidade (FONTANILLE; GREIMAS, 1993, p.68). 


\subsection{O RESSENTIMENTO}

Nosso próximo estado de alma é o ressentimento. O disléxico ressente-se na sua trajetória com a língua inglesa?

Como já vimos, muitas vezes é difícil distinguir as paixões. Para Fiorin, "ressentimento confunde-se com a amargura, a inveja, com o rancor, com a decepção e assim por diante" (2007, p.14). O autor também usa a definição do dicionário para buscar uma compreensão mais clara do termo:

Ressentimento é definido pelo Houaiss como "mágoa que se guarda de uma ofensa ou de um mal que se recebeu"; o Robert, como "o fato de lembrar-se com animosidade dos males, das ofensas que se sofreu (como se os "sentisse") ainda" (Ibid).

Fiorin (2007, p.14-15) traça o percurso que leva ao ressentimento, que se inicia com a espera fiduciária. "Um sujeito quer que outro Ihe atribua um determinado objeto, a que ele empresta um grande valor". No caso do disléxico, entendemos que a língua inglesa é esse objeto de valor; mesmo que o indivíduo não tenha nenhuma afinidade ou gosto pelo idioma, aprender inglês é uma imposição e um objeto de valor na sociedade, portanto, algo do qual necessita. Quanto ao outro, estabelecemos ser a escola ou o professor o sujeito que vai atribuir ao disléxico esse objeto de valor. $O$ indivíduo "não apenas quer que o sujeito realize seu desejo, mas crê que ele deve fazê-lo". Acreditamos ser importante apontar aqui que essa espera pelo outro não implica transferência de responsabilidades; os dados que levantamos mostram que o disléxico espera das instituições de ensino/professor um posicionamento eficiente e que dê conta das dificuldades apresentadas por um disléxico para que ele consiga ser bem-sucedido em seu aprendizado, mas não se evade de fazer parte desse processo. A seguir, a incerteza a respeito do cumprimento de algo que o sujeito acha que deve ser feito causa a tensão da espera. A expectativa não se cumpre e ele é tomado pela decepção e pela insatisfação por "saber que é impossível adquirir o objeto desejado". "A decepção não é apenas com o outro, mas também consigo mesmo, que não soube em quem deveria depositar sua confiança". Da junção desses dois sentimentos nasce um grande descontentamento, seguido por um sentimento de injustiça. 


\begin{abstract}
A insatisfação e a decepção são estados terminativos, suscetíveis de transformar-se num sentimento de falta, incoativo. Na medida em que tínhamos duas esperas que conduziram, pela não realização do que se desejava, a um duplo descontentamento (a insatisfação e a decepção), há que distinguir uma falta objetal de uma falta fiduciária. Aquela é a carência do objeto que se desejava; esta é uma crise de confiança. $O$ ressentimento é a consciência aguda e reiterada dessa falta ("o fato de lembrar-se com animosidade dos males, das ofensas que se sofreu (como se os 'sentisse' ainda). No entanto, é preciso notar que ele na verdade não é uma paixão resultante da insatisfação, isto é, da carência do objeto, mas da decepção, ou seja, da falta fiduciária (FIORIN, 2007, p.15).
\end{abstract}

Marcelo fala muito sobre a falta de algo. Sabe que não é falta de inteligência e tenta definir uma coisa que percebe, mas parece a ele ser difícil explicar. "...uma falta de alguma coisa, de algum mecanismo, de alguma ligação que faz com que a pessoa possa entender igual a uma pessoa comum consegue entender uma matéria...". E essa sensação vai repetindo-se ao longo de sua narrativa. Quando lembra de sua dificuldade em entender a fala de um professor, mesmo colocando toda sua atenção "na cara dele", Marcelo afirma que a informação "não entrava"; "faltava realmente alguma coisa", volta a dizer. E essa sensação se estendeu a seu aprendizado de língua inglesa. A parte oral de seu aprendizado ficou prejudicada devido ao vocabulário limitado "porque sempre faltava alguma coisa, sempre faltou alguma coisa". Barros escreve sofre isso:

\footnotetext{
A insatisfação ou decepção, quer ocorram juntas ou separadamente, podem, como se viu, ser determinadas aspectualmente pela duração e prolongar-se em novos efeitos passionais, de mágoa que perdura ou de resignação, por exemplo. Outra possibilidade de desenvolvimento narrativo, também já entrevista, é a da insatisfação e da decepção conduzirem à aflição e à insegurança que, por usa vez, geram sentimento de falta. O sentimento de falta resulta do conflito entre /querer-ser/ e o /saber poder não ser/ e o /crer não ser/. Os efeitos passionais da insatisfação e da decepção são, nesse caso, interrompidos e seguidos de falta que dá lugar a um programa de liquidação da falta (1990, p.66).
}

Fica claro que mágoa não é um desenvolvimento narrativo na história de Marcelo, que tampouco mostrou resignação diante dos obstáculos para aprender um segundo idioma. Barros (1990, p.66) afirma que existem dois tipos de falta: a que se refere à falta de um objeto de valor e outra que diz respeito à falta de confiança (ou 
falta fiduciária). Aqui, vemos a falta de um objeto de valor: a língua inglesa que ele deseja aprender. A liquidação de uma falta pode levar a três caminhos, apontados por Barros: pela continuação da aflição e da segurança, pelo retorno à confiança e pela reparação (p.66). Hoje Marcelo se sente satisfeito com o que conseguiu superar; ao sair da escola, viu-se livre para tentar, a se modo, aprender o idioma. Contando com ajuda, que foi desde o apoio familiar, de professores e médicos até o uso de medicação, Marcelo retomou a confiança em si entrou em conjunção com esse objeto de valor. Não ter a obrigação de aprender, ter contato com nativos, divertir-se com jogos em inglês e até o uso do dicionário deram a ele a chance de /saber poder/ mesmo em meio às dificuldades, possibilitando a instauração de um sujeito de fazer que toma controle da posse de seu objeto de valor:

\section{“...antigamente não tinha esse poder de aprender livremente,} parece que está me facilitando mais também, fora que estou mais velho e tomo remédio que me ajuda a controlar mais também. "

Até aqui concluímos que as etapas do processo que levam ao ressentimento poderiam ser aplicadas aos sujeitos entrevistados: temos a espera por ajuda, traços de insatisfação e decepção e a crise de confiança. Porém, seguindo a linha de raciocínio proposta por Fiorin (2007), percebemos que nenhum desses sujeitos segue o caminho que leva em direção a essa paixão. Abaixo, o quadro com as características do sujeito ressentido apontadas pelo autor e as equivalências encontradas nas entrevistas:

\begin{tabular}{|c|c|}
\hline O ressentido: & Os entrevistados: \\
\hline $\begin{array}{l}{ }^{*} \text { Tem a pretensão de ser mais do } \\
\text { que é. }\end{array}$ & * Sabem de suas limitações. \\
\hline * Apresenta-se como vítima. & * Fogem da vitimização. \\
\hline $\begin{array}{l}* \text { Desincumbe-se de qualquer } \\
\text { responsabilidade. }\end{array}$ & $\begin{array}{l}{ }^{*} \text { Entendem que seus problemas } \\
\text { de aprendizagem trazem consequências. }\end{array}$ \\
\hline $\begin{array}{l}\text { * /quer fazer/ mal ou /quer não } \\
\text { fazer/ bem }\end{array}$ & $\begin{array}{l}{ }^{*} \text { Não mostram nenhum desejo de } \\
\text { vingança e afins. }\end{array}$ \\
\hline $\begin{array}{l}{ }^{*} \text { Tem sentimentos difusos de } \\
\text { ódio, de inveja, de hostilidade. }\end{array}$ & $\begin{array}{l}{ }^{*} \text { Em relação ao aprendizado de } \\
\text { inglês, têm sentimentos variados. }\end{array}$ \\
\hline * Tem desejo de vingança. & $\begin{array}{ccc}* & \text { Têm } & \text { desejo } \\
\text { afastamento/abandono do inglês. }\end{array}$ \\
\hline * É defensivo, frágil. & $\begin{array}{l}\text { * São fortes e lutadores (com } \\
\text { momentos de fragilidade) }\end{array}$ \\
\hline
\end{tabular}




\begin{tabular}{|c|c|}
\hline${ }^{*}$ É lamuriento. & ${ }^{*}$ Reclamam sem lamúria. \\
\hline${ }^{*}$ Cobra reparações o tempo todo. & $\begin{array}{l}{ }^{*} \text { Não levantam a questão da } \\
\text { reparação. }\end{array}$ \\
\hline outros & $\begin{array}{l}{ }^{*} \text { Levantam aspectos negativos da } \\
\text { escola e professores, mas sem inversão } \\
\text { de valores. }\end{array}$ \\
\hline $\begin{array}{l}\text { * Não fala em alto e bom som, } \\
\text { não faz nada claramente. }\end{array}$ & $\begin{array}{l}{ }^{*} \text { Não têm vergonha nem medo de } \\
\text { expor suas opiniões sobre a dislexia. }\end{array}$ \\
\hline
\end{tabular}




\subsection{O MEDO E O PÂNICO}

Fiorin afirma que medo e vergonha "podem derivar de uma sanção negativa" (1992, p.56). Para que se manifestem, é necessário um sujeito de /dever fazer/ em luta com um /não poder não fazer/. Vejamos os dois casos encontrados em nossas entrevistas:

Renata, ao responder à pergunta sobre como se sentia em relação à língua inglesa, diz que a sensação era de agonia e de impotência, e completa:

"Tinha pânico só de falar que ia ter aula de inglês."

Sabrina, para a mesma pergunta, diz:

"Péssima. Very scary! Não consigo nem falar what's your name!"

Ao ser questionada sobre a possibilidade de estudar inglês algum dia, responde de modo direto que não, adicionando que continuará sendo uma tortura e que prefere qualquer outra língua ao inglês.

Renata claramente reage ao /não poder não fazer/ mencionado por Fiorin. Pensar em fazer aula, atividade obrigatória e da qual, portanto, não podia fugir, deixa-a em pânico. Podemos olhar para o medo de Sabrina como uma defesa perante a ideia de que um dia possa precisar do idioma, possibilidade que ela mesma levanta mais à frente.

O sintagma passional do medo diz respeito sempre a algo futuro e encadeia-se como um saber poder estar em conjunção com algo disfórico e não querer estar. [...] Deve-se insistir que há dois tipos de medo: um derivado da possibilidade de uma sanção pragmática negativa (medo dissuasório) e outro de uma performance vista como ameaçadora (FIORIN, 1992, p.57). 


\subsection{QUANDO CULPA E VERGONHA SE MISTURAM}

A linha que divide culpa e vergonha é muito tênue. Diferenças culturais podem alterar a percepção que temos de cada uma; todavia, as duas emoções têm alguns aspectos em comum. Costa (2008) aponta que ambas são negativas, intensas, duradouras e disfóricas e resultam de uma avaliação que o sujeito faz do próprio fracasso ou transgressão. Diferem, porém, em vários aspectos. A vergonha é global, uma avaliação negativa do self, enquanto a culpa focaliza em um comportamento específico; a vergonha traz consigo um sentimento de desvalorização e impotência; a culpa, no entanto, não afeta a identidade central do indivíduo, mas tem a presença da tensão e do remorso. O sujeito envergonhado tem uma mudança de percepção de si, que o leva a diminuir seu próprio valor; o sujeito culpado busca reparação através de desculpa ou confissão e tem o desejo de que a situação pudesse ser revertida ou que seu comportamento tivesse sido diferente (Costa, 2008, p.10).

Tiago, ao justificar a decisão de parar de estudar inglês em uma escola, relata:

\section{"[...[ eu não consegui acompanhar a turma, não consegui passar} na prova, não é? Aí eu pedi desculpa lá na escola. Infelizmente não deu por causa das dificuldades de ensino que tenho."

Tiago sentiu vergonha ou culpa? Sentiu-se envergonhado por seu baixo rendimento e ou se sentiu culpado por não ter atendido às expectativas da escola? Uma coisa sabemos: foi o fracasso que o levou a sair da escola. A avaliação que ele mesmo fez de seu insucesso (não poder fazer) foi a motivação de seu pedido de desculpas e de sua saída.

Harkot-De-La-Taille, ao discorrer sofre o fracasso, analisa o relato de três sujeitos que se sentiram envergonhados depois de abandonarem um projeto de vida. O marinheiro deixa a amada depois de vê-la com outro; o ator desiste da carreira por não ter conseguido convencer seu público; um médico foge depois de certos acontecimentos políticos e do rapto e estupro da filha, fatos que o fazem decidir pela segurança da família. Nesses casos, a vergonha por impotência 
diferencia-se daquela por fracasso porque nesta há a "decisão (ou responsabilidade?) relativa ao abandono do projeto" (1996, p.132).

Finalmente, algumas considerações sobre as diferenças na natureza da vergonha e da culpa levantadas por Costa (2008, p.14-15) podem contribuir para uma decisão mais sólida para nosso questionamento:

Tangney (1994) descobriu que, ao descrever as situações que levam à vergonha, os participantes expressaram uma maior preocupação com as avaliações dos outros acerca do self. Em contraste, ao descrever as experiências de culpa, os participantes estavam mais preocupados com o seu efeito nos outros. Esta diferença entre preocupações egocêntricas versus orientadas para o outro não é uma surpresa, uma vez que, como temos vindo a ver, a vergonha envolve uma focalização no self, enquanto a culpa tem relação com um comportamento específico (Tangney et al., 2007) ${ }^{19}$

Tendo as questões postas, poderíamos concluir que a vergonha fez parte da decisão de Tiago, mas esta foi levada adiante também pela culpa. A preocupação com si mesmo, com o self, é também colocada por Harkot-De-La-Taille quando, ao analisar a vergonha de alguns personagens, escreve que um deles falha em "manter sua imagem de europeu" e "se vê sem identidade" e que "a vergonha de ser visto correndo revela-se, na verdade, uma profunda vergonha por perder a imagem que acreditava ter o direito de gozar [...]" (1996, p.134). Tiago provavelmente se sentiu envergonhado por não conseguir seguir o ritmo da turma e absorver os conteúdos, tendo, assim, sua imagem tocada. Porém, entendemos que, por alguma razão, seu foco sai de si e coloca-se no outro, como se Tiago estivesse em dívida com a escola; não conseguir acompanhar o grupo deixa de ser responsabilidade da instituição e passa a ser dele. Concluímos com Costa (2008, p.11) que afirma "assim, em resumo, enquanto a vergonha motiva a fuga ou o esconder, a culpa motiva uma ação reparadora - confissão, pedido de desculpas e tentativas de desfazer o mal causado".

19 TANGNEY, J.P.; STUEWING, J.; MASHEK, D.J. Moral emotions and moral behaviour. Annual Review of Psychology, 58, 345-372, 2007. 


\subsection{A VERGONHA}

Por fim, chegamos à vergonha, que Houaiss define como:

1. desonra que ultraja, humilha; opróbio; 2. o sentimento desse ultraje, dessa desonra ou humilhação; 3 . sentimento penoso causado pela inferioridade, indecência ou indignidade; 4. Sentimento de segurança causado por medo do ridículo e do julgamento dos outros $[\ldots]$

Harkot-De-La-Taille afirma que a vergonha em "um caráter complexo: trata-se de uma paixão intersubjetiva, originada no cruzamento de outras configurações [...]" (1996, p.10). Neste momento, trataremos da vergonha como "resultante de um fazer do sujeito envergonhado relativo à projeção de uma imagem de si" (p.4). A essa imagem que o sujeito cria de si chamamos de simulacro existencial, ou seja, uma imagem construída e validada por ele e pela qual ele deseja ser representado.

Fiorin afirma que a vergonha existe quando a um sujeito é dado um dever fazer/ser diretamente ligados a um não poder não fazer/ser. Ao não corresponder a essa modalidade, o sujeito pode incorrer em reprovação, que pode vir tanto de si mesmo como de outros, gerando vergonha; a reprovação pode também originar-se devido à falta, no sujeito, de alguma competência que já tenha sido estabelecida no "simulacro de membro de grupo social" (1992, p.57).

Segundo Mello, humilhação e vergonha podem ser considerados sinônimos quando dizem respeito ao sentimento causado no sujeito; humilhação envolve "a ação de quem humilha e o sentimento causado no indivíduo", enquanto vergonha envolve apenas o sentimento (2011, p.95). Porém, humilhação pode significar a ação de humilhar que acaba por levar o outro a ter vergonha e Mello entende que, nesse caso, não é uma paixão, visto que nega o conceito desse estado da alma. Para Harkot-De-La-Taille, humilhação é um tipo de inferiorização e vai além da destruição da boa imagem do sujeito, pois tem efeito de "rebaixamento moral" (1996, p.22). 
Harkot-De-La-Taille (1996) aponta dois tipos de vergonha:

Vergonha retrospectiva: "evento disfórico" que "surpreende o sujeito e o arranca de sua espera relaxada, colocando-o em uma situação intensa, caracterizada pela insatisfação, estado de não conjunção com a "boa imagem", e pela decepção, neste caso, autodecepção, por não ter sido capaz de projetá-la" (p.52). O simulacro existencial é maculado, o sujeito fica confuso, estranha o evento e se vê dentro de um processo no qual esse seu simulacro precisa ser estruturado novamente.

Vergonha prospectiva: a hipótese, baseada em experiências anteriores de vergonha, de ter sua "boa imagem" arranhada "leva o sujeito a estabelecer regras de conduta mais ou menos seguras para si"; a vergonha retrospectiva é virtualizada e o sujeito "desconfia de si mesmo, da sua capacidade de projetar" o simulacro interno da imagem que tem para si mesmo (p.57).

Em nossas entrevistas a palavra "vergonha" não foi usada; nenhum dos sujeitos verbalizou ter vergonha de suas habilidades com a língua inglesa; porém, implicitamente, podemos analisar a possibilidade desse estado de alma.

Marcelo menciona duas vezes que, devido a sua dislexia, precisou regredir no curso de inglês, tendo que fazer aulas com alunos mais jovens. Na primeira menção, quando expressa sua frustração, diz:

"E acabou que um tempo na minha vida eu fui parar, com 16 anos, fazendo turma de inglês com pessoal de 12 anos."

Na segunda menção, um detalhe faz parecer que Marcelo subiu o tom sobre seu desconforto com a mesma situação:

\section{"Então passei uma boa parte da minha vida meio que sofrendo e o} curso de inglês, mais velho, eu voltei a fazer junto com as criancinhas [...]"

O uso da palavra "criancinhas" pode denunciar algo mais que um simples desconforto. Sabemos que adolescentes de 16 anos têm pouco em comum com pré - adolescentes de 12, portanto, ter que fazer aulas com um grupo de alunos tão mais jovens pode ter sido motivo de vergonha para Marcelo. Teríamos aqui um caso de vergonha "retrospectiva" na qual o sujeito tem sua "boa imagem" manchada; ele fica 
insatisfeito pela sua incapacidade de manter essa imagem, que poderia ter ficado mais ou menos preservada se ele, pelo menos, tivesse conseguido fazer aulas com colegas na mesa faixa etária, o que deixaria seu problema um pouco menos exposto.

O segundo caso é com Ivana que, assim como no caso anterior, expressa frustração com a situação que narra. Ivana adora música e sempre quis falar inglês para que pudesse cantar. Quando responde sobre a sensação que tem quando quer cantar e não consegue, exemplifica usando o caso de uma ex-participante do reality show BBB (Big Brother Brasil), que virou motivo de piada no país ao cantar a música "We are the world" com erros extremos de pronúncia. Mesmo não verbalizando que não canta por vergonha, Ivana usa um exemplo claro de vergonha profunda, ou "desonra humilhante, opróbrio, ignomínia, degradação", "humilhação ou rebaixamento diante de outrem" (HARKOT-DE-LA-TAILLE, 1996, p.52) e retrata um caso típico de vergonha prospectiva, na qual a simples hipótese de passar por algo parecido e conhecido (mesmo que não tenha sido experiência própria) a impede de tentar.

As análises das entrevistas para este trabalho mostram casos muito parecidos cujas nuances diferenciam as trajetórias de maneira muito interessante. A seguir, uma visão geral das seis entrevistas com o objetivo de deixar mais acessíveis os dados que distinguem cada uma dessas narrativas. Importante ressaltar que é relevante analisar o quadro mais amplo (experiência escolar) tanto quanto o mais específico (experiência com a língua inglesa), pois um complementa o outro. 


\subsection{PERCURSOS PASSIONAIS DAS ENTREVISTAS}

\section{a) Rubens}

A relação de Rubens com a escola é de disjunção. Se considerarmos que há um contrato fiduciário entre o aluno e a instituição de ensino, para ele esse contrato foi quebrado. A escola, como objeto de valor, perde seu propósito. O sujeito (Rubens) atribui um /dever-fazer/ a outro sujeito (escola), que não cumpriu sua parte no contrato.

"Primeiro, eu não sabia o que estava fazendo na escola, ninguém me dizia o que era para fazer lá, entendeu? E era um negócio confuso, que algumas vezes eu entendia."

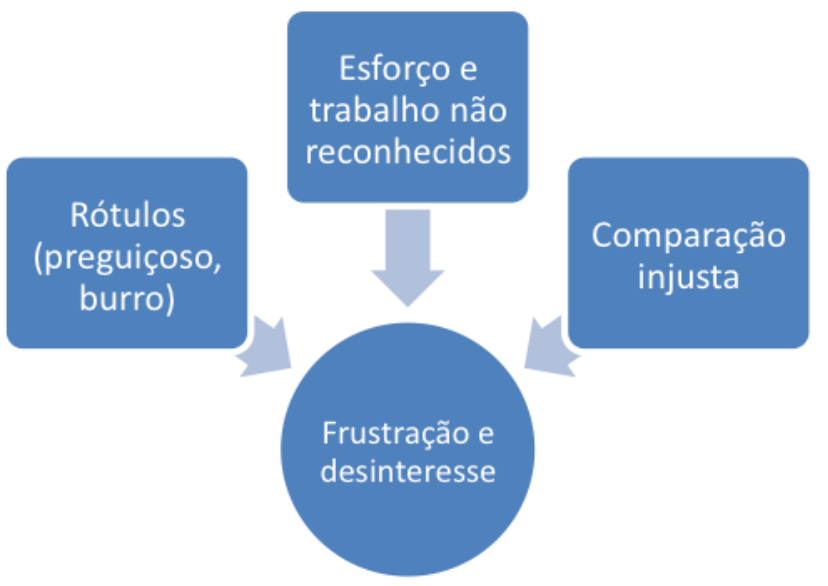

/saber ser/ capaz

"...porque o problema da dislexia, hoje eu tenho essa consciência, na época não tinha, é você saber que você é capaz. E como na escola tudo é medido pelo o que você consegue reproduzir do que você aprendeu, você fica muito prejudicado, não é?"

/saber não ser/ burro e preguiçoso

"E é complicado, aí vêm os rótulos..." 
Sua relação com a língua inglesa:

"Então, inglês foi sempre terrível..."

/não poder fazer/

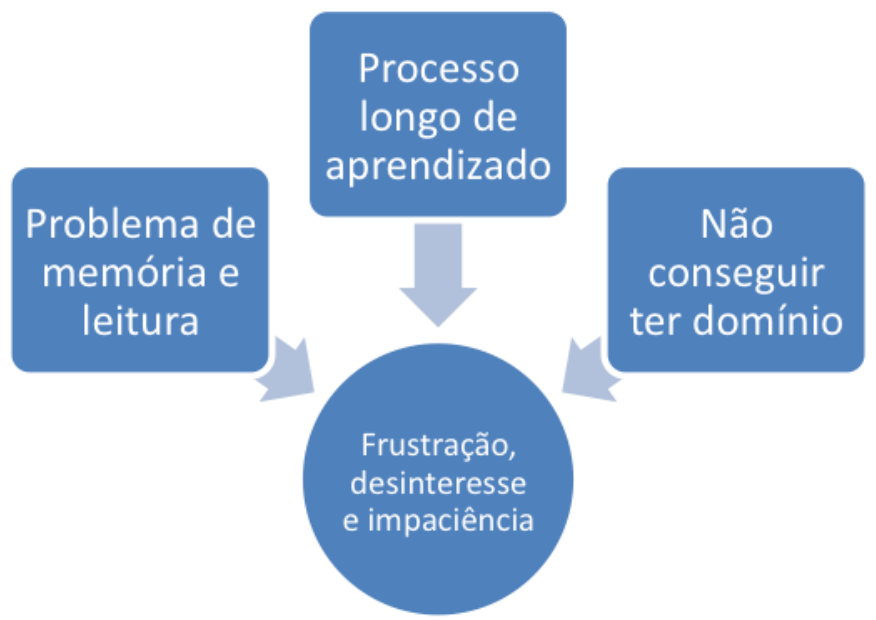

As dificuldades de aprendizagem, mas, principalmente, seu problema de memória, levam Rubens a buscar a aprender inglês das mais diferentes formas: escola, online, métodos que prometiam rapidez no aprendizado - nada funcionou por muito tempo. Segundo ele mesmo, o aprendizado ficava "maçante" e isso, aliado à falta de resultados tornou o cenário perfeito para a frustração, desinteresse e impaciência.

"Não vejo dificuldade nenhuma em aprender inúmeras linguagens e eu desenvolvo vários projetos. É muito engraçado isso. Como eu não consigo ler o português, mas consigo ler quase um código cifrado de máquina sem nenhuma dificuldade? Então o inglês tem, para mim, essa característica parecida com a frustração que eu tive no aprendizado de português." 


\section{b) Marcelo}

$\mathrm{Na}$ escola, a tristeza pela dificuldade em aprender marca a trajetória de Marcelo, um aluno que diz ter fascínio por aprender - "aprender é magnífico" - e que se interessa pelo modo como as coisas funcionam. Aqui, o /não poder fazer/ leva a esse estado de alma.

"Olha, eu te diria, eu me via como uma criança triste, não é? Eu sempre tive interesse em aprender..."

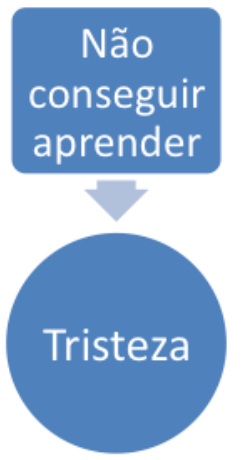

Em seu aprendizado de inglês, Marcelo, assim como Rubens, sente-se frustrado.

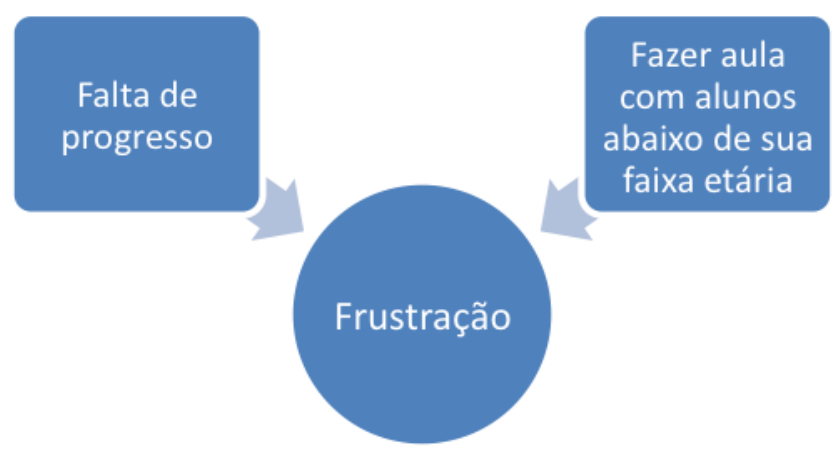




\section{c) Sabrina}

Na escola:

"Sempre foi complicada; não reprovei nenhuma, mas sempre tive dificuldade, sempre fiquei de segunda chamada, vai, de férias com prova. Sempre foi assim, conturbado, nunca passei direto."

Nas aulas de inglês:

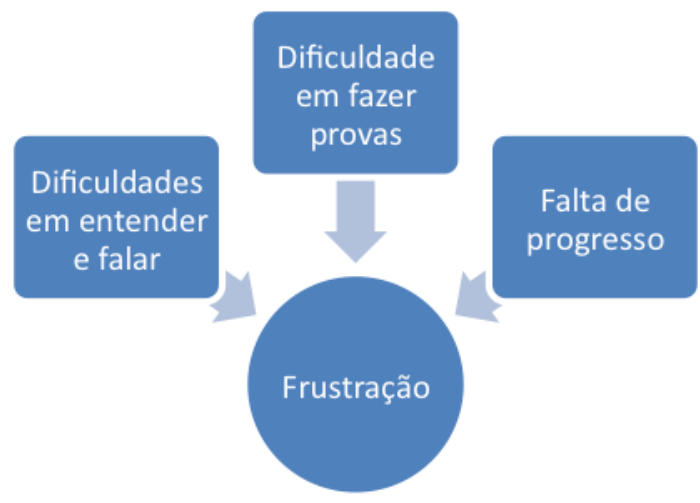

Essa experiência negativa deixou Sabrina em um estado de dúvida: ao mesmo tempo em que afirma que tem vontade de tentar aprender inglês, mostra grande rejeição pela ideia:

"É uma tortura, porque é um sentimento de tortura, não quero. É muito ruim, péssimo."

“Eu não falo inglês, mas tenho vontade. Depois que eu terminar a faculdade, assim que começar a trabalhar, aí quem sabe eu tente inglês de novo, mas não é uma coisa que 'ah, eu quero'”.

Ambiguidade:

Rejeição /querer não fazer/ x Desejo /querer fazer/ 
d) Ivana

Ivana tinha uma postura de perseverança na escola. Sabia que tinha dificuldades, mas buscou por estratégias para lidar com os problemas de leitura. Ainda assim, não ficou imune à frustração gerada pelos obstáculos impostos pela dislexia:

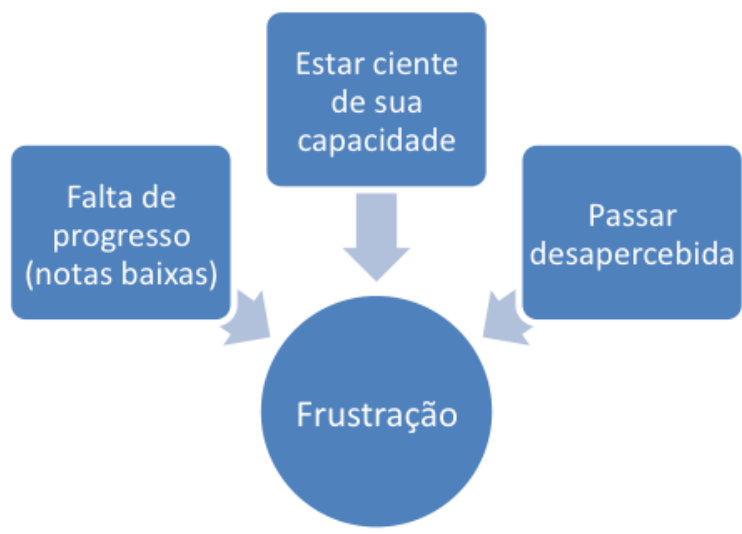

/saber poder/

"Mas eu sabia que podia mais..."

/não poder fazer/

"Porque era uma época em que qualquer erro ortográfico diminuía sua nota. Então, apesar dela (a professora) achar que eu era aluna 10, eu nunca tive um 10 em ciências. Então isso era altamente frustrante."

Sobre o aprendizado de inglês:

Ivana afirma que não ter tido grandes dificuldades e que ia muito bem em inglês, mas, mesmo assim, "não foi pra frente". 


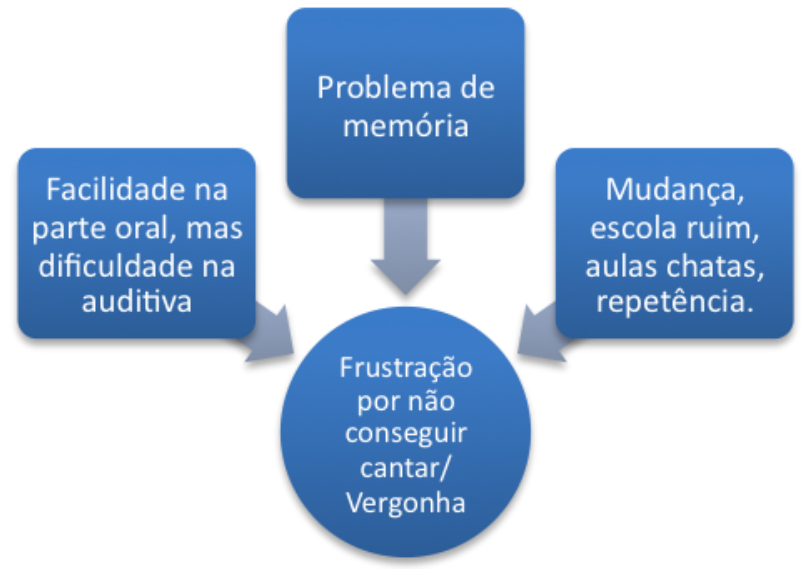


e) Renata

Em relação ao aprendizado da língua inglesa:

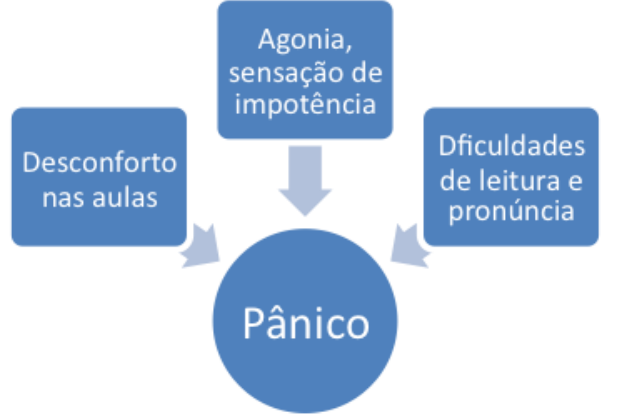

(sobre a língua inglesa) "Eu acho que é parte de mim; eu acho que é apaixonante, porque eu amo música."

(sobre voltar a estudar inglês) "Então, eu vou confessar sério para você: penso. Toda vez que eu ligo o rádio, eu ouço uma música em inglês, eu até penso em voltar, tenho essa vontade. Mas ela passa rapidinho porque eu sei o quanto é difícil para mim. [...] É uma preguiça, uma preguiça inominável." Ambiguidade:

Rejeição /querer não fazer/ x Desejo /querer fazer/ 


\section{f) Tiago}

Tiago tem dois momentos em seu aprendizado de inglês. Na primeira tentativa, em uma escola:

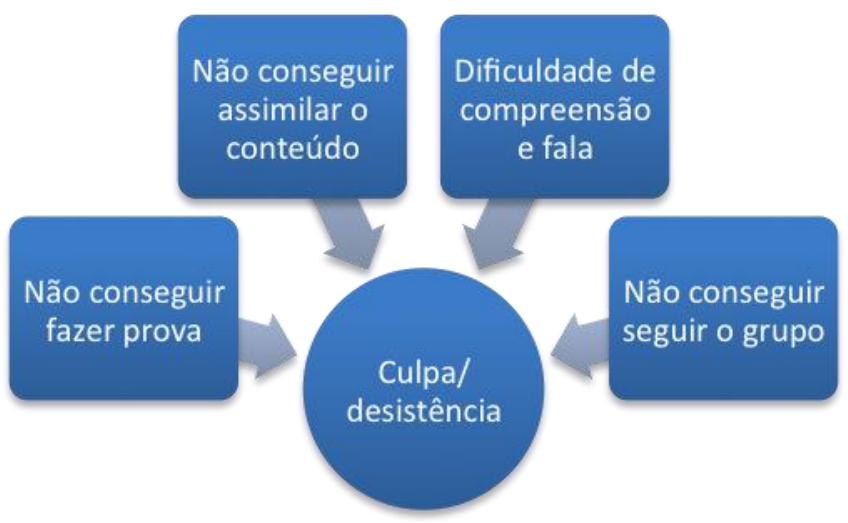

Na segunda, com professor particular:

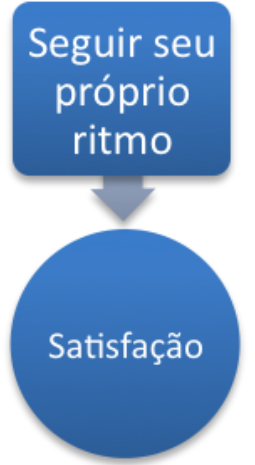




\title{
4. CONSIDERAÇÕES SOBRE COMO AUXILIAR O DISLÉXICO NO AMBIENTE DE APRENDIZAGEM DE LÍNGUA INGLESA
}

Este trabalho não tem como objetivo a análise das metodologias de ensino de língua inglesa; porém, faz-se necessário um breve balanço sobre o assunto, uma vez que ele foi trazido à tona diversas vezes pelos sujeitos entrevistados e também por entendermos que a experiência de aprendizagem não é um ato isolado.

Margaret Crombie (1999), ao tratar do ensino da língua estrangeira nas escolas, afirma que essa é uma oportunidade dada ao jovem de se comunicar com falantes de outras línguas em termos de igualdade, é usar a comunicação para promover entendimento e compartilhar visões de futuro e afirma que, por isso, a promoção do estudo de uma segunda língua vai além de uma teoria educacional ideológica. Ressalta que, uma vez decidido que uma língua será ensinada, devemos nos questionar se temos os meios de providenciar um ensino eficaz e que valha a pena ao aluno.

\begin{abstract}
Até mesmo para aqueles alunos cuja língua nativa tenha alcançado um patamar adequado, o aprendizado de uma língua estrangeira pode apresentar desafios específicos. Além das dificuldades de leitura e ortografia que são normalmente associados à dislexia, há dificuldades em reconhecer padrões da língua que são apresentados oralmente. Isso faz com que a descoberta de padrões lexicais/gramaticais seja difícil ou, algumas vezes, quase impossível, sem intervenções específicas (CROMBIE, 2003, p.x, tradução nossa) ${ }^{20}$
\end{abstract}

Uma vez que o sistema de ensino faz a língua estrangeira obrigatória ${ }^{21}$, o disléxico não tem como se esquivar da experiência. Quer ame ou odeie a língua inglesa, terá que lidar com ela; quer a escola saiba como lidar com suas dificuldades ou não, o disléxico estará presente, trazendo consigo sua bagagem de dificuldades,

\footnotetext{
20 "Even for those students whose native language has reached a very adequate standard, the learning of a foreign language can present particular challenges. Besides the difficulties of reading and spelling that are generally associated with dyslexia, there are difficulties in recognizing language patterns that are presented orally. This makes the discovery of grammatical and/or lexical word patterns difficult or sometimes even impossible without interventions."

${ }^{21}$ A nova lei de Diretrizes e Bases da Educação Nacional prevê Língua estrangeira (inglês/espanhol) como disciplina obrigatória no ensino fundamental a partir da quinta série (www.portal.mec.gov.br/seb/arquivos/pdf/pqcn estrangeira.pdf). Mas em Minas Gerais, por exemplo, "ensino de espanhol é incipiente nas escolas da rede estadual", segundo reportagem de 2015 (www.otempo.com.br/cidades/ensino-de-espanhol-é-incipiente-nas-escolas-da-rede-estadual-1.1020098)
} 
medos e anseios. Damos um passo adiante e nos deparamos com institutos de idiomas, opção comum para alunos com certo poder aquisitivo - não somente disléxicos - cujo objetivo é aprofundar o conhecimento do idioma e/ou reforçar o que aprendem na escola. Não obrigatórios por lei, os cursos de idiomas são uma alternativa normalmente imposta pelos pais, pressionados pelo mundo globalizado que exige a língua inglesa como item essencial de um bom currículo profissional. Voltamos ao já mencionado: essas instituições receberão o aluno disléxico, independentemente de diagnóstico ou de terem estrutura para lidar com as dificuldades provenientes da dislexia. Ao aluno, resta tentar sobreviver à avalanche de obstáculos que enfrentará no percurso.

É imprescindível alertarmos para o fato que aprender inglês é diferente de aprender línguas mais próximas ao português, como italiano e espanhol. Disléxicos tendem a se inclinar para estas línguas com a percepção de maiores chances de sucesso, criando uma barreira ainda maior em relação ao idioma inglês, o que torna ainda mais urgente a necessidade de que esse aluno tenha um entendimento mais claro e objetivo sobre seu processo de aquisição de línguas. Ao entender que a língua inglesa requer estratégias diferentes daquelas exigidas pelo espanhol ou italiano, o disléxico será capaz de avaliar seu progresso e traçar metas de aprendizagem mais realistas.

Com relação à prevalência da dislexia, é muito importante considerar que ela pode variar de acordo com o sistema da escrita, ou seja, sistemas ortográficos mais irregulares, como o inglês e o francês, podem dificultar ainda mais o processo de aprendizagem da língua escrita do que sistemas um pouco menos opacos, como o italiano e o espanhol (ALVES et al., 2011, p.29)

Para que haja uma quebra das barreiras emocionais em relação ao idioma inglês, é também primordial que o disléxico entenda que aprender o idioma pode não ser uma tarefa simples para a maioria das pessoas e que ele não é o único a sofrer. A dislexia, porém, traz um peso extra a algo que poderia ser naturalmente difícil para esse indivíduo. Os índices de proficiência no Brasil são baixíssimos e estamos extremamente mal colocados no ranking mundial de competência em língua inglesa, conforme noticiado pela mídia brasileira. A Revista Exame ${ }^{22}$, em

22 exame.abril.com.br/brasil/fluencia-do-brasileiro-no-ingles-so-piora-ranking 
artigo de 2015, revelou pesquisa realizada pela Education First (EF) com 70 países - o Brasil ficou na posição 41, sendo que vinha mantendo a posição 38 no ranking. A EF avalia "a compreensão gramatical, o vocabulário e o domínio de leitura de adultos" e classifica os países nos níveis "muito alto, moderado, baixo e muito baixo". Lembramos que em pelo menos dois dos itens avaliados os disléxicos teriam uma nota baixa: vocabulário e leitura, como podemos ver no quadro abaixo relacionando as dificuldades apontadas pelos entrevistados:

\begin{tabular}{|c|c|}
\hline $\begin{array}{l}\text { Dificuldades causadas pela } \\
\text { dislexia }\end{array}$ & $\begin{array}{l}\text { Dificuldades causadas pela } \\
\text { dislexia no aprendizado da língua } \\
\text { inglesa }\end{array}$ \\
\hline $\begin{array}{l}\text { - } \text { Lentidão para copiar } \\
\text { - Ortografia } \\
\text { - Disgrafia } \\
\text { - Leitura } \\
\text { - Interpretação de texto } \\
\text { - Interpretação do que ouve } \\
\text { - Desorientação temporal } \\
\text { - Desorientação espacial }\end{array}$ & $\begin{array}{l}\text { - Falta de atenção/concentração } \\
\text { - Vocabulário } \\
\text { - } \text { Audição } \\
\text { - Fazer prova (tempo) } \\
\text { - } \text { Memória/absorver conteúdo no } \\
\text { - } \text { tempo normalmente proposto) } \\
\text { - Fala/pronúncia }\end{array}$ \\
\hline
\end{tabular}

Sentir-se burro, suspeitar ter problemas neurológicos, sentir insegurança, medo, pânico e acreditar que nunca conseguirá aprender inglês são sensações que podem ser dissipadas, ou, pelo menos, amenizadas por esclarecimento, informação e ação. A ação se dá principalmente pelo movimento em busca de formas concretas e eficazes que visam ajudar o disléxico nessa jornada. O Instituto Bright Solutions for Dyslexia disponibiliza uma cartilha cujo objetivo é instruir escolas e professores no caminho da mudança e instalação efetiva de acomodações em sala de aula que trazem enormes benefícios ao aprendizado do disléxico. Essas acomodações referem-se à sala de aula regular, mas, para surpresa de muitos, a maioria das ideias podem e devem ser aplicadas no ambiente de ensino da língua inglesa. A tradução é nossa e buscamos selecionar as acomodações mais relevantes ao 
assunto deste trabalho; caso o leitor tenha interesse pelo assunto, basta acessar o link do $\mathrm{pdf}^{23}$.

Primeiramente, a cartilha explica o que é uma acomodação: "é uma mudança no modo de o professor apresentar a informação, testar alunos e fazer com que seus alunos pratiquem novas habilidades para que cada um tenha a chance de ser bem- sucedido".

Segundo o documento, o aluno disléxico precisa que seu professor entenda sua frustração e entenda que suas dificuldades são provenientes de uma diferença no funcionamento do cérebro. Além disso, esse aluno precisa saber que seu professor não desistirá dele e não fará com que ele pareça estúpido na frente de seus colegas de sala.

Aulas de línguas podem ser muito intimidadoras - não é qualquer um que tem a segurança requerida para falar em voz alta, ir à frente do grupo e dramatizar um diálogo ou fazer apresentações. O mesmo acontece com o disléxico: certas atividades comuns em ambiente de aprendizagem de língua inglesa podem ser um pesadelo para ele. Um professor que compreende essas limitações promove uma atmosfera menos tensa de aprendizagem. Seguem as sugestões:

\section{Para reduzir medo e ansiedade:}

- nunca force um disléxico a participar de competições de soletração ou a ler em voz alta;

- $\quad$ espere que ele se voluntarie para uma atividade.

\section{Para a escrita:}

- não espere que ele tome notas

- entregue suas anotações ao aluno ou permita que ele grave as aulas;

- permitir que o aluno dite para alguém seus textos;

- aceite trabalhos digitados;

- permita uma extensão de tempo para prova escrita e, se necessário, em uma sala especial sem distração (principalmente para alunos

${ }^{23}$ www.dys-add.com/resources/General/AccommodationsHandout.pdf 
TDAH);

- ignore erros de ortografia; não desconte nota;

- permita o uso de dicionários eletrônicos que tenham corretor ortográfico;

- dê alternativas aos trabalhos escritos (vídeo, mural, apresentação).

\section{Para prova oral:}

* grave a prova, permita que o aluno ouça e grave suas respostas.

As sugestões selecionadas são apenas algumas ideias que podem, em muito, ajudar o disléxico em seu desenvolvimento tanto quanto no alívio da pressão que sofrem no ambiente de ensino e aprendizagem da língua inglesa. Como não é o foco de nosso trabalho, deixamos agora esse tema, pois acreditamos serem suficientes as informações aqui contidas. 


\section{ESTEREÓTIPOS}

\section{1. "SERÁ QUE SOU BURRO ?" - O IMPACTO DO ESTEREÓTIPO}

Quando pensamos em estereótipo, quase sempre pensamos em seu impacto negativo. Como aponta Walter Lipmann (2010, p.83), o ser humano parece prisioneiro de um modo de interpretação do mundo. Por conta de sua incapacidade de abarcar todo o universo do qual faz parte, o ser humano acaba interpretando o mundo a partir de outras visões. Harkot-De-La-Taille aponta que o lado positivo do estereótipo é uma "possibilidade de economia muito interessante e necessária à ação cotidiana" que, porém, "coloca um pé na porta para a entrada dos preconceitos", sendo esse seu lado obscuro (2013, p.134). Baccega levanta a interessante questão dos estereótipos originários pelos meios de comunicação, que trazem uma visão de mundo tanto sobre fatos que pertencem a nossa vivência quanto aqueles nos quais não temos participação alguma (1998, p.10).

No universo da experiência humana, podemos, no entanto, tentar nos aproximar de determinadas experiências e até mesmo, em alguns casos, reproduzilas para que possamos construir nossa interpretação dos fatos. Lippmann (2010, p.83) nos relembra que um leigo e um químico provavelmente definiriam a palavra metal de formas diferentes. Igualmente, o disléxico tem uma definição para a sua própria experiência que provavelmente difere tanto daquela do leigo como das definições dos especialistas das diversas áreas mais dedicadas à sua compreensão; na verdade, a definição dessa experiência irá variar mesmo entre os disléxicos.

Inevitavelmente, nossas opiniões cobrem um largo espectro, um longo período de tempo, um número maior de coisas que podemos diretamente observar. Elas têm, portanto, que ser formadas de pedaços juntados do que outros nos relataram e do que podemos imaginar. (LIPPMANN; 2010, p. 85)

É nesse espectro, entre o extremo que aloja o indivíduo que vivencia a experiência em primeira pessoa, família e amigos no meio, muitas vezes tão desorientados quanto o próprio disléxico, e o extremo oposto, onde existem aqueles que se dedicam a estudar tal experiência, que se formam os desafios impostos pela dislexia. É nesse meio que encontraremos a pessoa comum que pouco sabe sobre o assunto, o professor que percebe a dificuldade de um aluno sem saber atribuir-Ihe a 
causa apropriada e o próprio disléxico não diagnosticado, já que para o último a falta de compreensão sobre a própria experiência o coloca em posição semelhante à de um observador leigo com relação as suas dificuldades, que, quase invariavelmente, adquirem a forma de rótulos carregados de estigma e que podem transformar-se em cargas onerosas.

Importante, nesse momento, diferenciarmos estigma de estereótipo. Para Goffman (2013, p.12), a sociedade categoriza os indivíduos e estabelece critérios de normalidade, dentro de cada uma dessas categorias, que devem ser preenchidos; as relações sociais criam uma rotina e, enquanto o sujeito preenche tais critérios, as relações acontecem sem que seja dada atenção a elas. Quando um estranho chega a um grupo, imediatamente ativamos uma busca que nos permita prever "a sua categoria e os seus atributos, a sua "identidade social" (GOFFMANN, 2013, p.12). O que até então acontecia naturalmente, nesse momento torna-se um ato mais consciente, ou seja, as exigências em relação a esse indivíduo vêm à tona. O que é imputado a esse sujeito chama-se identidade social virtual; "as categorias e atributos que ele, na realidade, prova possuir, serão chamados de sua identidade social real" (GOFFMANN, 2013, p.12).

\begin{abstract}
Enquanto o estranho está à nossa frente, podem surgir evidências de que ele tenha um atributo que o torna diferente de outros que se encontram em uma categoria em que pudesse ser incluído, sendo, até, de uma espécie menos desejável [...] Assim, deixamos de considerá-lo criatura comum e total, reduzindo-o a uma pessoa estragada e diminuída. Tal característica é um estigma, especialmente quando seu efeito de descrédito é muito grande algumas vezes ele também é considerado um defeito, uma fraqueza, uma desvantagem - e constitui uma discrepância específica entre a identidade social virtual e a identidade social real (GOFFMAN, 2013, p.12).
\end{abstract}

Para Goffman, as diferenças entre a identidade social virtual e a identidade social real também podem simplesmente reclassificar um indivíduo, ou seja, ele é julgado de modo positivo e é posicionado em outra categoria que tenha sido prevista pelo grupo (p.13). Nesse caso, o sujeito não é diminuído, ele muda de categoria. Como nem todos "os atributos indesejáveis estão em questão, mas somente os que são incongruentes com o estereótipo que criamos para um determinado tipo de indivíduo", o autor conclui que estigma deve ser usado quando se refere a um "atributo profundamente depreciativo" (p.13). 
Miyashiro e Shilling, em artigo sobre filhos de presidiários:

Se o preconceito é algo que emerge nas falas dos entrevistados como algo que incomoda e provoca indignação, o estigma evidencia algo que extrapola uma atitude de prejulgamento, como "sinal infamante, indigno e desonroso, mancha infamante na reputação de alguém" pressupõe a contaminação, o contágio, a transmissão, tornando urgente e necessário o isolamento do agente contaminador (2008, p.248).

A linha divisória entre estereótipo e estigma pode ser tênue, apesar da clara distinção entre os termos, e a teoria pode ser mais simples que a prática. $O$ efeito que um ou outro causam na vida do sujeito talvez seja mais importante do que a definição exata do termo. Os caminhos que o disléxico toma, impulsionado pela pressão, seja do estereótipo ou do estigma, são essenciais para definir sua trajetória. Como explicam Miyashiro e Schilling (2008), "ao aplicar o conceito de estigma, é preciso atentar para o contexto e para a linguagem que permeia a relação dos indivíduos nos diferentes grupos". Para as autoras, a condição de estigmatizado do filho de presidiário será definida pelo "contexto sociocultural e de relações em que essa informação é fornecida ou visível". Usaremos, por isso, a mesma pergunta das autoras, mas dentro do contexto desse trabalho (2008, p. 250): até que ponto ser disléxico é motivo de vergonha, orgulho ou distinção?

As experiências, mesmo quando contam com o testemunho, ou seja, mesmo tendo sido experimentadas em primeira pessoa, abrem espaços para o que Lippmann chama de a transfiguração do evento, em que "o que frequentemente se imagina ser o relato de um evento é, na realidade, sua transfiguração" (2010, p.84). O autor afirma que um "relato é o produto conjunto do conhecedor e do conhecido, no qual o papel do observador é sempre seletivo e usualmente criativo" (2010, p.84) e prossegue lembrando que os fatos que vemos dependem de onde estamos posicionados e dos hábitos de nossos olhos.

Para os colegas de sala, o disléxico pode ser uma pessoa difícil, como no caso de Rubens, cuja colega saiu da turma por não o aguentar. Para o professor, pode ser "preguiçoso, burro, desinteressado"24. Para ele mesmo, uma pessoa normal, como afirmam Tiago e Renata; ou alguém que destoa dos demais, segundo

\footnotetext{
${ }^{24}$ Entrevista feita com a fonoaudióloga Maria Ângela Nico e o psicólogo Luís Gustavo Simi, ambos da
} ABD - Associação Brasileira de Dislexia. 
Rubens. Ivana vê a dislexia como um dom, enquanto Sabrina se define como alguém com dificuldades. Marcelo coloca-se como alguém a quem falta algo. Cada definição dependerá, de fato, de onde cada olhar está posicionado. Para os disléxicos, o modo de olharem para si mesmos dependerá da vivência de cada um, da caminhada que tiveram que percorrer e de como conseguiram ou não superar cada um dos obstáculos impostos pela dislexia.

Essa reflexão, contudo, remete a uma nova dimensão do problema, já que a simples compreensão do fenômeno disléxico, sem que nada se decida fazer sobre como atender o indivíduo, acaba transformando o termo técnico em novo rótulo passível de ser carregado de estigmas. Sem a aplicação do que se sabe sobre a dislexia, esses saberes tornam-se sem efeito e é de extrema importância que os esforços para a correta intervenção ocorram, se não em todas as esferas da vida do indivíduo, como seria o ideal, pelo menos nas esferas onde as dificuldades se fazem mais presentes, como a sala de aula e a sala de aula de língua estrangeira, por extensão.

"Mas no inglês, então, me dava uma agonia, assim, uma sensação de impotência." - Renata

(Sobre estudar inglês): "É uma tortura [...] Não quero. É muito ruim, é péssimo." - Sabrina

" [...] eu não conseguia acompanhar a turma (de inglês), não conseguia passar na prova. Aí eu pedi desculpa lá na escola..." - Tiago

Se compreendermos, como propõe Lippmann, a utilidade do estereótipo para experiência humana, somos confrontados com a existência dos elementos que precisam ser removidos da prática do ensino, por exemplo, para que o disléxico possa ser atendido de uma forma mais adequada.

Um renomado crítico de arte disse que "pelas quase infinitas figuras que uma forma pode assumir... Com nossa desatenção e insensibilidade, as coisas mal poderiam representar e descrever algo que poderíamos lembrar no futuro se não fosse pelas formas estereotipadas que a arte lhes empresta". A verdade é ainda maior que isso, pois as formas estereotipadas emprestadas ao mundo não vêm somente da arte, no sentido da pintura e da escultura, mas de nossos códigos morais e 
filosofias sociais, assim como de nossas agitações políticas (2010, p.86)

Hakot-De-La-Taille afirma que "os estereótipos resistem ao tempo, persistem como normas sobre o que fazer e não fazer, dizer e não dizer, como agir e como "ser" no universo cultural em pauta" (2013, p.130). Conhecer a dislexia, falar sobre ela, esclarecer seus impactos gerais e saber lidar com seus impactos específicos são essenciais para que o disléxico não permaneça à mercê das leituras externas e alheias de uma experiência que é muito pessoal e difícil de ser compartilhada. Apesar de tudo que já foi aprendido sobre a dislexia, a fenda existente entre o conhecimento e sua aplicação permanece e alimenta o que foi expresso em uma de nossas entrevistas.

\begin{abstract}
"Então, começa acho que na escola, começa essa criança já começa a sofrer na escola? É com esses...Que ele é bobo, que ele é preguiçoso, que ele para outras coisas vai bem e os pais chegam contando a mesma coisa em casa também. Ele não quer fazer lição, ele foge da lição, então ele não tem interesse, ele é preguiçoso. Será que ele é burro? E os adultos que chegam, a primeira coisa que eles falam "Será que eu sou burro?" 25
\end{abstract}

Se aqui nos deparamos com o peso dos estigmas operando contra 0 indivíduo, não poderíamos deixar de nos perguntar, por quê, afinal, os estereótipos no caso da dislexia não podem ser apropriados de forma a restituir ao invés de destituir, removendo o disléxico de sua posição incompreendida para uma posição onde fique protegido dos "hábitos do olhar" aos quais Lippmann se refere (2010, p.84)?

Nessa linha de raciocínio, somos forçados a compreender a importância de delimitar o estereótipo, ou estereótipos da dislexia, buscando uma desconstrução que permita, em um segundo momento, propor um novo, ou melhor ainda, o "novo olhar" sobre a dislexia que possa auxiliar em sua detecção e possibilitar um deslocamento do disléxico para uma nova posição onde possa ser melhor acolhido. Para que isso ocorra é preciso que a dislexia deixe de ser apenas uma palavra vazia e passe a ter significado prático e encadeador de ações concretas na prática

\footnotetext{
${ }^{25}$ Entrevista feito com a fonoaudióloga Maria Ângela Nico e o psicólogo Luis Gustavo Simi, ambos da ABD - Associação Brasileira de Dislexia.
} 
profissional de professores e educadores, pois trabalham diretamente com o disléxico nas atividades mais comprometidas pela dislexia. 


\subsection{LETRAS TROCADAS, PEQUENOS SABERES E SUBTERFÚGIOS}

A despeito do quanto já se sabe sobre o assunto, a dislexia continua sendo uma grande desconhecida da maioria das pessoas e mesmo dos educadores. $\mathrm{O}$ desconhecimento, portanto, faz da dislexia um espaço perfeito para que estereótipos, estigmas e preconceitos venham à tona. E, em seu caso particular, não melhor exemplo desse fenômeno do que a crença de que a dislexia se expressa como "troca de letras", por exemplo. É importante salientar que estamos nos atendo aqui ao significado corriqueiro, aquele que existe no imaginário das pessoas e que foi moldado pelo olhar habitual de que fala Lippmann (2010). Não cabe aqui considerar a definição nos dicionários ou mesmo a definição médica de dislexia porque é sobre a visão estereotipada dessa condição que os indivíduos, em linhas gerais, lidam, ou se omitem de lidar.

Na realidade, não é difícil perceber como esse estereótipo serve ao propósito de podermos nos declarar cientes da existência de uma condição especial ao mesmo tempo em que a simplificação excessiva torna a palavra praticamente inútil para que a partir dela se possa desencadear qualquer intervenção positiva sobre o disléxico. Na sua limitação profunda, a crença sobre a dislexia como "troca de letras" tornou-se disseminada e arraigada, mesmo sendo falsa, permite a ilusão de não sermos ignorantes sobre o assunto. Esse é exatamente o tipo de crença de implicações profundas, já que tudo aquilo que recair fora do escopo da troca de letras pode continuar sendo interpretado como falta de inteligência, vontade, determinação ou que quer que seja arbitrariamente estipulado como causa de fracasso de um indivíduo. No caso da dislexia não identificada, o fracasso, quando ocorre, é muito mais imputável ao professor, à escola e a todo o entorno, que falhou em auxiliar o disléxico.

As mais sutis e difundidas de todas as influências são aquelas que criam e mantêm o repertório de estereótipos. Conta-nos sobre o mundo antes de nós o vermos. Imaginamos a maior parte das coisas antes de nós as experimentarmos. (LIPPMANN, 2010, p. 92.) 
Mas Lippmann não se restringe a isso e menciona um aspecto peculiar do processo de estereotipagem, que pelo menos no caso do tratamento da dislexia parece conter uma dimensão adicional.

\begin{abstract}
E estas preconcepções, a menos que a educação tenha nos tornado mais agudamente conscientes, governam profundamente todo 0 processo de percepção. Eles marcam certos objetos como familiar ou estranho, enfatizando a diferença, de forma que o levemente familiar é visto como muito familiar, e o de alguma forma estranho como profundamente alienígena. (2010, p. 92.)
\end{abstract}

Estereótipos, como bem lembra Lippman, são mecanismos de economia de esforço e reflexo de desinteresse. Permitir que a dislexia permaneça oprimida por estereótipos é, portanto, assumir nosso desinteresse pela condição e por todos os que a enfrentam.

Há outra razão, além da economia do esforço, porque tão frequentemente nós sustentamos nossos estereótipos quando perseguimos uma visão mais desinteressada. Os sistemas de estereótipos podem ser os cernes de nossa tradição pessoal, as defesas de nossa posição na sociedade. (Lippmann, 2010, p. 96)

Sobre essa economia de esforço, Baccega (1998, p.8) levanta uma importante discussão acerca da necessidade de se distinguir entre conformidade e conformismo. Para a autora, o indivíduo conforma-se diante do grupo baseando-se em normas e estereótipos para que seja socialmente aceito. Prática comum e inevitável, pois essa economia é o que nos evita entrar em um ciclo infinito de redescobrir o óbvio. A isso ela dá o nome de conformidade. Porém, essa conformidade, que é um componente natural da vivência social, pode enveredar para a estrada do conformismo, que se configura quando "não são oferecidas ao indivíduo/sujeito possibilidades reais de inserção na sua sociedade, numa interação em que ele seja efetivamente sujeito, em que ele tenha voz e sua voz seja respeitada". A autora destaca o papel fundamental da escola nesse momento. Ao disléxico, portanto, se não é dada a oportunidade para que vivencie sua vida escolar de forma plena ou se o ambiente faz com que ele se sinta acuado e incapaz de ter sua voz ouvida, temos configurada a situação de conformismo. 
A sala de aula e o processo de ensino-aprendizagem não estão imunes à necessidade humana de ordenação que acaba facilitando a permanência do estereótipo do disléxico. O lançamento do indivíduo acometido pela dislexia a outros estereótipos de inadequação protege o professor na sua percepção de sua realidade e sua capacidade de lidar com diferentes exigências de aprendizagem. $\mathrm{O}$ mundo a que se refere Lippmann não exclui a sala de aula.

Naquele mundo as pessoas e as coisas têm seus lugares bem conhecidos, e fazem certas coisas previsíveis. Sentimo-nos em casa ali. Enquadramo-nos nele. Somos membros. Conhecemos o caminho em volta. Ali encontramos o charme do que é familiar, o normal, o seguro; seus bosques e formas estão onde nos acostumamos a encontrá-los. (2010, p. 96)

O estranho, portanto, abala a sensação de familiaridade do grupo, que muitas vezes não percebe o sentimento de inadequação desse estranho. Rubens decidiu sair da escola por não ver sentido em estar ali, chegando à conclusão de que a escola não servia para nada; da mesma forma, Renata aceitou que nunca aprenderia nada, o que também a motivou a largar a escola. A falta de segurança e de ligação com o grupo levaram os dois a uma decisão radical e sair desse espaço desconfortável pareceu ser a melhor decisão.

Esses conceitos vagos e de conhecimento de todo professor produzem poucos efeitos concretos. Ainda que professores monitorassem ativamente suas salas de aula para detectar a presença de possíveis alunos disléxicos, se suas observações forem dependentes apenas desse olhar habitual incompleto, as chances de localizar alguém que precise de auxílio são próximas de zero. Essa predefinição impede que vejamos aquilo que está diante de nós e ela é confortante na medida em que a partir daí, nada mais precisamos fazer.

Na maior parte dos casos nós não vemos em primeiro lugar, para então definir, nós definimos primeiro e então vemos. Na confusão brilhante, ruidosa do mundo exterior, pegamos o que nossa cultura já definiu par nós, e tendemos a perceber aquilo que captamos de forma estereotipada para nós e nossa cultura. (LIPPMANN, 2010, p. 85)

Sem se equipar professores com o correto entendimento do espectro completo do problema, falar de dislexia passa a ser somente um exercício de 
aparente preocupação. A posição é confortável, já que permite uma encenação de inexistência do problema em sala de aula mesmo quando diante do aluno disléxico, já que com frequência, ou disléxico não foi diagnosticado ou prefere, por conta do ônus imposto, permanecer calado sobre as causas de suas dificuldades.

"Eu não cheguei a informar, a falar que tinha deficiência porque eu queria provar para mim mesmo que eu era capaz de alguma coisa..." - Tiago (sobre informar a escola) "Não, acho que nunca me veio essa preocupação; para mim já estava meio acomodado, que eu teria mesmo que vencer a dificuldade e não usar a dislexia como muleta." - Rubens

Como se pode depreender, saber pouco sobre dislexia talvez seja pior do que não saber nada sobre ela. O pouco saber, na realidade, uma mera máscara para um estereótipo, protege o professor, a escola, as empresas e as instituições de terem que lidar, verdadeiramente, com o disléxico. Aliás, com frequência, esquecemo-nos de que o disléxico não habita somente o ambiente escolar, mas transita pelo mundo que dele exige leitura e interação, atividades essas que são comprometidas e que exigirão dele estratégias de sobrevivência para lidar com as tarefas do dia a dia, que vão das colas de cheques às múltiplas redações escritas de antemão para serem utilizadas em uma entrevista de emprego, como relatado nas entrevistas dos profissionais da $A B D$. Tais exemplos dão testemunho contundente da recusa da sociedade em de fato emprestar um novo olhar para melhor atender o disléxico mesmo quando esse se apresenta como tal.

O estereótipo, assim como o conceito, é um reflexo/refração específica da realidade - ou seja, reflete com desvios, como um lápis que, colocado em um copo de água, "entorta" -, mas o estereótipo comporta uma carga adicional do fator subjetivo, que se manifesta sob forma de elementos emocionais, valorativos e volitivos, que vão influenciar o comportamento humano. Ele se manifesta, portanto, em bases emocionais, trazendo em si, como já dissemos, juízos de valor pré-concebidos, preconceitos, e atuam na nossa vontade (BACCEGA, 1998,p.10).

A figura do lápis dentro do copo com água define perfeitamente como o disléxico pode ter que viver à sombra dos estereótipos. Sente-se e sabe-se inteligente, mas é visto como burro. Quer aprender, mas é visto como 
desinteressado. Ele próprio chega a duvidar de sua capacidade, como Renata, que pensava ter problemas neurológicos. As questões emocionais somam-se à desvalorização do indivíduo, situação, segundo Baccega, grave, pois o "estereótipo é usado como se fosse apenas um conceito e a carga negativa fica dissimulada". A autora cita, como exemplos de dissimulação, desde as injustiças cometidas contra negros e índios até as formas modernas de "discriminação e exclusão" (1998, p.10). Harkot-De-La-Taille também alerta para o "lado obscuro" da estereotipagem, que é "um pé na porta para a entrada dos preconceitos" (2013, p.134).

No que tange a preconceitos, a Fundação Instituto de Pesquisa (Fipe) divulgou em 2011 uma pesquisa realizada em 501 escolas públicas no Brasil:

De acordo com a pesquisa, os tipos de preconceito que apresentam maior abrangência são aqueles relacionados a pessoas com necessidades especiais (96,5\%), seguido por diferenças étnico-raciais $(94,2 \%)$ e aqueles relativos a diferenças de gênero (93,5\%). Além disso, assim como o preconceito, percebeu-se entre todos os públicos-alvo da pesquisa uma predisposição em manter menor proximidade em relação a determinados grupos sociais, como homossexuais, pessoas com necessidades especiais de natureza mental e ciganos" (JAHN, 2011)

Portanto, fica claro que é de extrema importância que a dislexia seja entendida em todos os seus aspectos. O preconceito é mais um entre os vários problemas enfrentados pelo disléxico; quanto mais claras forem as informações, quanto mais abertamente o assunto for discutido, maiores as chances de sucesso na luta por uma inclusão escolar e profissional eficaz e produtiva desse indivíduo. 


\section{RECONHECIMENTO}

\section{1. "RECONHECI-ME COMO DISLÉXICO"}

Emprestamos e parafraseamos a frase de Rimbaud citada por Ricoeur ( $p .83$, 2006), "Reconheci-me como poeta". Faço-o para chamar a atenção ao que talvez seja uma das constatações mais relevantes deste trabalho: o disléxico, ao contrário do que muitos possam pensar, geralmente não quer fugir de sua dislexia percebemos que a fuga, com frequência, acontece mais pelos traumas e decepções causados por uma condição não compreendida do que pela dislexia em si. O diagnóstico é fonte de alívio, pois não entender a razão por trás de suas dificuldades torna a vida intrincada e cheia de pontos de interrogação. O depoimento de Flávia no blog "Estudo da Dislexia" exemplifica muito bem esse sentimento:

Meu nome é Flavia tenho 18 anos moro com meus pais e irmãos, sou disléxica e toda minha família é também, imaginem: Meu pai é disléxico se juntou com minha mãe que também é disléxica e deu quatro filhos disléxicos e eu sou a caçula, carregando o histórico nas costas, e vocês devem saber muito bem como é complicado ser disléxico numa sociedade em que vivemos, sofri muito tive várias crises comigo mesma principalmente na pré-adolescência em que começou a me machucar e incomodar os meus erros ortográficos, aí então começou o meu dilema de não saber escrever. (...) Mas eu digo que minha vida mudou da água para o vinho quando eu descobri a dislexia, me veio uma mistura de sentimentos tais como alegria, emoção, curiosidade, solução de tantas coisas, o meu coração disparava eu não piscava os olhos eu refletia bastante tudo era muito novo para mim um mundo que até então eu desconhecia, eu lamentavelmente descobri através de um programa de TV coisa que poderia saber desde pequena, mas não culpo meus pais não, pois foram vítimas assim como eu (...) (grifo nosso)

Dos entrevistados para este trabalho, nenhum deles manifestou qualquer tipo de rancor em relação ao fato de ser disléxico. Os sentimentos negativos relatados são provenientes das dificuldades oriundas da dislexia, da falta de apoio e conhecimento, em ambientes de aprendizagem, do que ser disléxico significa, e também da falta de formas de intervenção eficazes. Reconhecer-se, portanto, como disléxico, tem um papel importante na história desses indivíduos, pois o momento desse reconhecimento é um marco que influencia profundamente suas trajetórias. 
Marcelo, assim como Flavia, usa o a expressão "mudou da água para o vinho" para referir-se à transformação do seu aprendizado depois de uma intervenção bem- sucedida, que uniu tratamento e medicação. Ele afirma que saiu do impossível para uma vida na qual o aprendizado se tornou algo "mais fácil de alcançar". Reconhecer-se como disléxico contribuiu para que Marcelo buscasse soluções para os problemas que enfrentava, já que não dedicou sua energia a negar sua condição.

O diagnóstico tardio pode ocorrer tanto por falta de acesso a profissionais e não entendimento dos sintomas por parte de pais e professores quanto por decisão do próprio disléxico. Ivana fugiu o quanto pôde e o laudo oficial, já adulta e atuante como fonoaudióloga, não foi uma experiência fácil. "Foi sofrido porque eu fugia", diz ela. No entanto, esse processo de reconhecimento teve início na faculdade, quando também fugia de situações nas quais tivesse que encarar a dislexia; ela evitava, a todo custo, os pacientes de leitura e escrita. Reconhecer-se no outro, para ela, era tão difícil quanto reconhecer a si mesma. Quando não pôde mais escapar - seu paciente foi sorteado e era exatamente de leitura e escrita - Ivana foi forçada a encarar suas questões. Da experiência, que foi positiva, tirou bagagem para a vida. Entendemos, portanto, que se reconhecer não é somente um processo intelectual, mas cognitivo, que envolve, entre outras coisas, percepção e juízo. Mesmo tendo vivido uma experiência que possibilitou um desprendimento de seus medos, Ivana ainda levou tempo para ter coragem de oficializar o que já sabia. Reconhecer-se, nessa história, foi um processo não linear.

A descoberta da dislexia pode também acontecer inesperadamente. Rubens e Renata passaram por uma situação recorrente nos consultórios e associações: buscaram ajuda para os filhos e foram diagnosticados durante o processo. Rubens, há mais ou menos 14 anos, após ler reportagens sobre o assunto e assistir a uma entrevista da fonoaudióloga Maria Ângela Nogueira Nico, da ABD (Associação Brasileira de Dislexia), decidiu levar a filha de 5 anos a uma psicóloga. Lá chegando, deixou a filha de Rubens para mais tarde para que pudesse concentrar-se nele. Renata, aos 37 anos, fez o teste junto com o filho. Tanto para Rubens quanto para Renata, reconhecer-se disléxico compreende a aceitação de qualidades e defeitos, de diferenças que os fazem destacarem-se em algumas áreas e terem dificuldades em outras. Renata, que buscou ajuda com terapia, hoje entende a dislexia como uma de suas "desabilidades"; desabilidade de uma pessoa normal. 
Tiago descobriu sua dislexia jovem ${ }^{26}$ e apresenta um quadro comum entre os disléxicos, que é o de indivíduos que apresentam comorbidades associadas: tem DDA (Distúrbio de Déficit de Atenção) e agressividade. Priscila S. Martins, da UFRJ, em artigo disponível no site da Associação Brasileira do Déficit de Atenção, afirma que "a taxa de comorbidade entre TDAH (Transtorno de Déficit de Atenção com Hiperatividade) e Dislexia é elevada e bidirecional (25 a 40\% apresentam sintomas do outro transtorno, independente do inicial). Esta associação, muito estudada, envolve complexos mecanismos que são compartilhados por estes transtornos (genéticos, ambientais, comportamentais, cognitivos, etc.)". Tiago não demonstra dificuldades em se reconhecer como portador de dislexia, tanto que não hesitava em contar para os colegas para defender-se da zombaria quando cometia erros de ortografia. As brincadeiras relativas a seus erros o chateavam, não a dislexia em si.

Sabrina descobriu sua dislexia na primeira série, mas isso não impediu que tivesse dificuldades na escola. Também não se reconhecia como disléxica; segundo ela, até conhecer a Associação Brasileira de Dislexia, ela "não queria saber disso". Os problemas de aprendizagem, que se intensificaram na faculdade, foi o motivo que a levou a buscar ajuda. Reconheceu-se por não ver outra saída - ou enfrentava a dislexia ou seria vencida por ela.

\footnotetext{
${ }^{26}$ Há uma inconsistência quanto à época em que Tiago descobriu sua dislexia. Na primeira menção, dá a entender que foi no início de sua alfabetização. Mais tarde, afirma que foi pelas redes sociais. Pode-se deduzir que recebeu o diagnóstico quando pequeno por causa da troca de letras e, mais tarde, confirmou o diagnóstico através de informações colhidas na internet.
} 


\subsection{O PERCURSO}

Em seu livro "Percurso do Reconhecimento", Ricoeur (2006) aborda o tema em três estudos que foram originados a partir de um levantamento dos vários sentidos da palavra "reconhecimento". Na primeira parte, "O reconhecimento como identificação", Roger-Pol Droit (2004) afirma que o autor distingue, "no fluxo permanente das aparências, a permanência de uma identidade, seja ela a de uma substância, de uma forma ou de um conceito. Reconhecer é então reencontrar nos objetos ou nas pessoas os traços de uma consciência que os fazem familiares a nós". No segundo estudo, "Reconhecer-se a si mesmo", Droit explica que Ricoeur trata dos processos que nos levam a um entendimento de nossa identidade:

Ricoeur desenvolve uma rica e original análise da identidade
concebida como capacidade. O que me define é aquilo de que sou
capaz. É nisso que me reconheço e que me reconhecem, é o que
posso contar de mim, é também o que define a dimensão ética de
minha responsabilidade, do que me é imputável, do que posso
prometer. Nessa questão da capacidade se inserem igualmente as
práticas sociais e a constituição das identidades coletivas. (lbid.)

Na terceira e última parte há o estudo chamado "O reconhecimento mútuo", sobre o desejo de ser reconhecido pelo outro, que tem, também, a mesma ânsia de ser reconhecido.

Em entrevista a Roger-Pol Droit (2004), Ricoeur fala sobre sua busca pelas definições de "reconhecer" presentes no Dictionnaire de la langue française (Émille Littré) e no Grand Robert de la langue française. Droit relembra que só o primeiro dicionário exibe vinte e três sentidos, sendo os mais comuns "ter no espírito a ideia de uma pessoa ou coisa que já se encontrou", "autenticar o que jamais se viu" e "descobrir uma verdade"; afirma também que o Grand Robert foi capaz de atingir mais objetividade, condensando o termo a três sentidos principais: "ligar imagens e percepções relativas a um objeto para distingui-lo", "considerar verdadeiro" e testemunhar gratidão". Vejamos como alguns dicionários tratam desse termo na língua portuguesa:

Houaiss (2209): "ação ou efeito de averiguar; exame, verificação; aceitação da legitimidade de (governo, culto etc.); recordação de benefício recebido, gratidão; 
aceitação de uma obrigação; ato através do qual alguma coisa é admitida como verdadeira, ou se declara quem é certa pessoa, identificando-a".

Site Conceito.de: "...acto de examinar algo ou alguém com atenção; registrar para conhecer seu conteúdo, confessar alguma situação ou aceitar um novo estado das coisas".

Dicionário Infopédia: "gratidão, agradecimento; ato ou efeito de reconhecer; identificação de algo ou alguém já conhecido, recompensa, prêmio; ato de reconhecer o mérito, valorização; aceitação como legítimo ou verdadeiro; ratificação; PSICOLOGIA momento de um ato da memória em que o espírito identifica o objeto de uma representação (percepção ou lembrança) com um objeto anteriormente percecionado".

Ricoeur (2006) destaca que "reconhecimento" em francês (reconaissance) tem uma multiplicidade de sentidos, o que também acontece em português (verificação, aceitação, gratidão etc.), sendo assim, de significação mais ampla do que o termo em alemão Anerkennung, da Teoria do Reconhecimento de Hegel, ressaltam De Caux e Valente (2010). Sobre Anerkennung, Lawrenz (2007, p.155) escreve:

O mundo que é o conteúdo das mentes é formado por essas interações ${ }^{27}$; mas enquanto objetos meramente resistem, e em sua resistência impõem forma ao mundo subjetivo, outras mentes fazem isso por meio de complexas influências intersubjetivas que exigem de ambos os lados o reconhecimento (Anerkennug) de inúmeras características sociais, intelectuais, espirituais, emocionais e materiais nas quais humanos em sociedade estão envoltos"28 (tradução nossa)

O percurso ao reconhecimento de si como disléxico dos aqui entrevistados possuem uma espinha dorsal comum, como podemos ver nos esquemas logo abaixo:

\footnotetext{
${ }^{27}$ interações: o autor refere-se ao choque entre o que chama de "objetos externos", sendo vontades um dos exemplos.

28 "The world which is the content of minds is formed by these interactions; but whereas objects merely resist, and in their resistance impose shape on the subjective world, other minds do this through complex intersubjective influences which demand on both sides the acknowledgement (Anerkennung) of innumerable social, intellectual, spiritual, emotional and material features in which humans in society are enveloped:"
} 

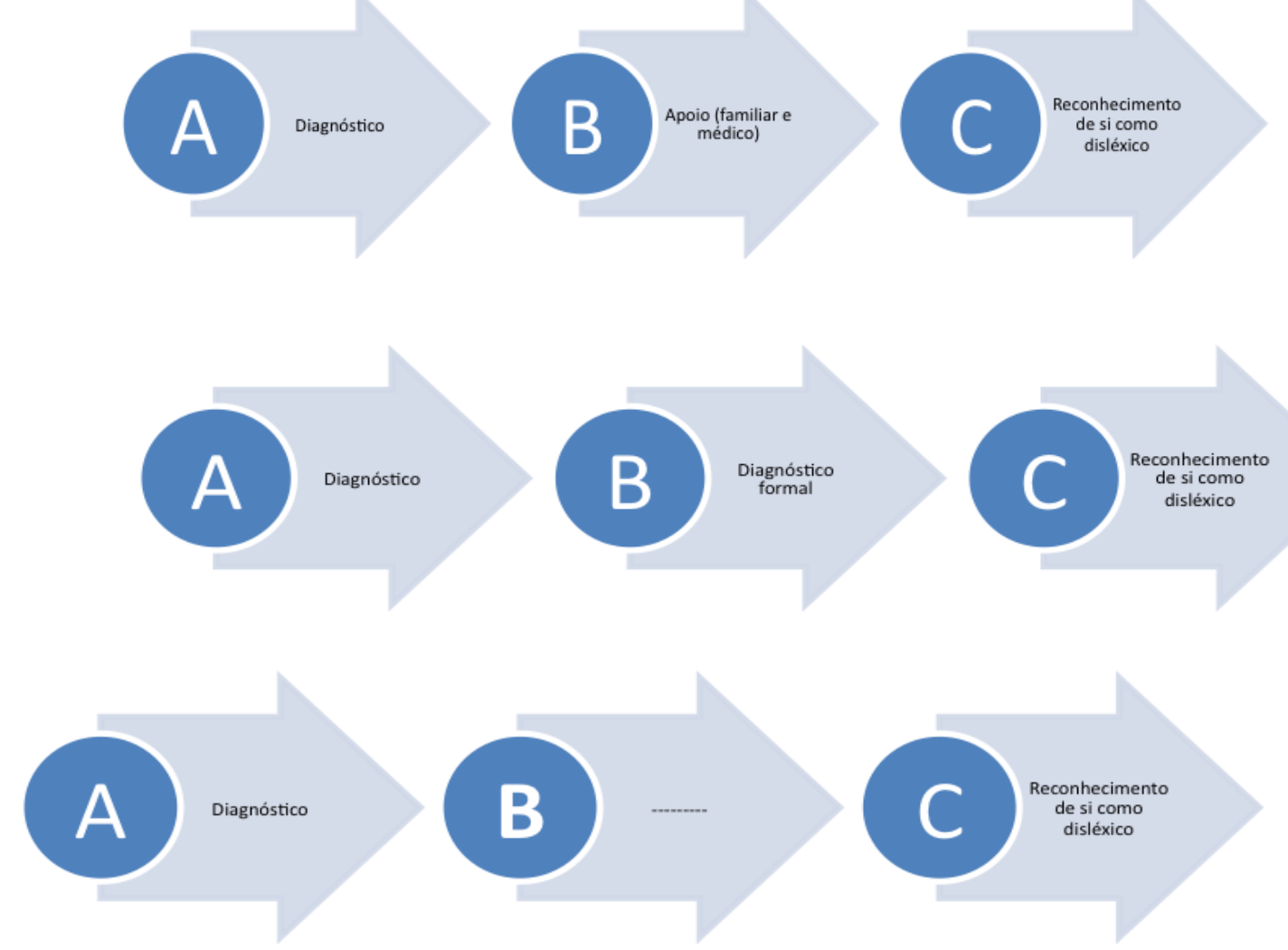

Ter o diagnóstico como ponto inicial para o processo de reconhecimento pode parecer uma necessidade incontestável; porém, compreender o papel dele dentro desse processo traz um entendimento mais profundo sobre todo o percurso. Temos três caminhos distintos nas histórias relatadas. No caminho (A), um diagnóstico amparado pelo apoio familiar e médico, que pode incluir tratamento e medicação, propiciou aos indivíduos a base da qual precisavam para lidar com sua condição e, consequentemente, as dificuldades trazidas por ela. Na situação (B), o primeiro diagnóstico mostrou-se insuficiente; ambos os entrevistados relatam fuga e tentativas de não lidar com a questão até que, por diferentes razões, cederam a um diagnóstico oficial, que levou ao reconhecimento da dislexia. Finalmente, no caminho (C), o que percebemos é um percurso mais direto, no qual o reconhecimento veio como consequência do diagnóstico. Vemos, portanto, que um laudo pode exercer tanto um papel de simples averiguação quanto de averiguação para que o fato conhecido possa ser legitimado. Diagnosticar, por isso, não significa sempre legitimar. A legitimidade acontece via reconhecimento: reconhecer-se é 
legitimar-se naquela condição. É uma criatura racional postulando-se como indivíduo entre outras criaturas racionais (LAWRENZ, 2007, p.155) ${ }^{29}$.

Sobre a luta pelo reconhecimento, Ricoeur (2006, p.198) reforça a relação da presença dessa ligação entre o si e o outro - a reciprocidade do reconhecimento mútuo - que caracteriza o conceito de Anerkennug de Hegel. Percebemos neste trabalho a importância da dinâmica "reconhecimento de si" $\Leftrightarrow$ "reconhecimento pelo outro" e como a dinâmica entre essas duas instâncias determina o percurso do indivíduo que busca se aceitar.

Tomando como fio condutor a distinção entre os usos do verbo
"reconhecer" na voz activa ("eu reconheço"), que expressa o domínio
do pensamento sobre o sentido, e na voz passiva ("eu sou
reconhecido"), que exprime a exigência de ser-se reconhecido,
desenvolve-se uma dinâmica que, do "reconhecimento-identificação"
(do "qualquer coisa" e do "qualquer um" em geral), fase em que o
verbo "reconhecer" quase não se distingue do "conhecer", passando
pelo reconhecimento de si-mesmo do si nas capacidades e poderes,
conduz a uma situação de reconhecimento mútuo, na qual os
sujeitos se encontram numa relação de reciprocidade. (SALDANHA,
2009, p.22)

A dialética entre identidade e alteridade é um dos três aspectos da "hermenêutica de si" de Ricoeur (2006). Houaiss define hermenêutica como "ciência, técnica que tem como objeto a interpretação de textos religiosos ou filosóficos; interpretação dos textos, dos sentidos das palavras". Uma hermenêutica de si, portanto, é o ato de decifrar, entender, interpretar a si mesmo. Tourinho (2014, p.6) explica que Ricoeur "estendeu a noção de texto para todas as objetificações da existência humana"; a vida é um texto cujo sentido pode ser explicado. "O problema da leitura e compreensão de um 'texto' se torna uma nova metáfora para todos os tipos de compreensão, incluindo a compreensão dos fenômenos sociais e culturais". A dialética com o outro, com o mundo, com outros 'textos' e outras realidades propicia ao sujeito, portanto, a reflexão que conduz a um entendimento de si mesmo.

${ }^{29}$ Lawrenz citando Fichte, Grundlage des Naturrechts. 


\subsection{O SUJEITO CAPAZ}

Uma das principais lutas do disléxico é vencer a imagem de incapacidade reproduzida pela dificuldade de leitura e escrita. Boa escrita e leitura estão diretamente associadas à inteligência e é improvável que o mundo, em geral despreparado para lidar com dificuldades de aprendizagem, olhe para alguém que lê e escreve mal e considere a possibilidade desse indivíduo ser talentoso.

Briana, uma disléxica que se tornou uma talentosa escritora, relata sua experiência:

Embora minhas notas não sejam más, tenho a sensação de que - se as notas de fato refletem a verdade - elas indicam um nível de mediocridade inadequado à minha aptidão intelectual e diligência... Estou pedindo um semestre a mais para completar as disciplinas de uma forma condizente com minha aptidão intelectual e na qualidade de aluna séria ( SHAYWITZ, 2006, p.124).

Eva não consegue ter boas notas:

Eva, de onze anos, é uma aluna brilhante e esforçada. Na aula, é cheia de entusiasmo e de ideias. Estuda bastante e leva suas atividades muito a sério. Seus amigos sempre se impressionam com o jeito que ela fala sobre ciências e história. Mas, quando se trata de fazer provas, Eva nunca vai muito bem. Ela tem sorte de tirar 'B' e geralmente tira ' $C$ '. É muito competitiva com os colegas de classe e constantemente se preocupa com seu boletim. Sua mãe tenta dar pouca importância às notas, embora sempre comemore quando Eva tira um 'B' com um jantar especial ou um cinema. Mas a garota está desolada porque não consegue tirar um ' $A$ ' mesmo nas matérias que mais ama (FRANK, 2003, p.29).

O sujeito capaz ("eu posso") de Ricoeur (2006) desdobra-se no sujeito que pode dizer, fazer, narrar e narrar-se e assumir-se imputável por seus atos. Saldanha afirma que é somente na imputabilidade, a parte final do percurso de sujeito capaz, "quando somos capazes de avaliar e declarar nossas acções e as dos outros como boas ou más, permitidas ou proibidas, que nós somos e nos assumimos como verdadeiramente dignos de estima e respeito" (2006, p.25).

"É, porque o problema da dislexia - hoje eu tenho essa consciência, na época eu não tinha - é você saber que é capaz" (Rubens) 
Esse ciclo da hermenêutica do homem capaz inicia-se com o "poder dizer" - o sujeito falante que reconhece suas capacidades, assim como os heróis trágicos e os personagens homéricos que falam de suas ações incessantemente; um nomear-se enquanto se fazem reconhecer (RICOEUR, 2006, p.109). Quando o sujeito sai do "quê" em direção a "quem", "quem fala", ele está fazendo uma interpretação de si está olhando para sua história, feitos, ações, sucessos e fracasso e essa reflexão do sujeito que fala, ou "autodesignação", acaba por associar-se à alteridade, pois "a palavra pronunciada por uma pessoa é uma palavra dirigida a outra" (p.111). Ao ter a chance de tirar o foco da dislexia, o indivíduo olha para si - reflete sobre sua trajetória, percebe-se como o herói de sua epopeia ou de sua tragédia, reconhecese capaz e sente-se livre para verbalizar sua narrativa, tornando sua fala acessível ao outro, muitas vezes na busca por ajuda ou aceitação.

O segundo momento do sujeito capaz - "eu posso" - está relacionado "à própria ação no sentido limitado do termo, que designa a capacidade de fazer ocorrer acontecimentos no ambiente físico e social do sujeito que age" (RICOEUR, 2006, p.111). "Poder fazer" engloba as declarações nas quais o sujeito se reconhece como sendo a causa e são os mesmos tipos de declarações que personagens homéricos ou os heróis trágicos seriam capazes de formular - retomamos, aqui, a epopeia ou a tragédia de cada um desses indivíduos. Segundo o filósofo, trata-se aqui de adscrição, ou seja, atribuição de um ato intencional a alguém.

\footnotetext{
O termo "adscrição" salienta o caráter específico da atribuição quando esta diz respeito ao vínculo entre a ação e o sujeito, do qual se diz também que ele a possui, que ela é "sua", que ele se "apropria dela". A adscrição visa, no vocabulário que ainda é o da pragmática do discurso, à capacidade de o próprio agente designar a si mesmo como aquele que faz ou que fez. Ela faz ligação do quê e do como ao quem (RICOEUR, 2006, p.113).
}

Adscrição não é imputabilidade. Esta se refere à responsabilidade do agente (veremos logo adiante); aquela diz respeito à "espontaneidade das causas" (p.113), ao sujeito que se nomeia agente da ação por reconhecer que tem ou teve capacidade para agir.

"Aí eu parei de estudar...acho que faltava um ano para terminar o colegial. Aí eu abandonei." - Renata 
(Sobre a frustração na escola) "Aí é um massacre constante. O que vai acontecendo? Você perde o interesse por aquilo. Você fala assim: 'Meu, é uma regra tão idiota que vou burlar todas elas. [...] Aí você começa a burlar e você vai pegando atalho, você faz de tudo. Só que você é sempre uma espécie de fora da lei, entendeu?" - Rubens

"E eu parei de estudar na sexta série do ensino fundamental porque eu decidi que a escola não servia para nada." - Rubens

Apesar de ainda não terem sido diagnosticados naquela época, as decisões de Renata e Rubens foram tomadas devido à pressão pela qual passavam por causa da dislexia. Diante dos obstáculos na vida escolar, ambos tomaram para si a iniciativa de mudar a situação e agiram de acordo com o que sabiam ser capazes de fazer.

O terceiro momento do homem capaz envolve o "poder narrar e narrar-se" e traz a questão da identidade pessoal construída no ato de narrar, que Ricoeur decide definir como identidade narrativa. Essa identidade narrativa envolve uma dialética entre o idem - a identidade imutável, o mesmo - e o ipse - identidade móvel, do si. Para Tourinho, o autor "conseguiu lançar as bases de uma hermenêutica do 'si-mesmo' graças à temática da identidade narrativa" (2014, p.10).

\begin{abstract}
A identidade-idem preenche as características objetivas ou objetivadas do sujeito falante e atuante, enquanto a identidade-ipse se mostra mais adequada para caracterizar um sujeito capaz de se designar a si próprio, como o autor de suas palavras e ações, um sujeito não substancial e não imutável e, no entanto, responsável pelas suas palavras e ações (RICOEUR, 1995, p.128).
\end{abstract}

Como o sujeito disléxico se encaixa nessa dialética? Como qualquer outro sujeito que se propõe a narrar sua experiência. "A experiência vivida pelas pessoas produz mudanças em seu ser. Somos incapazes de falar de identidade sem a ideia de uma história de vida. Nesse sentido, identidade não é apenas mesmidade, mas é também ipseidade" (TOURINHO, 2014, p.11). Esse entrelaçamento da mesmidade e da ipseidade é o que permite a manutenção da identidade ao longo do tempo; o sujeito que narra faz parte da história e os acontecimentos de sua existência podem ser marcados, pontuados e relatados por datas e localizações enquanto a 
experiência toma forma pela narrativa, "daí a necessidade da narrativa para compor uma narrativa de vida capaz de dar coesão às experiências humanas" (2014, p.12).

Finalmente, o último estágio da hermenêutica do si: a imputabilidade. Diferente da adscrição, que envolve atribuição de uma ação a um agente, a imputabilidade dá um passo adiante e refere-se a tornar o sujeito responsável por seus atos. É o "poder assumir as consequências dos seus atos, particularmente aqueles que são considerados um dano, um erro, do qual um outro é considerado vítima" (RICOEUR, 2006, p.119). Exemplos de imputabilidade encontramos nas falas de Rubens, por exemplo, ao assumir que decidiu burlar as regras depois de sentir-se massacrado pelos problemas na escola e ao relatar a decisão de parar de estudar, decisão também tomada por Renata. Sujeitos que tomam decisões, talvez muitas vezes inesperadas e/ou incomuns, mas que assumem sua responsabilidade na situação. Em Ricoeur, o estudo toma um caminho que leva à política (o sujeito de direito) e trata da responsabilidade em um sentido estritamente jurídico - daí a citação acima referir-se a um outro, à vítima. Tomamos a liberdade, aqui, de expandir esse significado de responsabilidade, que, nos casos ouvidos, limita-se a ações cujos resultados negativos atingem, principalmente, os próprios disléxicos e que podem, ou não, causar danos a terceiros. 


\section{CONCLUSÃO}

A dislexia tem um impacto profundo na vida de quem convive com ela. Como não tem cura, acompanha o portador pela vida, marcando todos os momentos que envolvam qualquer atividade relacionada à leitura ou escrita. $\mathrm{O}$ grau pode variar, assim como os sintomas e as maneiras de lidar com ela, tornando a compreensão da narrativa do disléxico ainda mais interessante e desafiadora. Buscamos compreender como se dá a construção da identidade desse sujeito que trava uma batalha diária com algo que, para muitos, acontece tão naturalmente que mal se dão conta de sua importância: a habilidade de ler e escrever sem preocupação.

\footnotetext{
Quando criança, eu era chamado de burro. Era chamado de preguiçoso. $\mathrm{E}$ isso apenas por alguns dos meus professores. Imaginem os nomes que as crianças no pátio da escola acrescentavam à lista. Mesmo agora, que sou adulto, ainda não leio muito bem. Minha letra é abominável e tenho dificuldade em lembrar desde nomes e datas a percursos e a grafia de algumas palavras. Ainda assim, hoje sou psicólogo, autor, professor de faculdade, marido, pai. Não, não sou burro ou preguiçoso. Tenho dislexia (FRANK, 2003, p.xi)
}

Iniciamos este trabalho buscando dar uma visão do caminho percorrido no entendimento da dislexia, desde a era vitoriana até os dias atuais, quando a tecnologia se torna uma grande aliada dos disléxicos, permitindo, por exemplo, o uso de uma fonte especial que auxilia e facilita o árduo processo de leitura. Esse capítulo aborda também o papel da escola e a importância de um posicionamento efetivo quanto à inclusão e apoio do aluno disléxico. Por fim, a globalização, tema inevitável, aparece como uma das justificativas para a urgência na compreensão da dislexia em todos os seus aspetos, já que estamos inseridos em um mundo conectado e que exige fluência na língua inglesa em vários momentos.

O capítulo um apresenta nossa metodologia, baseada nos fundamentos da teoria semiótica de Algirdas Julius Greimas, e descreve o modelo de entrevista utilizado assim como a proposta de desenvolvimento dos capítulos.

O capítulo dois analisa, de forma descomplicada, o conteúdo das entrevistas. Como este trabalho tem como público alvo também o disléxico, o empenho foi em manter uma linguagem clara e acessível, sem termos técnicos que pudessem inibir a leitura daqueles não acostumados à semiótica. As perguntas, previamente 
preparadas, formam um esqueleto a ser percorrido na entrevista, mas não impedem que cada entrevistado discorra, conforme seu desejo, sobre outros assuntos pertinentes ao tema. Essa liberdade gerou um texto fluido, natural e emocionante da trajetória do disléxico, pois toca em sua vida escolar, familiar e profissional; um esqueleto em comum que acabou por gerar narrativas muito similares em alguns aspectos, mas que tomaram caminhos distintos na sua construção. Aqui também levantamos os temas que estruturaram tais narrativas, assim como as figuras de linguagem e as oposições semânticas, ou seja, as oposições de ideias que permearam a fala dos entrevistados e, finalmente, as figuras de retórica que ajudaram a dar vida à cada história narrada.

O capítulo três trata da semiótica das paixões; analisa as modalidades querer, crer, dever, saber, poder, fazer e ser - e suas modalizações - quer-fazer; poder-ser; saber-ser, etc. - que acabam por gerar efeitos na narrativa, sendo muitos desses efeitos o que chamamos de paixões. Percorremos o ressentimento, a vergonha, a culpa, a obstinação, a teimosia e o desespero e traçamos como cada um dos sujeitos chega à paixão mais explícita em sua narrativa.

O capítulo quatro convida para algumas considerações sobre como auxiliar o disléxico em sala de aula. Sabemos ser impossível tratar de metodologias de forma tão sucinta; no entanto, sentimos ser relevante um breve levantamento das principais acomodações que podem ser consideradas por educadores, já que são um instrumento imprescindível para uma inclusão eficaz do disléxico no ambiente escolar.

No capítulo cinco, debruçamo-nos na questão dos estereótipos e retomamos a questão da responsabilidade de escolas e educadores quanto a uma compreensão do que estereótipos (e possíveis estigmas) podem causar no viver e, como consequência, na identidade do disléxico. É na prática do ensino que muitos dos estereótipos podem ser reforçados, abrindo oportunidades para preconceito e exclusão.

Finalmente, no capítulo seis, tendo como base Ricoeur e seu estudo intitulado "Percurso do Reconhecimento" (2006), analisamos como se desenvolve o percurso de reconhecimento de si do disléxico. Utilizamos a proposta do autor, que envolve quatro etapas do homem capaz no caminho do reconhecimento de si: poder dizer, poder narrar/poder narrar-se e o princípio da imputabilidade. 
Quem é, então, o nosso sujeito? Uma das perguntas de nossa entrevista era: "Como você definiria ser disléxico?" e as respostas foram:

"Eu defino que eu tenho uma dificuldade de interpretação, uma dificuldade de entender, leitura, eu detesto leitura, eu odeio livro [...]" Sabrina

"Eu diria que é uma vida normal, você só vai ter um pouco de dificuldade, mas você vai superar as dificuldades [...]" Marcelo

"Eu me sinto uma pessoa normal. Sei das minhas habilidades e desabilidades" Renata

"É uma experiência sofrida. Hoje, com o conhecimento do que é dislexia, eu acho que é um dom, sabe? Ela tem seus lados positivos e negativos, como tudo na vida [...]" Ivana

"[...] é como se você vivesse em um mundo onde todo mundo se comunica através da música e você não conseguisse aprender a música. [...] Você é um quadrado tentando se encaixar num círculo" (Rubens)

"Eu diria que é uma vida normal, você só vai ter um pouco de dificuldade, mas você vai superar as dificuldades, vai conseguir [...]" Tiago

Primeiramente, precisamos ressaltar que a separação entre "ser disléxico" e "ser disléxico aluno de língua inglesa" não é uma separação que possa ser feita sem que se acarrete em prejuízo. É como uma cirurgia de separação de irmãos siameses: as vidas são salvas, mas um lado sempre perderá uma parte de si. Por isso, é necessário que entendamos que tratamos, aqui, de um sujeito disléxico e sua experiência com a língua inglesa. Tendo isso em mente, percebemos que a visão de si como disléxico estende-se à experiência de cada um com o idioma inglês.

Sabrina é a única que não se define pelo uso de qualidades - só aponta seus defeitos (apesar de afirmar mais à frente que sente-se menos frustrada hoje em dia). Sua relação com a língua inglesa passa pelo mesmo caminho - é a única que não conseguiu passar por seus traumas e encarar a tentativa de aprender o idioma. Levanta a possibilidade, mas sofre com ela. Marcelo conseguiu vencer os vários obstáculos na vida escolar e considera-se uma pessoa normal - repete a narrativa quando trata de seu aprendizado de inglês hoje. Encara com normalidade e sente-se mais relaxado e tranquilo com o idioma. 
Renata tem muito claro que há coisas que consegue e coisas que não consegue fazer - e inglês é uma delas. Enquanto fala dessas "habilidades e desabilidades" na vida, parece aceitar bem. Não saber inglês é uma questão ainda não resolvida.

Ivana, como Renata, olha para a dislexia como algo que traz coisas positivas e negativas à sua vida. A frustração na escola estende-se ao inglês, mas considera este um contratempo leve em relação ao contexto de sua vida. "Nem todo mundo é igual".

Rubens não se encaixa - nem no inglês. Para aprender o idioma, tentou várias alternativas e nunca se encontrou. Ele se conhece, sabe de suas habilidades, mas se sente fora do padrão e do que é considerado normal.

Tiago não comenta sobre sua vida na escola, mas, definitivamente, o que sente como disléxico reflete em sua experiência com a língua inglesa. Sua trajetória é de superação de dificuldades, mesmo que devagar. Inglês não é simples, mas ele enfrenta o desafio.

Acreditamos ser necessário retomarmos, nesse momento, a problemática relativa à obrigatoriedade da língua inglesa e o peso que isso pode trazer ao disléxico. Estudar inglês é algo que terá que ser enfrentado em algum momento. A vida escolar já é permeada de dificuldades, frustrações e lutas e partir para o desafio do segundo idioma é uma luta a mais. Como fica claro em nossas entrevistas, a experiência com a língua inglesa, para quem tem a língua portuguesa como língua materna, nunca é fácil; pode ser mais fácil para uns e mais árdua para outros, mas é um contexto que pode ser emocionalmente exaustivo. Esperamos que nossa pesquisa traga um olhar renovador para esse contexto, um olhar que tenta compreender a partir da experiência e da vivência do outro. Também é nosso desejo que as questões aqui levantadas possam abrir outras discussões a respeito do ensinar e do aprender e do que significa incluir e respeitar as individualidades. Deixamos um trecho da Declaração de Salamanca sobre Princípios, Políticas e Práticas na Área das Necessidades Educativas Especiais ${ }^{30}$ :

\footnotetext{
${ }^{30} \mathrm{http}: / /$ portal.mec.gov.br/seesp/arquivos/pdf/salamanca.pdf
} 
- toda criança tem direito fundamental à educação, e deve ser dada a oportunidade de atingir e manter o nível adequado de aprendizagem,

- toda criança possui características, interesses, habilidades e necessidades de aprendizagem que são únicas,

- sistemas educacionais deveriam ser designados e programas educacionais deveriam ser implementados no sentido de levar em conta a vasta diversidade de tais características e necessidades,

- aqueles com necessidades educacionais especiais devem ter acesso à escola regular, que deveria acomodá-los dentro de uma Pedagogia centrada na criança, capaz de satisfazer a tais necessidades.

- escolas regulares que possuam tal orientação inclusiva constituem os meios mais eficazes de combater atitudes discriminatórias criando-se comunidades acolhedoras, construindo uma sociedade inclusiva e alcançando educação para todos; além disso, tais escolas proveem uma educação efetiva à maioria das crianças e aprimoram a eficiência e, em última estância, o custo da eficácia de todo o sistema educacional. 


\section{REFERÊNCIAS BIBLIOGRÁFICAS}

Associação Brasileira de Dislexia. Disponível em: <http://www.dislexia.org.br>. Acesso em: 15 nov. 2015.

ALVES, L.M.; MOUSINHO, R.; CAPELLINI, S.A. (orgs) Dislexia. Novos temas, novas perspectivas. Rio de Janeiro: Wak Editora, 2011.

BACCEGA, M.A. Os estereótipos e as diversidades. Comunicação e Educação Revista do Departamento de Comunicações e Artes da ECA/USP. São Paulo, n.13, 1998. Disponível em: http://www.revistas.usp.br/comueduc/article/view/36820 Acesso em 12 jan 2016.

BARROS, D. L. P. DE. Paixões e apaixonados: exame semiótico de alguns percursos. Cruzeiro Semiótico, n. 11-12, p. 60-73, 1990.

BARROS, D. L. P. DE. Sintaxe narrativa. In: OLIVEIRA, A. C. DE; LANDWSKI, E. (Eds.). . Do inteligível ao Sensível em torno da obra de Algirdas Julien Greimas. São Paulo: Educ, 1995. p. 81-97.

BARROS, D. L. P. DE. Teoria Semiótica do Texto. 5ed. São Paulo: Ática, 2011.

Bright Solutions for Dyslexia. Disponível em: http://www.dysadd.com/resources/General/AccommodationsHandout.pdf Acesso em: 20 out, 2016.

Conceito.de Disponível em: www.conceito.de/reconhecimento Acesso em: 20 ago 2016.

CALBUCCI, E. Modalidade, paixão e aspecto. Estudos Semióticos, v.5, n.2, p.7078, 2009.

CORÁ, E.J.; NASCIMENTO, C.R. Reconhecimento em Paul Ricoeur: da identificação ao reconhecimento mútuo. Revista de Ciências Humanas, v.45, n.2, p.407-423, out/2011.

COSTA, C.F.C.D. As emoções morais: a vergonha, a culpa e as bases motivacionais do ser humano. Dissertação de Mestrado. Universidade de Lisboa. Faculdade de Psicologia e de Ciências da Educação. 2008.

CROMBIE, M. Foreign Language Learning and Dyslexia. Dyslexia Yearbook, 1999. Disponível em http://www.languageswithoutlimits.co.uk/resources/Dxa1.pdf Acessado em: 27 out. $2017^{31}$

CROMBIE, M; SCHNEIDER, E. Dyslexia and Foreign Language Learning. David Fulton Publishers: New York, 2003.

\footnotetext{
${ }^{31}$ Adaptação de um artigo da própria autora entitulado "Bad Language or Good"
} 
DE CAUX, L.P.; VALENTE, J.L. O que é a teoria do reconhecimento? Polos de Cidadania, Minas $\quad$ Gerais, $2010 . \quad$ Dispoível em http://polosdecidadania.com.br/Biblioteca Acessado em: 15 jan. 2016

Dicionário Infopédia da Língua Portuguesa com Acordo Ortográfico. Porto Editora, 2003-2016. Disponível em: https://www.infopedia.pt/dicionarios/linguaportuguesa/reconhecimento. Acesso em: 20 ago 2016.

Declaração de Salamanca. Disponível em: http://portal.mec.gov.br/seesp/arquivos/pdf/salamanca.pdf Acesso em: 20 jul. 2015.

DROIT, R.P. A epopéia de um sentido. Disponível em: http://www1.folha.uol.com.br/fsp/mais/fs2902200407.htm Acesso em: 20 fev. 2016

Estudo da Dislexia. Disponível em http://melofreud.blogspot.com.br/2009/11/depoimento-de-uma-dislexica.html Acesso em: 20 jul. 2015

FIORIN, J.L. Algumas considerações sobre o medo e a vergonha. Cruzeiro Semiótico. n.16. p.55-63, 1992.

FIORIN, J. L. A noção de texto na semiótica. Organon, v.9, n.23, p. 165-176, 1995.

FIORIN, J. L. Elementos da Análise de Discurso. 8. ed. São Paulo: Contexto, 2000.

FIORIN, J.L. Paixões, emoções e sentimentos. Caderno de Semiótica Aplicada, v.5, n.2, p.1-14, dez/2007.

n.1, p.9-22, 2007.

Semiótica das paixões: o ressentimento. São Paulo: Alfa, v.51.

FIORIN, J. L. As Astúcias da Enunciação - as categorias de pessoa, espaço e tempo. 2. ed. São Paulo: Editora Ática, 2010.

FIORIN, J. L. Enunciação (2) - A categoria da pessoa. Disponível em: <http://youtube.com>. Acesso em: 10 jan. 2016.

FONTANILLE, J. Semiótica do discurso. 2 ed. São Paulo: Contexto, 2012.

FRANK, R. A vida secreta da criança com dislexia. São Paulo: M.Books do Brasil Editora Ltda., 2003.

GOFFMAN, E. Estigma - notas sobre a manipulação da identidade deteriorada. 4 ed. Rio de Janeiro: LTC, 2013.

GOMES, W. B. A Entrevista Fenomenológica e o Estudo da Experiência Consciente. Psicologia USP, v.8, n.2, p. 305-336, 1997. 
GREIMAS, J.A.; FONTANILLE, J. Semiótica das paixões. São Paulo: Ática, 1993.

HARKOT-DE-LA-TAILLE, E. Ensaio semiótico sobre a vergonha. Tese de Doutoramento. Universidade de São Paulo, 1996.

HARKOT-DE-LA-TAILLE, E. Sentir, saber, tornar-se: estudo semiótico do percurso entre o sensório e a identidade narrativa. Tese de livre docência. Universidade de São Paulo: 2013.

HOUAISS, A.; VILLAR, M. DE S.; FRANCO, F. M. DE M. Dicionário Houaiss da Língua Portuguesa. Rio de Janeiro: Objetiva, 2009.

JAHN, F. 0 fator mascarado. Disponível em: $<$ www.revistaeducacao.com.br/textos/148/artigo234627-1.asp >. Acesso em: 15 dez. 2015.

KUMARAVADIVELU, B. (Re)Visioning Language Teacher Education in Language Teacher Education for a Global Society: a modular model for knowing, analysing, recognizing, doing, and seeing. New York and Oxon: Routledge, 2012.

LARA, G.M.P.; MATTE, A.C.F. Um panorama da semiótica greimasiana. Alfa Revista de Linguística. v.53, n.2, 2009. Disponível em: http://seer.fclar.unesp.br/alfa/article/view/2119 Acesso em: 24 fev. 2016.

LARA, G.M.P.; MATTE, A.C.F. Examinando emoção e paixão. In: MARCHEZAN, R,C; CORTINA, A.; BAQUIÃO, R.C. (orgs) A Abordagem dos Afetos da Semiótica. São Carlos: Pedro \& João Editores, 2011.

LIPPMANN, W. Opinião pública. 2. ed. Petrópolis, RJ: Vozes, 2010.

LAWRENZ, J. Hegej, recognition and rights: 'Anerkennug' as a gridline of the philosophy of rights. Cosmos and History: The journal of natural and social philosophy. v.3, p.153-169, 2007

LOURENCETI, M.D.; SANTOS, L.C.A,; PADULA, N.A.M.R. Dislexia e comorbidades na infância e na adolescência. In: ALVES, L.M.; MOUSINHO, R.; CAPELLINI, S.A. (orgs) Dislexia. Novos temas, novas perspectivas. Rio de Janeiro: Wak Editora, p.306-307, 2011.

LUKE, A., FREEBODY, P. Shaping the social practices of reading in Monte Mor, W. Crítica e letramentos críticos: reflexões preliminares In ROCHA, C. H. e MACIEL, F. R. (orgs) Língua Estrangeira e Formação Cidadã: por entre discursos e práticas. Campinas: Ed. Pontes, 2013.

MARTINS, S.P. Déficit de atenção e dislexia na escola. Disponível em: http://www.tdah.org.br/br/artigos/textos/item/374-d\%C3\%A9ficit-de-

aten\%C3\%A7\%C3\%A3o-e-dislexia-na-escola.html Acesso em: 17 jul. 2016.

MELLO, L.C.M.F. A vergonha. In: MARCHEZAN, R,C; CORTINA, A.; BAQUIÃO, 
R.C. (orgs) A Abordagem dos Afetos da Semiótica. São Carlos: Pedro \& João Editores, 2011.

MIYASHIRO, S,G.; SCHILLING, F. Como incluir? O debate sobre o preconceito e o estigma na atualidade. Educação e Pesquisa, São Paulo, v.34, n.2, p.243-254, maio/ago $2008 .^{32}$

MONTE MOR, W. Crítica e letramentos críticos: reflexões preliminares. In ROCHA, C. H. e MACIEL, F. R. (orgs) Língua Estrangeira e Formação Cidadã: por entre discursos e práticas. Campinas: Ed. Pontes, 2013.

GOERGEN, P. Educação e valores no mundo contemporâneo. Educ. Soc., Campinas, v.26, n.92, p.983-1011, out, 2005. Especial.

NORTON, B.,TOOHEY, K. Critical pedagogies and language learning. United Kingdom: Cambridge University Press, 2004.

RABELO, C. Semiótica Discursiva parte 01. Disponível em: <https://www.youtube.com/watch?v=X3No-i1wzRg>. Acesso em: 17 fev. 2016.

RICOEUR, P. Percurso do reconhecimento. São Paulo: Loyola, 2006.

Autobiografia Intelectual. Lisboa: Instituto Piaget, 1995.

SALDANHA, F.A.M. Do sujeito capaz ao sujeito de direito: um percurso pela filosofia de Paul Ricoeur. Tese de Doutoramento em Filosofia. Coimbra: Faculdade de Letras, Universidade de Coimbra, 2009.

SAVIANI, D. Pedagogia Histórico-Crítica. Campinas, SP: Editora Autores Associados Ltda., 2013

SHAYWITZ, S. Entendendo a dislexia - um novo e completo programa para todos os níveis de problemas de leitura. Porto Alegre: Artmed, 2006.

SILVA, F. M. Modalização: teoria e aplicação. Revista Prolíngua, v.2, n.2, p.48-56, 2009.

SUARÉZ-OROZCO, M. , QIN-HILLIARD, D. Globalization: culture and education in the new millenium. London: University of California Press, 2004.

TOURINHO, L.S. Sobre a questão do sujeito em Paul Ricoeur. Theoria - Revista Eletrônica de Filosofia, v.vi, n.15, p.1-16, 2014. Disponível em: http://www.theoria.com.br/?p=677 Acesso em: 20 set 2016.

${ }^{32}$ Artigo organizado a partir das reflexões da dissertação de mestrado de Sandra Galdino Miyashiro, Filhos de presidiários: um estudo sobre estigma, orientada por Flávia Schilling. 


\title{
9. ANEXOS
}

\section{ANEXO A: OS DIREITOS DOS DISLÉXICOS}

Simoni Lopes de Sousa, mãe de disléxico e advogada especialista em Direito Educacional, contribui para o blog Dislexclub ${ }^{33}$ com artigos sobre legislação e direito dos portadores de dislexia. Ela afirma que, antes de qualquer projeto de lei, a Constituição Federal é a ferramenta mais eficaz para a garantia dos direitos desse grupo de indivíduos ${ }^{34}$. Como o acesso à educação é um direito fundamental e uma garantia constitucional que fazem parte das cláusulas pétreas, é através da Constituição que entenderemos como defender os direitos não só de disléxicos, mas de todo aluno portador de deficiência e/ou que precisa de apoio em sala de aula.

\begin{abstract}
A educação, direito de todos e dever do Estado e da família, será promovida e incentivada com a colaboração da sociedade, visando ao pleno desenvolvimento da pessoa, seu preparo para o exercício da cidadania e sua qualificação para o trabalho (Artigo 205 da CF) $)^{35}$
\end{abstract}

A autora também cita o inciso I do Artigo 206, sobre os princípios que devem reger o ensino, que ordena a igualdade de condições para que o aluno tenha acesso e possa permanecer na escola.

Em outro artigo, intitulado "Relação entre família e escola"36, Simoni Lopes de Sousa adverte as famílias para que documentem toda a comunicação com a escola (protocolos de entrega de laudo, boletins, comunicados, atas de reuniões, etc) para que a instituição de ensino não tenha como negar que tenha conhecimento do caso. Ela também oferece um modelo de uma carta de tutela que informa o laudo e dados do médico responsável e que deve ser entregue à escola ${ }^{37}$. Em resumo:

\footnotetext{
${ }^{33}$ www.dislexclub.com

${ }^{34}$ www.dislexclub.com/legislacao-que-ampara-o-aluno-dislexico

${ }^{35}$ www.senado.gov.br/atividade/const/constituição-federal.asp

${ }^{36}$ www.dislexclub.com/relacao-entre-familia-e-escola

${ }^{37}$ www.dislexclub.com/documento-para-tutela-do-aluno-dislexico
} 
1) A matrícula de um aluno Disléxico (ou NEE) jamais pode ser negada, e se isso acontecer, solicite a negativa/justificativa POR ESCRITO;

2) No ato da matrícula, os pais deverão informar e fornecer à instituição de ensino cópias de diagnóstico/laudos médicos, psicológicos, fonoaudiólogos e demais profissionais que atuam multidisciplinarmente com o aluno, para comprovar o direito de atendimento especial;

3) Após o início do ano letivo, a instituição de ensino deverá elaborar juntamente com a família um plano de desenvolvimento individual (PDI) para atendimento/adaptação curricular do aluno [...] (Relação entre família e escola)

\section{Enem e concursos públicos}

Segundo Simoni Lopes de Sousa, as melhores disposições inclusivas no pais são, hoje, as que fazem parte do edital do ENEM. "[...] além de contemplar de maneira eficaz a Legislação Inclusiva vigente, o edital do ENEM/INEP respeita de maneira singular a condição do candidato desde a inscrição até a correção final das provas"38. O aluno disléxico pode requisitar o atendimento diferenciado no ato da inscrição desde que possua um laudo diagnóstico (declarações com Hipóteses Diagnósticas não serão aceitas) que deve conter a qualificação do paciente, diagnóstico conclusivo, código do CID ou CIF e descrição da condição do paciente.

Em concursos públicos, Simoni esclarece que disléxicos não podem concorrer a cotas destinadas a deficientes físicos, mentais ou intelectuais já que dislexia e TDAH são considerados Transtornos/Distúrbios Neurológicos ${ }^{39}$. Porém, como portadores de dislexia têm prerrogativas legais de atendimento, mesmo nao havendo uma legislação específica para o distúrbio, eles têm a seu lado um série de leis que auxiliam na inclusão do disléxico, tais como: a Declaração de Salamanca, Leis de Diretrizes e Bases da Educação Nacional Brasileira, Diretrizes da Política Nacional de Educação Especial na Perspectiva da Educação Inclusiva, alguns decretos e a Constituição, já citada anteriormente. Alguns dos atendimentos específicos que podem ser solicitados pelos disléxicos incluem: tempo extra para realização das provas, correção diferenciada da prova escrita e auxílio de ledor e transcritor.

** Todas essas informações e muito mais estão acessíveis nas URLs citadas.

${ }^{38}$ www.dislexclub.com/direitos-dos-dislexicos-no-enem
${ }^{39}$ www.dislexclub.com/direitos-dos-dislexicos-em-concursos-publicos 


\section{ANEXO B: TRANSCRIÇÃO - IVANA}

Entrevistadora Claudia: Ótimo. Então, só para a gente começar, Ivana... Ivana, não é? Já tenho o teu nome, me fala a sua profissão e a sua idade.

Entrevistada Ivana: Eu sou Ivana Cristina de Arruda, sou Fonoaudióloga e estou com 87 anos. dislexia?

Entrevistadora Claudia: E então vamos falar um pouco da dislexia. Como é que você descobriu a sua

Entrevistada Ivana: Então, eu sempre desconfiei que tinha alguma coisa, porque tinha dificuldades na escola, era muito lenta pra fazer cópia. Me recordo que as meninas saíam para o intervalo e eu ficava ainda copiando da lousa.

Entrevistadora Claudia: Certo.

Entrevistada Ivana: Muita dificuldade na ortografia, mesmo depois de adulta, mesmo gostando de ler, porque eu sou uma disléxica que gosta de livros. Compro livros, então assim... Só que eu lia por uma determinação, eu sou muito determinada, então vamos supor assim, eu me propunha todas as férias, por exemplo, eu tinha que fazer um trabalho artesanal e ler um livro. E se não fosse férias de Julho, fosse todo mês eu me empenhava para fazer pelo menos alguma coisa manual, algo que é também uma dificuldade, então, eu mesmo. Só que eu demorava uma vida para ler esses livros, você entendeu? O que as pessoas fazem com rapidez, as pessoas... uma certa lentidão, isso me chamava bastante atenção, mas eu me propunha em fazer. Depois quando foi para a decisão da faculdade, eu pensei uma coisa, eu não sei... Mesmo indo de encontro com a dificuldade para procurar solucionar, procurar entender melhor. Eu tinha muitas facilidades em outras áreas, eu sempre achei que em algumas coisas... Vamos deixar a modéstia de lado, "tá"? Falar de modéstia vai parecer presunção. Tenho em algumas coisas muita facilidade.

Entrevistadora Claudia: Certo.

Entrevistada Ivana: Estar acima, vai chegar antes dos outros. E em algumas coisas, que no caso a leitura, não acompanhava os outros. E outra coisa assim também que chamava atenção é a desorientação espacial e a desorientação temporal. Então, eu não consegui gravar caminho, não consegui... Então, por um lado você se sente assim estúpida, entendeu?

Entrevistadora Claudia: Sim.

Entrevistada Ivana: Burra mesmo, você tinha aquela coisa... Você não aprende, não consegue. E por outro lado você fala: "poxa, mas eu sou tão inteligente em outras coisas.

Entrevistadora Claudia: O que acontece, não é?

Entrevistada Ivana: É um contraste que é difícil, é conflitante que às vezes você faz alguma coisa como os outros e essa coisa "ah nossa, como você é inteligente, como você é rápida, como você pega rápido". Eu falava assim "espere para ver um pouquinho". Aí investi no <ininteligível - 0:03:00.9>. Daqui um pouquinho você vai que eu não sou tão inteligente assim. <Ininteligível - 0:03:06.2> baixa a autoestima de achar que as pessoas de repente iriam descobrir que não era tudo aquilo que elas achavam.

Entrevistadora Claudia: Certo.

Entrevistada Ivana: Então foi bom porque administrar esses dois extremos faz com que você mantenha também um certo grau de humildade, também reconheça os potenciais das pessoas, que cada um é de um jeito, que cada um tem seu talento. Enfim, isso para mim eu acho foi uma coisa positiva. Com os idiomas eu não tive dificuldade. Igual eu falei para você, quando criança eu aprendi inglês, ia muito bem em inglês, principalmente na parte oral, tinha dificuldade auditiva.

Entrevistadora Claudia: Uhum. Certo.

Entrevistada Ivana: Mas não foi para frente o meu inglês, acho que foi para frente outros idiomas latinos, que tive a oportunidade de viver para isso. Eu acho que quando você convive, quando você é mais exposta ao idioma fica muito mais fácil.

Entrevistadora Claudia: Você diz então que a oralidade era mais fácil, não é? A parte oral. Existia alguma coisa no inglês ali, com a qual você sentia um pouco mais ou frustrada ou com dificuldade? Mesmo gostando e achando que até que estava indo?

Entrevistada Ivana: Sim. Quando as palavras eram muito semelhantes, que precisava ter a questão auditiva quando criança, hoje eu tenho mais um mais de [cinco ouvidos, a velha]. Mas, por exemplo, os garfos eram difíceis de saber quando era uma palavra que o "o" era mais acentuado, o "t", entendeu? Assim, um o "t" mais rápido o outro um "t" mais demorado. Então não conseguia perceber muito essas diferenças. Isso aconteceu também com o italiano, o italiano tem as <ininteligível - 0:04:55.3>, não é? Então as <ininteligível 0:04:57.9>, tem que alongar esse "l", escrever com dois "l", não é? As palavras que se escrevem com dois "m". Enfim, foi uma coisa que, quando eu aprendi, tive uma certa dificuldade até para compreender esse som mais longo. Hoje, para mim, como fonoaudióloga está tranquilo. Então, assim, essa coisa de você procurar... Quanto mais informação você tem, pelo menos para mim como disléxica, uma coisa que me facilita é ter mais informações, porque aí eu tenho mais possibilidade de conexões. Foi estratégia que eu acho que eu uso desde pequena e hoje eu consigo compreender melhor porque é que eu fui buscar esse tipo de estratégia.

Entrevistadora Claudia: Entendi, entendi.

Entrevistada Ivana: E na época não existia nem o conselho de dislexia, sabe? Existia o aluno inteligente e o aluno burro, eu estava no segundo grupo, não é? E aí, eu estava lutando contra isso, para entrar no primeiro grupo, não é?

Entrevistadora Claudia: Certo.

Entrevistada Ivana: E aquela coisa você fica lá... não repete de ano. Fica sempre... Certo que eu repeti um ano, mas por indisciplina.

Entrevistadora Claudia: Não pode nem culpar a dislexia. 
Entrevistada Ivana: Não é? Mas assim, você consegue recuperar bem as matérias, não repete de ano, não é a primeira da classe, mas também não é a única, sempre fui uma pessoa que passava desapercebida. Mas eu sabia que podia mais, que podia ter notas melhores. Por exemplo, a minha professora de ciências na quarta série adorava. Ela dizia assim "nossa, você é a melhor aluna que eu já tive na minha vida, como você é boa em ciências". Aí você vai olhar a média de ciências, não passa de $6,5,7$. Porque era uma época que qualquer erro ortográfico diminuía a sua nota. Então apesar dela achar que eu era aluna 10, eu nunca tive um 10 em ciências. Então isso era altamente frustrante.

Entrevistadora Claudia: Certo

Entrevistada Ivana: E assim, sofri com aquela coisa, aí depois que fiz fono, você vai driblando, "tá", "tá", "tá". Eu fui fazer avaliação para dislexia recentemente.

Entrevistadora Claudia: Ah, formalmente. Entendi.

Entrevistada Ivana: Formalmente, eu fiz um laudo. Aí fui na DP, conversei com a Ângela, foi sofrido porque eu fugia. Leitura - escrita. Na faculdade eu nunca tirei um paciente... Eu não queria os pacientes de leitura - escrita, eu os pacientes de fala, os pacientes de outras patologias por trabalhar com <ininteligível 0:07:35.2>. Daí quando eu fui fazer... Porque também a vida faz, não é? Aí quando eu fui fazer o meu estágio na clínica, era por sorteio e o meu paciente era a leitura - escrita. Daí foi. Aí depois de muito lutar, eu resolvi que não, que eu precisava trabalhar com leitura escrita porque eu entendia esses pacientes. Foi uma coisa muito legal, assim, para minha vida.

Entrevistadora Claudia: Interessante, muito legal. Então voltando um pouquinho lá para o inglês, você se lembra das aulas, assim, como você se sentia?

Entrevistada Ivana: Era tranquilo, eu era boa no inglês. Minha média era 9,6.

Entrevistadora Claudia: Certo. Aham.

Entrevistada Ivana: E 13 anos de idade. Aí entrou a adolescência, meu professor de inglês era muito ruim. E muito ruim e muito... A escola era muito ruim, era escola pública. Foi uma época que mudei de cidade, a gente foi morar numa escola... E o quê que aconteceu. Esse professor pedia doces, bombons para os alunos, usava a turma à base de chocolate.

Entrevistadora Claudia: Que lindo.

Entrevistada Ivana: Muito lindo. Teacher era o nome dele. E era aquela coisa "the book is on the table", umas coisas assim que não estimulava ninguém e era terrível, só matava aula no inglês, nessa época, foi aí que eu repeti de ano. Eu repeti nas matérias mais estúpidas que você possa imaginar. Como eu era muito indisciplinada, brigava muito com os professores, por conta dessa escola bagunçada, eu repeti em desenho e inglês.

Entrevistadora Claudia: Olha, que coisa.

Entrevistada Ivana: Então, eles faziam [provas] bem chatas em alguma coisa, porque se me deixasse, por exemplo, em geografia chegava na época das férias eu estudava, eu tirava nota.

Entrevistadora Claudia: Certo, certo. Você não chegou a fazer inglês fora da escola?

Entrevistada Ivana: Fiz o FISK e fiz depois, de adulta, aí eu quis estudar porque já tinha aprendido o italiano, já aprendido o espanhol. O espanhol foi maravilhoso. O espanhol, a correspondência da grafia, fonema é exata. Não tem dois "s", "ç", não tem como se confundir. Só que "sc" som de <ininteligível - 0:10:10.8> "c" e não tem erro. É muito semelhante à regra do português. Então daí eu quis fazer inglês, eu fiz... Não tive tanta dificuldade, mas eu sinto uma dificuldade no inglês quando é assim... Por exemplo, eu não memorizo uma música em inglês.

Entrevistadora Claudia: Sim, é a segunda ou terceira pessoa que me fala isso.

Entrevistada Ivana: É. Por exemplo, eu fui para o inglês porque eu gosto de cantar. E eu gostaria de cantar em inglês, mas é raro eu conseguir cantar em inglês, porque eu preciso de muitos elementos para eu poder memorizar aquela letra, entendeu? Eu tenho que ir ao Youtube, ver escrito, ouvir várias vezes. Então eu preciso de vários elementos. Como eu falei para você, quanto mais elementos eu tenho, mais fácil para mim.

Entrevistadora Claudia: Sim.

Entrevistada Ivana: Então não é uma coisa só que o professor deu, você pega a letra e sai cantando.

Entrevistadora Claudia: Mas como você se sente quando você quer cantar e não consegue?

Entrevistada Ivana: É frustrante, é frustrante. Você se sente igual aquela menina lá do... como é que chama... Aquele programa horroroso... Aquele programa de televisão, Big Brother eu acho, que a menina cantava...

Entrevistadora Claudia: Lembro.

Entrevistada Ivana: Que entrou em bullying, não é?

Entrevistadora Claudia: Lembro.

Entrevistada Ivana: Uma coisa assim. Eu não assisto esse programa, mas ficou...

Entrevistadora Claudia: Isso ficou cômico, não é? Ficou famoso. Exatamente.

Entrevistada Ivana: E eu me sinto igualzinha a ela <ininteligível - 0:11:39.5> se não vou ficar... Aí eu não canto, simplesmente. Em inglês eu canto. A não ser que tenha uma letra, tem umas músicas que eu gosto muito. E eu tenho por escrito, aí eu gosto dela escrita.

Entrevistadora Claudia: Entendi.

Entrevistada Ivana: Preciso da escrita, para poder... E as regras, não é? Eu preciso muito das regras. Quando você vai nas escolas, normalmente, eles "socam" muito a oralidade e não dão as regras. E aí, eu não consigo fazer, uma que não tenho com o que associar por quê que é assim. Parece uma coisa que não é difícil, mas assim... Quanto mais informação eu tenho...

Entrevistadora Claudia: Melhor. 
Entrevistada Ivana: ...para mim é melhor. A origem da palavra... Mesmo no português. Mas é aquela coisa que eu falei para você, porque eu não sinto a diferença? Porque em todos os idiomas para mim é assim. $O$ português é assim também.

Entrevistadora Claudia: Sim. Sim.

Entrevistada Ivana: Entendeu? Então se às vezes eu vou... Eu sou Fonoaudióloga, eu faço todo dia com a <ininteligível - 0:12:44.9> anaminese. Você tem paciente novo. <Ininteligível - 0:12:47.6> foi cesária ou foi parto normal? Ah, foi cesária. Aí eu penso "cesária, é com s ou com z?". Dá aquele nervoso porque o pai está na sua frente, entendeu? Um desespero, me dá um branco na hora. E assim, o que eu faço? Faço um formulariozinho onde eu já escrevo como que é certo.

Entrevistadora Claudia: Certo, já está lá. Estratégia, não é?

Entrevistada Ivana: Estratégia. Tem que se definir nessa vida.

Entrevistadora Claudia: Como que é hoje a sua questão com o inglês? Você gostaria de estudar ou você acha que...

Entrevistada Ivana: Adoraria estudar. A minha frustração é não falar inglês. Por quê? Eu tenho uma neta morando nos Estados Unidos, ela vive em Miami, possivelmente eu vou para lá. Quando eu vou para os Estados Unidos, eu fui só uma vez, eu falo espanhol o tempo todo. Como em Miami, principalmente, todo mundo entende o espanhol. Aí, Cláudia, [fica a sua sombra], você fala: "poxa, poderia estar falando em inglês, mas não sei Inglês". E aí algumas coisas que você arrisca, mas estando lá no meio eu percebo que até a compreensão é melhor. Deu falar "se eu morasse aqui uns 4 ou 5 meses eu iria aprender alguma coisa". Agora se eu fico na escola, eu posso ficar 6 meses na escola de inglês, quando eu saio eu lembro muito pouca coisa.

Entrevistadora Claudia: Não é eficaz.

Entrevistada Ivana: Não consigo memorizar alguns vocábulos, entendeu? Não é eficaz. Ineficaz. Falta alguma coisa, falta praticar em primeiro lugar. Você não tem onde usar o que você conhece, então, aquilo cai. Se o português cai, imagina... e eu estou praticando todo dia e eu não consigo gravar <ininteligível - 0:14:35.6>.

Entrevistadora Claudia: Exatamente.

Entrevistada Ivana: E uma língua que você não usa, não tem nem como, não prático, não faço... Mas eu gostaria, gostaria muito.

Entrevistadora Claudia: Uhum. Que legal. Mas é interessante, não é? É uma experiência muito interessante a que você tem. Como você tem esse jeito muito incisivo, se eu te perguntar assim: defina o que é ser disléxico para você? Na sua experiência.

Entrevistada Ivana: Essa não é uma definição fácil.

Entrevistadora Claudia: Não.

Entrevistada Ivana: É uma experiência sofrida. Hoje, com o conhecimento do que é dislexia, eu acho que a dislexia é um dom, sabe? Ela tem os seus lados positivos e negativos, como tudo na vida, mas que é difícil quando você... Essa compressão, eu sinto não ter encontrado um profissional que compreendesse isso na minha infância.

Entrevistadora Claudia: Sim.

Entrevistada Ivana: Porque hoje eu estou com 58 anos. Então há 50 anos atrás, quando eu tinha 8, eu sofria muito.

Entrevistadora Claudia: Imagino. Imagino.

Entrevistada Ivana: Claudia, eu vou dizer para você, eu aprendi a ler e a escrever sozinha. Então assim, eu amava escrever, amava. Então a frustração, quando você começa a errar, não é? E a ser corrigida, corrigida pelos e-mails, desconta meio ponto cada vez que você erra. Então por que eu amava? Porque eu tinha as minhas primas mais velhas que já estavam na escola. Eu tinha primas de todas as idades, mas eu acompanhava as mais velhas. $E$ as minhas melhores amigas sempre foram 4 ou 5 anos mais velhas do que eu, hoje elas têm 20 anos mais nova. Época da infância era muito assim. E eu era muito...como vou dizer... fingida.

Entrevistadora Claudia: Certo.

Entrevistada Ivana: Meu pai era muito rígido, meu pai era disléxico na minha opinião. Nunca fez o exame, mas tem todo o comportamento, tem toda... já morreu, mas eu lembro de aspectos dele assim, muito semelhantes comigo. E coisas assim, essa desorientação temporal, essa desorientação espacial, a dificuldade de memória de algumas coisas, tem o fator intencional, você é desatenta... Mas eu era uma pessoa tão rígida, que quando eu tinha que me concentrar eu me concentrava tanto. Então não entendia esse negócio de ser desatenta. E mesmo... Assim, eu poderia estudar em praça pública, podia estudar dentro do ônibus, entendeu? Com barulho, com tudo, eu estudava e tirava nota boa. Então assim, é uma desatenta em que sentido? Porque se você consegue um nível de concentração até com todos os desfavorecimentos possíveis, por quê que não funciona, entendeu?

Entrevistadora Claudia: Sim, sim.

Entrevistada Ivana: É uma experiência dolorosa, estranha. É experiência bonita. Com a maturidade, a espiritualidade, tudo isso ajuda você a driblar tudo isso e entender um outro valor das coisas. É como eu digo: dislexia hoje para mim é um dom porque eu trabalho com bastante pacientes disléxicos, ajudo a que eles tenham... Vencer essa baixa autoestima, entender que eles têm um dom diferentes dos outros e que cada um tem o seu. E é ir para frente. Que a vida, isso não importa, nem todo mundo é igual, nem todo mundo precisa saber tudo. Quer dizer, você se cobra muitas vezes coisas que num... Então por exemplo, assim como eu não era boa de inglês, eu nunca fui boa de educação física. A pessoa não tem orientação espacial, a colega quando a bola vem, você bate na bola.

Entrevistadora Claudia: Exatamente. 
Entrevistada Ivana: Ping-pong eu jogo muito bem, xadrez, tudo que é raciocínio, tudo que é carta, baralho, a gente gostava disso em casa, então isso me estimulava. Alguém que gostava. Mas no esporte, no vôlei, essa coisa de cesta, sabe? Queimada, nossa senhora, jogava, mas eu saía como se eu tivesse indo para a guerra, toda roxa.

Entrevistadora Claudia: Ah, meu Deus.

Entrevistada Ivana: Então assim, tem coisas que não são exigidas socialmente. Você não precisa ser uma boa jogadora para ser aceita.

Entrevistadora Claudia: Sim, sim.

Entrevistada Ivana: Mas se você não consegue memorizar algumas coisas, ou se você não consegue ler, isso mexe com a aceitação.

Entrevistadora Claudia: Sim, você na sua profissão, se o pai vê que você não escreveu cesária correto, ("Nossa, eu perco o emprego") ele nunca vai achar que é por uma questão de dislexia. "Meu Deus do céu, a médica da minha filha é burra".

Entrevistada Ivana: Exatamente. A desorientação espacial e temporal, por exemplo. Marcar dois pacientes no mesmo horário ou de você não lembrar que daqui uma semana tem determinado compromisso. Mesmo com a agenda, Claudia, se eu te contar dá medo. Eu cheguei a levantar 6 horas da manhã num dia, acordar meu marido e falar "vamos embora que São Paulo tem curso". E eu de banho tomado, maquiada, já prontinha para ir para São Paulo, e ele disse "mas não era... não tinha... hoje não é dia 17?". "É". "De Julho". Ele disse "Não filha, nós estamos em Junho". Então "tá", então vamos voltar a dormir porque o curso é só no mês que vem.

Entrevistadora Claudia: Gente, que inacreditável. Eu não sabia que chegava a esse... olha para mim é uma surpresa.

Entrevistada Ivana: <Ininteligível - 0:20:38.2> em outros, não é?

Entrevistadora Claudia: Você poderia escrever um livro.

Entrevistada Ivana: Num certo momento isso passa a ser engraçado, divertido. Depois você acaba brincando com a situação, mas tem coisas que comprometem. Meu marido fazia fotografia e a gente marcou um evento para fotografar na praia. Aí eu ligo pra pessoa e digo "estou indo para o hotel, estou chegando". "Chegando onde?". "No hotel, você não está no hotel?". "Eu estou no hotel, mas você vai fazer o quê?". "Mas não é hoje o seu evento?". "Não, foi semana passada, eu estou num hotel, mas em férias". Quer dizer, eu perdeu um trabalho, então, às vezes tem prejuízos. Aí não é engraçado, aí é sofrido...

Entrevistadora Claudia: Sim.

Entrevistada Ivana: ...pagar mico, um dia péssimo, você prejudica outras pessoas, enfim. Então meu grande medo era de causar prejuízo, entendeu? Então assim, o inglês, nesse contexto todo, passa a ser um detalhe bem leve, porque assim, de tantas coisas que eu não consigo e entre tantas coisas que eu consigo, tem o inglês.

Entrevistadora Claudia: Entendi.

Entrevistada Ivana: Que eu gostaria de fazer, mas que tenho dificuldade, mas se eu for exposta, se eu ficar <ininteligível - 0:21:58.4>. Ficamos 1 mês nos Estados Unidos, que eu falava bastante espanhol. E eu estava entendendo muito o inglês, mesmo sem falar, eu consegui compreender bastante. Mas em casa eu estava falando português, então não foi uma exposição assim, como eu gostaria, não é.

Entrevistadora Claudia: Certo. Certo.

Entrevistada Ivana: E é isso. Não sei <ininteligível / vozes sobrepostas - 0:22:25.2>. usar você muito.

Entrevistadora Claudia: Perfeito. Super obrigada. Assim, acho que vai ter coisas muito legais, vou

Entrevistada Ivana: Obrigada.

\section{ANEXO C: TRANSCRIÇÃO - MARCELO}

Entrevistadora Claudia: Então está bom, Marcelo a gente vai retomar a ligação caiu, então para você repetir para mim a primeira pergunta. Para você o que ser disléxico?

Entrevistado Marcelo: Para mim, ser disléxico é como se fosse... não é uma falta de inteligência que a pessoa tem, e sim, uma falta de alguma coisa, de algum mecanismo, de alguma ligação que faz com que a pessoa possa entender igual a uma pessoa comum consegue entender uma matéria, algo, entendeu?

Entrevistadora Claudia: Aham.

Entrevistado Marcelo: E fora no entendimento na leitura também, quando o professor vai falar também. Para mim, sempre foi isso que eu percebi, entendeu? Foi essa dificuldade, que o professor podia falar várias vezes a mesma coisa também, olhando para o professor na cara dele, focando somente no que ele está falando, mas aquilo não entrava, sabe? Faltava realmente alguma coisa.

Entrevistadora Claudia: Sei. Era assim que você se sentia em sala de aula?

Entrevistado Marcelo: Sim.

Entrevistadora Claudia: Certo. Em sala de aula de inglês, em aulas de inglês, como você se sentia?

Entrevistado Marcelo: Bom. A aula de inglês é realmente o maior, meio que trauma assim, para mim, porque eu lembro que eu comecei inglês desde pequeno, a minha mãe é professora de inglês, então, eu tinha como manter o inglês em casa também. Só que com o passar dos anos eu fui fazendo inglês, só que eu não conseguia vontade de jeito nenhum, noção de palavras, decorar muitas de palavras em inglês, saber o quê que 
são exatamente. Para mim sempre foi uma luta. E acabou que um tempo na minha vida que fui parar com 16 anos, fazendo turma de inglês com pessoal de 12 anos. Então isso realmente foi uma frustação, que eu falei: "'pô' eu não consigo avançar". Entendeu? Então meio que começou vim mais tarefas na minha vida, começou vim terceiro ano, final do ensino médio, e acabei meio que largando o inglês de lado. Uma que para minha mente sempre foi complicado. Sempre foi uma pedra no meu sapato, o inglês.

Entrevistadora Claudia: Certo. Você acha que no seu aprendizado, a dislexia teve influência?

Entrevistado Marcelo: Ah, eu acho que sim, porque eu em si, eu tomo remédio <ininteligível 0:02:24.3 > vitamina, e a minha mãe sempre fala que eu sou muito presente na minha vida, ela sempre me bajulou bastante, me ajudou a estudar. Minha mãe sempre desde pequeno estudava comigo, fez resumo, sempre ficava no meu pé. Então, eu sempre ia razoavelmente, bem nas provas, nos testes. Só que a partir do ensino médio, minha mãe começou a meio que deixar estudar sozinho, por conta própria, porque eu realmente precisava aprender.

Entrevistadora Claudia: Sim.

Entrevistado Marcelo: Depois disso, as minhas notas só começando a cair, minha mãe começava a ver que realmente faltava alguma coisa, ela via eu sentado, estudando, mesmo tempo que eu estudava com ela, não fluía. Depois que a gente começou a fazer o tratamento, eu comecei tomar remédio, que é vitamina e comecei também a usar outros mecanismos, e isso nota que para o meu aprendizado foi mudando da água para o vinho.

Entrevistadora Claudia: Certo.

Entrevistado Marcelo: Porque antes "pô" quase impossível, muito difícil, hoje em dia não vou dizer que é fácil, mas bem mais fácil de alcançar.

Entrevistadora Claudia: Certo. Então, de novo, pensando nas suas aulas de inglês, você consegue lembrar situações ou atividades em que você sentiu a influência da dislexia especificamente?

Entrevistado Marcelo: Eu acho que é mais na parte de conversação, acho que era a pior parte para $\operatorname{mim}$.

Entrevistadora Claudia: Certo. Por que você se lembra?

Entrevistado Marcelo: Porque na parte de conversação, eu lembro que... você tem que ter pelo menos ter uma base de cada palavra em inglês. Eu podia aprender... eu lia a mesma palavra, aprendia ela, só que ela nunca...parecia que... não registrava, entendeu?

Entrevistadora Claudia: Certo.

Entrevistado Marcelo: Então, eu nunca consegui ter um vocabulário correto para trazer, para provas eu sabia porque sempre tinha um pouco no texto, que sempre me ajudava a fazer a prova, mas conversação sempre foi o pior, porque sempre faltava alguma coisa, sempre faltou alguma coisa.

Entrevistadora Claudia: Certo. Então nessas situações, se eu te pedisse para me descrever como você se sentia e como você se via como aluno. O que você me diria?

Entrevistado Marcelo: Olha, eu te diria, eu me via como uma criança triste, não é? Eu sempre tive interesse de aprender, sempre gostei de aprender. Para mim aprender é magnífico, saber das coisas, saber como é que funciona. Até hoje, adoro isso, adoro. Só que para mim, eu sempre tentava aprender e nunca conseguia exatamente aprender, então, sempre faltava alguma coisa, sempre tinha uma lacuna para ser completada. Então sempre me sentia uma criança, meio que vazia, sabe, de conhecimento.

Entrevistadora Claudia: Certo.

Entrevistado Marcelo: Não por falta de esforço, algum defeito.

Entrevistadora Claudia: Aham. E sobre seus professores e colegas você acha que eles, como eles te viam, eles te viam como igual? Como você achava que era o tratamento dos seus professores e colegas em relação a você?

Entrevistado Marcelo: Então, desde pequeno meus professores, eles sempre achavam que eu tinha algum problema, sempre achavam que tinha, ou problema de audição ou de visão. Eu e minha mãe fomos, nossa, milhões e milhões para fazer exames de visão, de audição. Porque os professores falavam eu, por causa da leitura, eu trocava as palavras, eu pulava as linhas muito, então, "'pô', ele está com problema de visão", e quando falava comigo, parecia que eu não escutava, porque eu não entendia, então, "'pô' ele tem algum problema de audição. Eu fui nos médicos, eu nunca tive nada, nada.

Entrevistadora Claudia: Aham.

Entrevistado Marcelo: Então isso era uma visão dos professores, e dos alunos em si, não tinha muita diferença, não. Porque eu acho que ainda mais quando pequeno, existe bastante disparidade, não é? As crianças que vão muito mal também, as que não estudam, aqueles que vão muito bem. Eu sempre fui uma criança mediana, sabe? Sempre 6, 7, nunca tirei um 8, 9 e nem 4, 3.

Entrevistadora Claudia: Certo. Aham.

Entrevistado Marcelo: Então, eu acho que sempre mantive na média, nunca <ininteligível - 0:06:39.3> muita diferença dos meus colegas, mas os meus professores, eles sentiam que tinha que tinha alguma coisa faltando.

Entrevistadora Claudia: Na aula de inglês, enquanto você fazia a aula de inglês, eles sabiam da sua dislexia, ou você dois momentos de saber e não saber, como foi a sua trajetória?

Entrevistado Marcelo: Então, meus professores, eu fui diagnosticado, acho, quando eu tinha 14 anos, mais ou menos. Então passei uma boa parte da minha vida, meio que sofrendo, e o curso de inglês, mais velho, eu voltei a fazer, junto com as criancinhas, tinha começado a tomar o remédio, eles já sabiam desse déficit meu. Só que muitos professores, eles nunca passaram mão na cabeça, nunca... me trataram como um diferente, sabe? Muitas vezes quando eu perguntava, eles davam um pouco mais de atenção na hora da resposta, e 
tentavam sempre descobrir uma maneira, mais fácil de me falar, mais nunca foram tão diferentes, nunca teve um tratamento tão diferente, entendeu?

Entrevistadora Claudia: Nem para o lado positivo, nem para o lado negativo, de modo nenhum te tratavam diferente?

Entrevistado Marcelo: Não. Única coisa que me trataram diferente assim, que foi até bom que foi em questão ao vestibular. Na questão ao vestibular eu tenho direito a fazer a prova separada, não é?

Entrevistadora Claudia: Certo.

Entrevistado Marcelo: Porque eu preciso de uma concentração, para fazer uma prova, ainda mais no caso do ENEM, que é uma prova mais cansativa, mais longa, eu preciso de um tempo maior de prova, que eu tenho também uma hora a mais, e preciso de mais concentração do que todo mundo. Então por isso me deram uma sala separada, essa é a maior diferença que eu tive que eu achei realmente vantagem para mim.

Entrevistadora Claudia: Certo. Isso é legal. "Tá". E só para terminar, como e quando você soube que tinha dislexia, quando foi seu diagnóstico, assim de fato?

Entrevistado Marcelo: Primeiro diagnóstico foi de fato, foi quando, como eu disse, eu sempre fui a vários médicos de visão, audição sabia que tinha problema. Sabe quando eu morava em Belo Horizonte, eu tinha em torno de 13 ou 14 anos, tinha uma psicopedagoga, essa colega de colégio que falou que tinha feito exame de visão, de audição e não tinha dado nada. E ela falou: "nossa que estranho, o Marcelo é um aluno meio disperso, com uma dificuldade e não tem nenhum tipo de problema", daí ela falou que poderia ter alguma coisa neurológica, entendeu?

Entrevistadora Claudia: Aham.

Entrevistado Marcelo: Algo diferente, que não fosse somente visão e audição, porque realmente os exames nunca davam nada. Daí ela sugeriu que a gente fazer um exame neurológico, para ver se encontrava algum tipo de problema, algum tipo de déficit, daí acabou que a gente foi no neurologista, foi em outros médicos, e acabaram me diagnosticando como PPA com déficit de atenção e epilepsia.

Entrevistadora Claudia: Certo. Certo. Isso foi com que você disse, mais ou menos com 14 anos?

Entrevistado Marcelo: Sim, em torno dos 14 anos.

Entrevistadora Claudia: Certo. Sobre o seu aprendizado de inglês, tem mais alguma coisa que você gostaria de mencionar em relação à dislexia, que você tenha se lembrado?

Entrevistado Marcelo: Não. Uma coisa que eu percebi é o seguinte: na escola de inglês foi que, sempre para mim foi difícil aprender, só que agora, aqui em Niterói, eu moro com várias pessoas estrangeiras, e eu convivo com umas pessoas estrangeiras, então acabou que me forçando a falar em inglês. Isso que é forçar a falar em inglês, eu também jogo alguns jogos online que eu tenho que falar em inglês, então eu procuro no dicionário, isso que estou achando que esta me ajudando muito a melhorar um pouco meu vocabulário, a saber o quê que eu falo em inglês, como eu falo, qual é a ordem, coisa que antigamente não tinha, esse poder aprender livremente, parece que está me facilitando mais também, fora que estou mais velho, e tomo remédio que me ajuda a controlar mais também

Entrevistadora Claudia: Certo. Última coisa, quando você fazia nas suas aulas de inglês, nos seus cursos, vocês costumavam avisar o professor previamente, da sua questão da dislexia?

Entrevistado Marcelo: Sim. Eu sempre costumei avisar todos os professores, minha mãe também sempre fez questão, de quando começava o ano, no colégio ou até no cursinho, falar com os orientadores do colégio, falando que eu tinha um problema, entendeu? Que também não era para me tratar como um queridinho sabe?

Entrevistadora Claudia: Sei.

Entrevistado Marcelo: Minha mãe foi de ficar tentando poder me dar maior atenção, sabe?

Entrevistadora Claudia: Uhum.

Entrevistado Marcelo: Mas sempre teve um aviso prévio assim.

Entrevistadora Claudia: Certo. E você achava que isso era bom, te ajudou, você acha?

Entrevistado Marcelo: Eu acho que sim, porque de certa forma, o professor me dava um pouco mais de atenção na hora de explicar. Ah não entendi isso aqui, ao invés de ele explicar a melhor forma ou passar a matéria rápida, ele dava uma atenção ou se na hora ele não me falava, depois ele me chamava e me explicava direitinho como que era. Até eu entender mais ou menos.

Entrevistadora Claudia: Certo. Marcelo e isso aí, Super obrigada.

Entrevistado Marcelo: De nada.

Entrevistadora Claudia: Obrigada mesmo, valeu, são essas as perguntas, então acabamos por aqui.

\section{ANEXO D: TRANSCRIÇÃO - RENATA}

Entrevistadora Claudia: Então está bom, Rosemery. Rosemery,Renata?

Entrevistada Renata: Renata.

Entrevistadora Claudia: Renata. Então, pode me falar assim, muito rapidamente, só o que você faz, a sua idade e de onde você é.

Entrevistada Renata: Eu sou de São Paulo, eu sou psicóloga, trabalho no consultório, psicologia clínica, e tenho 54 anos.

Entrevistadora Claudia: Certo. Então, como eu te disse da outra vez, o meu interesse é sobre o disléxico e o inglês. Mas não se preocupa se você falar de outras coisas, outras experiências, porque está tudo ligado. Se eu voltar e tentar te trazer, é porque é o meu foco. Mas você pode falar de outras coisas, não tem o 
menor problema. Porque a vida da gente é tudo ligado uma coisa na outra. Me fala um pouquinho, como é que você descobriu a sua dislexia?

Entrevistada Renata: Eu descobri com 37 anos, quando eu soube que o meu filho tinha dislexia. Que eu fui fazer o diagnóstico dele e aí me identifiquei, também fiz o diagnóstico e aí foi confirmado.

Entrevistadora Claudia: Olha é a segunda história. A minha entrevista antes de você foi a mesma história. Ele descobriu por causa da filha.

Entrevistada Renata: É muito comum.

Entrevistadora Claudia: É muito comum, não é?

Entrevistada Renata: É.

Entrevistadora Claudia: Interessante. E aí, então, vamos dar uma olhada. Então, pensa. Você estudou inglês além do colégio?

Entrevistada Renata: Então, eu não estudei. Na época do colégio eu não estudei. Era francês que tinha.

Entrevistadora Claudia: Aham.

Entrevistada Renata: Aí, depois é que teve inglês, acho que no colegial. Na época era colegial.

Entrevistadora Claudia: Certo. Aí eu abandonei.

Entrevistada Renata: E aí, eu parei de estudar no... acho que faltava um ano para terminar o colegial.

Entrevistadora Claudia: O inglês ou a escola?

Entrevistada Renata: Os estudos. A escola.

Entrevistadora Claudia: A escola?

Entrevistada Renata: É. Eu achava que... eu não sabia da dislexia. Eu achei que eu não ia conseguir fazer nenhuma faculdade, mesmo. E aí, eu abandonei a escola. Aí eu me casei, tive três filhos e aí descobri com 37 anos, só. Neste período, enquanto as crianças iam crescendo, numa fase... acho que o meu filho que é disléxico, ele tinha acho que uns 5, uns 6, 7 anos, nós decidimos ir para os Estados Unidos.

Entrevistadora Claudia: Uhum.

Entrevistada Renata: E aí, as meninas... eu tenho duas meninas e um menino. As meninas já estavam estudando inglês na Pink and Blue, não sei se você já ouviu falar.

Entrevistadora Claudia: Sei, sim.

Entrevistada Renata: E aí, eu falei para a professora "Olha, vou com eles, não sei falar nada, meu marido também, muito pouco". Então, ela se prontificou a dar algumas aulas para mim e com as crianças. E aí, eu aprendi as coisas de café da manhã. Ela montou uma mesa de café da manhã.

Entrevistadora Claudia: Aham.

Entrevistada Renata: E aí tudo de café da manhã eu aprendi.

Entrevistadora Claudia: Entendi.

Entrevistada Renata: Aí foi bem legal. Aí depois, mais tarde, quando eu fiquei já sabendo que eu sou disléxica, eu voltei a estudar. Eu fui fazer supletivo.

Entrevistadora Claudia: Entendi.

Entrevistada Renata: Aquele supletivo à distância.

Entrevistadora Claudia: Aham.

Entrevistada Renata: E aí, quando chegou também, na matemática, física, química e inglês, eu não conseguia fazer sozinha.

Entrevistadora Claudia: Entendi.

Entrevistada Renata: Aí eu procurei uma professora. E aí também tive algumas poucas aulas de inglês. Então, é essa a minha experiência com professor de inglês.

Entrevistadora Claudia: Entendi. Então, você...

Entrevistada Renata: Mas assim, muito poucas. Acho que, o que? Umas cinco ou seis aulas.

Entrevistadora Claudia: Então, vamos fazer os dois blocos. Na escola, em inglês, você se lembra da sua experiência, como é que você se sentia nas aulas?

Entrevistada Renata: Mal.

Entrevistadora Claudia: Mal?

Entrevistada Renata: Muito mal.

Entrevistadora Claudia: Uhum.

Entrevistada Renata: Eu me sentia. Antes de saber da dislexia, eu achava que eu tinha algum problema neurológico.

Entrevistadora Claudia: Sei.

Entrevistada Renata: Porque, não era só inglês, eram outras matérias também, que eu não ia bem.

Entrevistadora Claudia: Sei.

Entrevistada Renata: Que eu tinha muita dificuldade. Mas no inglês, então, me dava uma agonia, assim, uma sensação de impotência.

Entrevistadora Claudia: Certo, certo. Você se lembra, no colégio, se havia alguma atividade específica onde você se sentia mais impotente, assim? Ou era geral?

Entrevistada Renata: Matemática e inglês.

Entrevistadora Claudia: E em inglês, tinha alguns momentos em que você se sentia pior? Ou era a aula em geral?

Entrevistada Renata: Em geral.

Entrevistadora Claudia: Em geral? 
Entrevistada Renata: Tinha pânico só de falar que ia ter aula de inglês.

Entrevistadora Claudia: Sério? Entendi. E aí, como que foi com a professora?

Entrevistada Renata: Nem lembro da cara da professora. Essa da escola, apagou.

Entrevistadora Claudia: Nem lembra?

Entrevistada Renata: Olha, a de francês, eu até ainda lembro do rostinho dela. Eu acho que ela era uma professora mais paciente, sei lá. Ou era menor a dificuldade. Porque o francês dá para a gente... lembra alguma coisa do português.

Entrevistadora Claudia: Ajuda, não é?

Entrevistada Renata: É. Então, não era tanto, mas de inglês, eu não me lembro nem quem que me dava aula de inglês.

Entrevistadora Claudia: Gente do céu.

Entrevistada Renata: Apagou.

Entrevistadora Claudia: Bom, você nem sabia no colégio que você tinha dislexia, não é?

Entrevistada Renata: Não.

Entrevistadora Claudia: Então, não tinha como falar. Depois, quando você foi fazer essas aulinhas aí, rapidinhas, você acha que foi melhor, com a professora particular? Foi professora particular, imagino.

Entrevistada Renata: Era particular, eu ia na casa dela.

Entrevistadora Claudia: E aí foi um pouco melhor?

Entrevistada Renata: Ela me dava uma lista. Ela era assim, bem catedrática, sabe?

Entrevistadora Claudia: Aham.

Entrevistada Renata: E aí, ela me dava umas listas para eu levar para casa para decorar.

Entrevistadora Claudia: Certo.

Entrevistada Renata: Não era um método muito eficaz para a minha pessoa.

Entrevistadora Claudia: Certo. E como é que você se sentia? Dava certo? Não funcionou?

Entrevistada Renata: Me sentia mal. Não dava assim muita atenção, não, porque eu também tinha outras coisas para estudar.

Entrevistadora Claudia: Sim.

Entrevistada Renata: E assim, eu não dava muita atenção, mas eu sabia que eu precisava, porque eu precisava passar para tirar o diploma.

Entrevistadora Claudia: Aham.

Entrevistada Renata: Aí, o dia que eu cheguei lá, ela quis me fazer chamada oral. Eu pensei: "alguém precisa tirar minha burrice". Eu nunca tinha ouvido essa expressão. Tranquilo.

Entrevistadora Claudia: Aham.

Entrevistada Renata: E eu tinha, "Nossa Senhora, onde eu fui me meter". E aí, assim, eu não me sentia confortável, não.

Entrevistadora Claudia: Aham. Existia, com ela, na aula particular, alguma atividade de inglês específica com a qual você se sentia pior, mais desconfortável?

Entrevistada Renata: Na hora de ler.

Entrevistadora Claudia: Ler. Ler é o problema, não é?

Entrevistada Renata: É. Lê e não entende nada do que você está lendo.

Entrevistadora Claudia: Uhum.

Entrevistada Renata: Já tem a dificuldade de ler em português.

Entrevistadora Claudia: Sim.

Entrevistada Renata: Aí, para ler em inglês, então, que é diferente a pronuncia, tudo.

Entrevistadora Claudia: Tudo.

Entrevistada Renata: Assim, mas eu não acho que eu seja muito acanhada, eu sou meio cara de pau.

Entrevistadora Claudia: Sei.

Entrevistada Renata: Eu até enfrento o problema, vou. Mas era muito desconforto.

Entrevistadora Claudia: Sei. Sensação de desconforto.

Entrevistada Renata: É.

Entrevistadora Claudia: Para essa professora particular, você chegou a dizer que era disléxica ou

não?

Entrevistada Renata: Sim, nessa época ela já sabia. Eu já sabia e ela já sabia. Mas eu ainda não tinha muito a dimensão disso. Acho que quando eu fui fazer isso, fazia muito pouco tempo...

Entrevistadora Claudia: Aham.

Entrevistada Renata: ... que eu sabia sobre a minha dislexia e o que era a dislexia.

Entrevistadora Claudia: Certo, certo.

Entrevistada Renata: Estava descobrindo.

Entrevistadora Claudia: Entendi, estava muito no começo.

Entrevistada Renata: É.

Entrevistadora Claudia: Hoje, quando você pensa em inglês, o quê que você pensa?

Entrevistada Renata: Eu acho que é a parte para mim, eu acho que é apaixonante, porque eu amo música em inglês.

Entrevistadora Claudia: Aham.

Entrevistada Renata: E assim, eu sei que quando eu ouço uma música, eu entendo assim, 0,1\% de palavras.

Entrevistadora Claudia: Certo. 
Entrevistada Renata: Quando a gente consegue entender a palavra, porque às vezes a gente nem entende a pronúncia ou... sei lá.

Entrevistadora Claudia: Uhum.

Entrevistada Renata: Às vezes o cantor também não fala a música expressivamente, corretamente, sei lá. Mas, 0,1\% eu acho que eu entendo. E eu adoro.

Entrevistadora Claudia: Aham. admiradora.

Entrevistada Renata: Eu sou uma consumista de música. Consumista não é a palavra certa. Mas

Entrevistadora Claudia: Certo, certo. Mas você pensa em, por exemplo, quando você pensa, você pensaria em voltar a estudar?

Entrevistada Renata: Então, eu para confessar sério para você, penso. Toda vez que eu ligo o rádio, eu ouço uma música em inglês, eu até penso em voltar, tenho essa vontade. Mas ela passa rapidinho. Passa muito rápido, porque que sei o quanto difícil é para mim.

Entrevistadora Claudia: Entendi.

Entrevistada Renata: É uma preguiça, uma preguiça inominável.

Entrevistadora Claudia: Entendi.

Entrevistada Renata: Aí eu me lembro, na hora em que eu estou ouvindo, mas aí depois eu já desisto.

Entrevistadora Claudia: Entendi, entendi. Que interessante. Então, fica esse jogo da vontade...

Entrevistada Renata: Do desejo.

Entrevistadora Claudia: ...e do correr dela.

Entrevistada Renata: É. Tenho desejo naquele momento, mas aí, depois, o dia a dia vai acontecendo, as coisas vão se passando. E aí, eu já perco assim, o desejo, rapidinho. disléxico?

Entrevistadora Claudia: Que interessante. Como que você se definiria? Para você o que é ser

Entrevistada Renata: Como?

Entrevistadora Claudia: O quê que é para você, na sua vida, se você fosse se definir?

Entrevistada Renata: Eu sou uma pessoa normal.

Entrevistadora Claudia: Aham.

Entrevistada Renata: Hoje, depois de 14 anos de terapia.

Entrevistadora Claudia: Certo. desabilidades.

Entrevistada Renata: Eu me sinto uma pessoa normal. Sei das minhas habilidades e das minhas

Entrevistadora Claudia: Certo.

Entrevistada Renata: E eu considero a dislexia uma dessas minhas desabilidades.

Entrevistadora Claudia: Aham.

Entrevistada Renata: Mas eu sei que eu tenho outras habilidades muito mais aguçadas de que outras pessoas que não têm dislexia.

Entrevistadora Claudia: Entendi.

Entrevistada Renata: Eu entendo isso.

Entrevistadora Claudia: Certo.

Entrevistada Renata: Hoje eu tenho essa convicção.

Entrevistadora Claudia: Você já entendeu essa...

Entrevistada Renata: Sim.

Entrevistadora Claudia: E aí, imagino que a frustração fica... ou ela desaparece ou ela fica bem menor, quando você entende isso, não é?

Entrevistada Renata: Fica bem menor e, assim, fica entendível.

Entrevistadora Claudia: Entendi.

Entrevistada Renata: Porque eu costumo dizer que tem dias que a dislexia ataca mais, ela está mais aflorada.

Entrevistadora Claudia: Ah... Que interessante.

Entrevistada Renata: E aí, eu vou escrever alguma coisa, que nem hoje mesmo, eu fui escrever uma mensagem no celular. Hoje em dia eu já não escrevo tanto.

Entrevistadora Claudia: Uhum.

Entrevistada Renata: Mas, tem hora que a dislexia ataca e dá, assim, uma insegurança na hora de escrever.

Entrevistadora Claudia: Certo.

Entrevistada Renata: Aí eu fui escrever uma palavra, e aí eu perguntei para a pessoa que estava do meu lado. Nossa, eu não me lembro mais a palavra. "Essa palavra é com 's' ou com 'c'?" Aí a pessoa deu risada, sabe do meu problema. Problema, não. Não é problema, sabe da minha dislexia. E ela riu e falou "É com 's'." Eu falei, "Ah, então eu escrevi certo". Mas eu tenho essa insegurança.

Entrevistadora Claudia: Aham.

Entrevistada Renata: E ainda bem que no celular tem o corretor de texto.

Entrevistadora Claudia: O corretor ajudou muito, não é?

Entrevistada Renata: Ajuda muito. Ás vezes ele faz a gente passar vergonha, porque escreve outra coisa completamente errada. Por isso tem que prestar muita atenção antes de mandar a mensagem.

Entrevistadora Claudia: Aham. 
Entrevistada Renata: Mas aí, a gente vai aprendendo.

Entrevistadora Claudia: Mas até aí o corretor está colocando todo mundo em enrascada, não é só o disléxico, porque todo mundo escrevendo besteira.

Entrevistada Renata: É, é. Mas aí às vezes quem está lá é porque não considera erro.

Entrevistadora Claudia: Certo, certo. Exatamente. Aham. Certo. E as suas filhas? A dislexia é leve, como é que está?

Entrevistada Renata: Então, é o meu filho.

Entrevistadora Claudia: Seu filho.

Entrevistada Renata: A dislexia é leve.

Entrevistadora Claudia: Aham. Entendi. Que bom. Mas que interessante. Olha, eu queria te agradecer. Você me deu uns insights maravilhosos.

Entrevistada Renata: Que bom.

Entrevistadora Claudia: Muito obrigada. Deixa eu só desligar a gravação, mas eu... 


\section{ANEXO E: TRANSCRIÇÃO - RUBENS}

Entrevistadora Claudia: Então, "tá". Rubens só fala para mim, rapidamente, o que você faz, sua idade, de onde você é.

Entrevistado Rubens: Eu sou de São Paulo, na verdade eu nasci em Minas, mas minha vida inteira morei aqui, em São Paulo. Eu tenho 44 anos, mas eu falo sempre que eu estou com 40. Ah, tudo 40.

Entrevistadora Claudia: Tudo 40. Arredonda. Arredonda.

Entrevistado Rubens: Cada vez vai ficando mais difícil. E eu trabalho com informática, eu sou gerente de sistemas de uma startup.

Entrevistadora Claudia: Ok.

Entrevistado Rubens: Aonde eu sou sócio também. Não tenho grandes... Não, a minha vida é bem, bem simples.

Entrevistadora Claudia: Tranquila.

Entrevistado Rubens: Trabalho e não tenho muitas aventuras, não.

Entrevistadora Claudia: Me fala como que você descobriu a dislexia, qual foi o momento da sua vida?

Entrevistado Rubens: Então, eu descobri... como eu te falei, a Fernanda pequena assim com 5, 6 anos, ela era muito agitada. Aí eu li uma matéria sobre dislexia, que falava sobre esse comportamento de agitação nas crianças e tal. Era um dos sintomas que eu percebia, a Fernanda muito agitada. Aí eu falei "Ah, vou ligar". Aí escutei uma entrevista da Ângela na rádio e fui na ABD, assim, pensando na Fernanda, minha primeira filha. Quando eu conversei com a Mônica, que é a psicóloga que me atendeu, ela falou: "Cara, normalmente o filho para ser disléxico tem que ter uma matriz, não é?". Bom, vou falar da Fernanda depois. Aí ele fez uma meia dúzia de perguntas, eu falei sim para todas. Pronto, já praticamente estava diagnosticado.

Entrevistadora Claudia: Certo, e isso então foi recente, faz quanto tempo?

Entrevistado Rubens: Não. Isso foi em 2009, não desculpa, em 99, já faz aí 16 anos.

Entrevistadora Claudia: Ah, sua filha tem 16 anos.

Entrevistado Rubens: Nanda tem 20.

Entrevistadora Claudia: Certo, certo. Então a sua vida escolar, ela foi toda sem saber que você era disléxico.

Entrevistado Rubens: Foi. Eu tive diagnóstico com 28. E aí, eu fiz todos os exames lá, os procedimentos na ABD e detectou uma dislexia moderada.

Entrevistadora Claudia: Certo, certo.

Entrevistado Rubens: Com afetamento muito na parte de disgrafia. E eu não tenho muito problema com dicção, com a parte de Fono que afeta também. Então é mais escrita e leitura. Eu passei sim, a parte de alfabetização até onde eu me lembro que eu estudei, foi bem afetada pela dislexia. E já foi logo de cara assim, no primeiro ano da primeira série, eu estudava em escola pública, meus pais não tinham muitos recursos, e aí logo no primeiro ano... Primeiro que eu não sabia o que eu estava fazendo escola, ninguém me dizia o quê que era para fazer lá, entendeu? E era um negócio confuso, que algumas coisas eu entendia. Enquanto eu não entrei na alfabetização até que era legal, fazia desenho, fazia aqueles exercícios para motricidade, não é?

Entrevistadora Claudia: Era divertido.

Entrevistado Rubens: Mas quando entrou a alfabetização pesou. Tinha uma menina que sentava na minha frente, que chegou uma parte do ano ela até saiu, tadinha. Porque ela não me aguentava mais assim, eu perguntava as coisas...

Entrevistadora Claudia: O que você fazia, interrompia a aula, perguntava?

Entrevistado Rubens: Interrompia, não prestava atenção e perguntava tudo para ela, porque eu não estava entendendo, não é? Eu várias histórias hilárias assim. A vantagem é que como eu não sabia de nada, eu passei um pouco assim... Não é que não teve trauma, teve. Muitos traumas. Mas aí, eu ia superando, vai. Dava um trauma, ah, vamos para o próximo.

Entrevistadora Claudia: Certo. Então o quê que era um trauma para você? Como que você sentia, o que você considerava um momento difícil?

Entrevistado Rubens: É, porque o problema da dislexia, hoje eu tenho essa consciência, na época não tinha, é você saber que você é capaz. E como na escola tudo é medido pelo que você consegue reproduzir do que você aprendeu. Você fica muito prejudicado, não é? Porque você sabe que é capaz, sabe que é melhor do que um monte de gente. Então assim, "Eu não acredito que esse cara, aquela pessoa ou aquele menino pode ser considerado melhor que eu, sendo que eu sou muito melhor que ele". É difícil, porque lá é tudo formatado, você só é medido pelo seu output do que aprendeu. Escrita, ou do que você leu, o que você entendeu, é super difícil. E aí afeta, por exemplo, leitura e interpretação de texto, vai afetando outras áreas do ensino. Então você consegue fazer uma conta, só que para resolver um problema, uma equação, você tem que entender o que está escrito lá. Se você não entende o enunciado você não consegue nem montar a conta. $E$ aí vai, uma coisa vai engatando na outra. Você pode ser muito bom de ciências, só que você escreve as palavras erradas. Aí cada meio ponto que você perde, ao invés de ser um 10 vira 5 . E aí começa a virar tudo uma frustração, porque nada do que você produz tem valor, e quando comparado ao que os outros estão produzindo. $E$ aí, você começa a se questiona muito, porque você sabe da tua capacidade e você vê o cara do lado que é nitidamente inferior a você, inferior assim... Dentro do que você considera habilidade, ele ser julgado como melhor. E é complicado, aí que vem os rótulos, não é? De preguiçoso, de burro, de tudo que você pode imaginar. Aí é um massacre constante. O que vai acontecendo? Você perde o interesse por aquilo. Você fala assim: "Meu, esse é um jogo idiota, é o jogo de regra babaca". E aí o que você começa a fazer? Você começa a burlar regras. Você fala: "Meu, é uma regra tão idiota que eu vou burlar todas elas. Pronto. Eu sou mais inteligente do que todo mundo que está aqui dentro, inclusive, que a professora". Aí começa a burlar e você vai pegando via atalho, você faz de tudo. Só que 
você é sempre uma espécie de fora da lei, entendeu? Sempre está fazendo coisa errada. E aí vem cobrança, meu, é um massacre constante.

Entrevistadora Claudia: Você consegue, então, se lembrar... Mesmo na época de escola, ou depois mais velho, a sua vivência com inglês? Como que foi inglês?

Entrevistado Rubens: Então, inglês sempre foi terrível, porque eu acho que o inglês ele tem, para mim, o componente que é... Primeiro: você escreve diferente do que você fala. Já começa por aí.

Entrevistadora Claudia: Até eles têm problema com spelling.

Entrevistado Rubens: Exatamente. E eu acho que o problema da memória, tanto a memória imediata como a memória de longo prazo, ela torna o aprendizado muito maçante. E aí, você perde o interesse por aquilo, que é uma coisa que acontece normalmente com o disléxico, não é só com inglês. Qualquer coisa que ela é maçante, ela se torna desinteressante.

Entrevistadora Claudia: Você disse que você estudou inglês fora da escola, não é? No Instituto de língua.

Entrevistado Rubens: Sim, estudei. Na escola não posso nem considerar que eu tive inglês na escola. Porque a minha escola era pública, era péssima, não é?

Entrevistadora Claudia: Certo.

Entrevistado Rubens: E eu parei de estudar na sexta série do ensino fundamental porque eu decidi que a escola não servia para nada, não é? Falei "Bom, vou aprender sozinho".

Entrevistadora Claudia: Certo.

Entrevistado Rubens: E depois eu voltei. Muito tempo depois, de várias formas. Você tenta fazer o inglês em 6 semanas, inglês pela internet, pelo livro, por não sei o quê. E o período que eu consegui ter uma disciplina maior para o inglês foi meados de 2006, 2007, eu cheguei a fazer três períodos na Wizard. A Wizard tem uma metodologia que me interessou um pouco que é muita repetição, não é?

Entrevistadora Claudia: Certo.

Entrevistado Rubens: Você fica lá, repete, repete, repete. Para o disléxico isso é até bom, porque meio que cria uma forma de memorizar boa parte das coisas. Mas, ao mesmo tempo, é desinteressante, porque o processo para que você consiga obter resultados, que seria poder falar e até entender, ele se torna muito longo, muito... como que eu falo? Muito demorado, e aí volta aquela impaciência que o disléxico tem. Não quer ficar ali, a coisa demorada.

Entrevistada: Então pensando na Wizard, nas tentativas fora da escola, Instituto de 6 meses, 8 semanas, onde você sentia mais dificuldade. "'Putz', eu tenho que aprender essa língua". Quais eram seus maiores problemas? Onde você ficava mais frustrado ou o que te causava mais problema? Atividades de sala ali para aprender a língua.

Entrevistado Rubens: Então, eu acho que é mais a parte de... Como é que eu diria? Você diz onde eu me frustrava?

Entrevistadora Claudia: É, vou te dar umas idéias. Vamos supor, leitura. Era ok?

Entrevistado Rubens: Não, leitura sempre complicada. Português é complicado, inglês pior.

Entrevistadora Claudia: Vocabulário. Decorar vocabulário?

Entrevistado Rubens: Não é tão complicado. Quando você só tem que falar ou quando você tem que aprender pela repetição, que a Wizard faz muito, no começo ela não tem muita gramática, não é? São só aquelas aulas ali, você vai aprendendo palavras e depois você começa a fazer as composições para... Como se fala? Para compor frases, situações.

Entrevistadora Claudia: Como você se sentia, por exemplo, eu não sei se essa escola fazia isso, por exemplo, quando a professora pedia para ler algo em voz alta. Eles tinham o costume de fazer isso? "Rubens, leia este parágrafo".

Entrevistado Rubens: Não, não tinha esse costume, mas nunca me senti bem porque sempre tem a dificuldade da pronúncia, do entendimento das palavras.

Entrevistadora Claudia: Trabalhos em pares, diálogos? Como que era?

Entrevistado Rubens: Era, tranquilo, eu nunca tive problemas em trabalhar em time, equipe, quando existe colaboração mútua, não é?

Entrevistadora Claudia: Certo. Ah, isso é uma informação interessante. Escrita era um problema?

Entrevistado Rubens: Sempre é problema. Por que qual que é o problema da escrita para o disléxico? É lembrar da palavra, da grafia, não é?

Entrevistadora Claudia: Os professores sabiam? Você falava? Por que aí você já sabia da dislexia, não é? Ou não?

Entrevistado Rubens: Já, já sabia. Mas eu não entrei no mérito com eles com relação à dislexia.

Entrevistadora Claudia: Alguma razão especial ou por que...

Entrevistado Rubens: Não, acho que nunca me veio essa preocupação, para mim já estava meio que acomodado, que eu teria mesmo que vencer a dificuldade e não usar a dislexia como muleta. Até por exemplo, fugindo um pouco do inglês, eu nunca estudei espanhol, mas eu estive um tempo na América Latina trabalhando e aprendi muito rápido. Acho que em questão de 2 meses eu falava espanhol quase que fluente. Só falava, não escrevia e lia... Lê eu até consigo ler, mas escrever já é mais complicado também. $E$ aí o engraçado é que o aprendizado do espanhol, ele foi muito nessa condição lúdica. Eu fui para lá trabalhar, não sabia falar uma palavra em espanhol, mas nas primeiras duas ou três semanas eu acompanhei muitas reuniões com o cara que trabalhava comigo e falava bem espanhol, em vários países diferentes. Então tinha cada um com sotaque, cada um com uma cultura, não é? Na verdade, eu aprendi espanhol porque estava a fim de aprender espanhol, eu aprendi espanhol porque eu achei várias coisas interessantes no conjunto daquele momento. E inclusive as 
inúmeras reuniões que eu participava com ele, reuniões comerciais que começavam logo cedo, no café da manhã, e passava por todos os cenários até a janta e depois o happy hour à noite, aonde a língua, o espanhol, ele vinha naturalmente, no meio de um contexto. Então, na verdade, isso é uma coisa que eu acho muito interessante. Ele vinha como complemento de tudo o que estava acontecendo em volta e a língua não era o principal foco. E foi lúdico e foi um aprendizado muito rápido, eu diria relâmpago. E eu sonho que o inglês podia ser um aprendizado dessa forma, entendeu?

Entrevistadora Claudia: Então já que você trouxe de volta o inglês, se você pudesse descrever a sua experiência com o inglês, a sua sensação, como que você se sentiu, se sente hoje? Como foi? O que você me diria?

Entrevistado Rubens: Ah, o problema, a sensação com o inglês é um pouco frustrante por não conseguir dominar ele. Eu vejo a língua inglesa da mesma forma que eu via as aulas de português na escola. Eu não conseguia dominar o português por causa das regras, por causa do formato, e aquilo sempre me causava desinteresse. E aí, eu comparando inglês com o espanhol, é a mesma coisa que comparar o português com a linguagem codificada do computador. Não vejo dificuldade nenhuma em aprender inúmeras linguagens e eu desenvolvo vários projetos. É muito engraçado isso. Como que eu não consigo ler o português, mas consigo ler quase um código cifrado de máquina sem nenhuma dificuldade. Então o inglês tem, para mim, essa característica parecida com a frustração que eu tive no aprendizado do português.

Entrevistadora Claudia: Certo.

Entrevistado Rubens: E aí, eu volto sempre a bater um pouco naquela tecla que eu te falei do espanhol. Essas coisas que eu aprendo com muita facilidade, nem sempre eu estou focado naquilo, eu sempre tenho um contexto. É como se fosse uma moldura meio lúdica e o que de fato eu aprendo ele está ali integrado naquele contexto. É muito difícil de explicar porque...

Entrevistadora Claudia: Não, mas faz sentido, faz sentido.

Entrevistado Rubens: ...na minha cabeça, não é? Não sei se todo disléxico tem essa característica.

Mas...

Entrevistadora Claudia: Como é o seu inglês hoje? Você conseguiu? Você está satisfeito?

Entrevistado Rubens: Não, péssimo. Eu não entendo nada de inglês. Eu sei o básico, muito básico. Não consigo ler, não consigo falar.

Entrevistadora Claudia: Uhum.

Entrevistado Rubens: Entendo assim muito pouco. Eu acho que da mesma forma que teve em algum momento, no início da minha alfabetização, algum tipo de trauma ou trava com relação ao aprendizado convencional, seja de português, do tivesse lá pra aprender na escola, eu devo ter passado por isso com o inglês também. E aí já não sei nem se isso é uma questão de aprendizado ou até de tratamento psicológico.

Entrevistadora Claudia: Sim, sim.

Entrevistado Rubens: Para tirar essa trava.

Entrevistadora Claudia: Não, e é interessante. É bem isso mesmo. Então, para gente fechar, se eu te perguntar assim "O que é ser disléxico?" O que você me fala? Qual que é a sua definição, para você, de disléxico?

Entrevistado Rubens: Olha, disléxico é como se você vivesse num mundo onde todo mundo se comunica através da música e você não conseguisse aprender a música. Disléxico é o seguinte, imagina que ao invés da gente falar ou escrever, a gente tocasse um instrumento e se comunicasse através de notas musicais? Teríamos poucas pessoas no mundo que seriam consideradas aptas a se comunicar, não é? Todo o resto seria burro.

Entrevistadora Claudia: Sim, e bem burro, não é?

Entrevistado Rubens: Exatamente. A dislexia é um pouco isso. Ela meio que te limita em alguns aspectos, mas em outros, você não tem limite, você tem uma capacidade de raciocínio que cria uma dualidade. Então, por exemplo, as pessoas falam: "não, não é possível, não acredito que você acha que você é burro, que você não sabe isso, não sabe aquilo. Pela inteligência que você tem, pelas coisas que você faz. É impossível você ficar se limitando, se definindo como limitado e tal". E dislexia tem essa dualidade, ela te dá um potencial que o mundo que a gente vive, ele não é um diferencial tão grande. Porque, na verdade, as pessoas estão todas na mesma faixa. Elas se comunicam com os mesmos métodos, os mesmos símbolos, e as mesmas formas. Então existe, assim, um nivelamento através da escrita e da leitura e da fala, não é?

Entrevistadora Claudia: Uhum. Certo, certo.

Entrevistado Rubens: É onde todo mundo se equilibra. O disléxico, ele destoa disso, ele está fora. Primeiro ele não se encaixa nesse padrão que é considerado o senso comum e o potencial que ele tem a mais, muitas vezes não é aproveitado, porque as outras pessoas também não estão na frequência dele. Então, você vive uma dualidade, não é?

Entrevistadora Claudia: Uhum. Uhum. Muito interessante.

Entrevistado Rubens: Você é um quadrado tentando se encaixar no círculo.

Entrevistadora Claudia: Aquele joguinho de criança, não é? Que tem o círculo.

Entrevistado Rubens: Está tentando pôr quadrado no círculo o tempo todo. Ao mesmo tempo, que você se frustra com essa, não pejorativamente falando, mas a mediocridade do ensino, de como as pessoas se portam, você também não consegue se descolar disso. Porque é você contra o mundo, entendeu?

Entrevistadora Claudia: Uhum.

Entrevistado Rubens: Você até se revolta, não vai mais para a escola, aprende as coisas sozinho. Mas não tem jeito, no dia a dia você tem que conviver com pessoas que seguem esse fluxo, que seguem essas regras, não é? 
Entrevistadora Claudia: Certo, certo. Perfeito. Rubens, super obrigada.

Entrevistado Rubens: De nada. [Você é que diz].

Entrevistadora Claudia: Foi perfeito, deixa desligar aqui,

\section{ANEXO F: TRANSCRIÇÃO - TIAGO}

Entrevistado Tiago: Não se preocupe porque aqui tem 30Mega.

Entrevistadora Claudia: Ah, então está bom. Tiago, só o seguinte, então, vamos começar a entrevista. Só me fala, por favor, quantos anos você tem, o que você faz hoje, se você estuda, trabalha.

Entrevistado Tiago: Eu tenho 26 anos. Eu trabalho no Senac da Tito. Já fiz curso de Excel Avançado e pretendo fazer Técnico de Informática ano que vem.

Entrevistadora Claudia: E você trabalha com informática?

Entrevistado Tiago: Não, eu trabalho na biblioteca.

Entrevistadora Claudia: Ah, "tá". Certo.

Entrevistado Tiago: No Senac.

Entrevistadora Claudia: Certo, então está bom. Um dos motivos da gente... que a Ana mencionou para mim que você tem dislexia, certo?

Entrevistado Tiago: Certo.

Entrevistadora Claudia: Como que você descobriu? Como foi?

Entrevistado Tiago: Eu descobri quando eu era menor e, assim, quando eu comecei a escrever. Eu troco muito as letras.

Entrevistadora Claudia: Certo.

Entrevistado Tiago: Aí uma vez me falaram que era dislexia e tal. Aí foi quando constataram que eu tinha dislexia. Aí até hoje, às vezes, eu troco alguma coisa, mas eu tento me corrigir.

Entrevistadora Claudia: Certo. E você lembra quantos anos você tinha quando você descobriu assim, te deram esse toque?

Entrevistado Tiago: Nossa, faz muito tempo.

Entrevistadora Claudia: Você era criança, bem pequeno?

Entrevistado Tiago: É assim, eu não lembro mesmo. Além da dislexia, foi constatado também que eu tinha a DDA com agressividade.

Ana: Que é o oposto <ininteligível - 0:01:57.0 > com hiperatividade. <Ininteligível - 0:02:03.3>.

Entrevistadora Claudia: Certo. Então Ana, vou pedir uma coisa, para você não dar a resposta senão a entrevista dele não vai valer.

Ana: [Então, está bom]. Eu vou escovar os dentes agora.

Entrevistadora Claudia: Não, mas pode ficar aí...

Ana: <Ininteligível - 0:02:17.5 >aqui rapidão.

Entrevistadora Claudia: Está bom. Então "tá", Tiago. Isso aí a gente já tem, pronto. Então me fala, na escola, me fala um pouco da sua história com o inglês. Você estudou inglês na escola, claro. E o que mais? Você já fez inglês fora?

Entrevistado Tiago: Então, eu nunca me interessei muito por fazer inglês fora da escola. Eu só me interessei quando eu comecei a trabalhar, com 21 anos. Aí eu fui tentar fazer na Seven Idiomas. Falei com minha mãe, ela topou para ver se a gente fazia um teste e tal. Eu tentei acompanhar, mas eu não consegui acompanhar o básico.

Entrevistadora Claudia: Então vamos pegar por aí. Por quê que você acha, o quê que você sentia, por quê que você não conseguiu acompanhar?

Entrevistado Tiago: Então, o básico era alguns meses. Alguns meses era muita informação para pouco tempo, para eu pegar.

Entrevistadora Claudia: Entendi.

Entrevistado Tiago: E no intermediário ela queria que eu já falasse um pouco mais de inglês e eu não conseguia acompanhar a turma, não conseguir passar na prova, não é? Aí eu pedi desculpa lá na escola, infelizmente não deu por conta das dificuldades de ensino que eu tenho. E foi assim. Aí a minha mãe, ela conheceu uma pessoa, porque ela trabalha na CETESB, que fazia inglês particular. Então ela contratou essa pessoa para me dar aula aqui em casa.

Entrevistadora Claudia: Certo. E é melhor?

Entrevistado Tiago: Então, é bem melhor, porque eu não preciso estar no ritmo de várias pessoas, eu estou no ritmo do meu ritmo, que é um pouco mais devagar. E assim, a dinâmica é bem mais fácil, tem umas coisas que têm mais figuras que é mais fácil para eu decorar. Que devido a minha falta de atenção, que às vezes me atrapalha, por conta disso se tiver umas fotos ou alguma coisa assim é mais fácil para eu identificar aquilo, não é?

Entrevistadora Claudia: Entendi. Você consegue lembrar de atividades específicas na época que você estava nessa escola, por exemplo, e que você sentia dificuldade, e você não consegui seguir, que te deixava às vezes chateado, alguma coisa? Que tipos de atividades eram mais complicadas para você?

Entrevistado Tiago: Então, o que eu achei mais complicado, o que mais complicou para mim, foram os nomes dos... Por exemplo, cada lugar da casa tinha um nome e tinha os móveis, não é? Isso para mim foi o que mais pegou, eu não conseguia pegar isso direito.

Entrevistadora Claudia: Então, você poderia dizer que é vocabulário? Aprender vocabulário? 
Entrevistado Tiago: Isso, vocabulário desses itens. Por exemplo, bedroom, essas coisas que eu posso dizer que agora eu sei o que é, que na época para mim foi complicado de eu entender.

Entrevistadora Claudia: Entendi. E aí quando você faz aula particular você acha que ajuda a decorar vocabulário? É mais fácil?

Entrevistado Tiago: É mais fácil. Eu já passei do segundo nível, eu estou no segundo nível. Considerado básico ainda, mas algumas coisas que eu não entendia no inglês que agora para mim não precisa mais de tradução que eu entendo. Que a meu ver são coisas bobinhas assim, que chego até a achar engraçado de vez em quando, que eu não entendia.

Entrevistadora Claudia: É sim. Voltando então, vamos sempre tentar comparar. Lá na escola, me diz como que era para você escrever em inglês. Prova, redação, atividades de escrita.

Entrevistado Tiago: Atividades de escrita? Bom, redação, na escola em si... É que faz muito tempo que me formei, não é?

Entrevistadora Claudia: Ah, não, mas na Seven, quando você fazia. Tenta lembrar desse curso que você fazia. Como é que era, por exemplo, porque imagino que você tenha tido provas, o seu professor te dava redação. Escrever em sala de aula, como que eram para você atividades de escrita.

Entrevistado Tiago: Então, atividades de escrita para mim não era tão complicado, para mim era um pouco complicado de entender e um pouco de falar. Dificuldade é essa, na escrita não tanto. Mas de entender e falar às vezes tem uma... Até quando eu falo com a minha professora... esses dias eu tive aula de falação. Às vezes também, eu esqueço de algumas coisinhas que até pergunto para ela, "não entendi", aí ela dá uma reforçada, mas aí...

Entrevistadora Claudia: Ótimo, não, perfeito. Você consegue se lembrar de mais alguma coisa nessa época da Seven, que te dava dificuldade? Deixa eu mudar minha pergunta. Em que momento você decidiu sair, tipo você falar: "isso não dá, eu preciso tentar uma aula particular, isso não está funcionando".

Entrevistado Tiago: Foi no momento da prova mesmo. Eu tentei fazer lá, eu acho que foi assim, uma coisa... Um período muito curto para absorver muita coisa. Realmente não consegui aplicar isso na prova.

Entrevistadora Claudia: Entendi. Uhum. Entendi. Você chegou a informar em algum momento na sua vida escolar, por exemplo, na Seven, que você tinha dislexia?

Entrevistado Tiago: Então, eu cheguei a informar, a falar que eu tinha certa deficiência. Porque eu queria provar para mim mesmo se eu era capaz de alguma coisa, não é? Se eu ia conseguir ou não fazer alguma coisa, digamos normal. Mas aí acabei me atrapalhando com isso.

Entrevistadora Claudia: Entendi. Aham. Então na sua opinião, quando você tenta no seu aprendizado de inglês, o quê que a dislexia influência? não é tão alto.

Entrevistado Tiago: Minha dislexia? Ah, deixa eu ver. Hoje em dia ela não influência muito. Meu nível

Entrevistadora Claudia: Entendi.

Entrevistado Tiago: Que eu vou falando, você vai treinando a escrita, a fala, você vai diminuindo. Mas antigamente era um pouco difícil, às vezes, quando eu estou escrevendo alguma coisa, eu esqueço de colocar uma letrinha eu vou lá apago e...

Entrevistadora Claudia: Certo. fome hoje".

Entrevistado Tiago: Até eu dou até uma risada e falo para professora: "ah, eu acho que eu estou com

Entrevistadora Claudia: "Estou comendo letra".

Entrevistado Tiago: É estou comendo letra.

Entrevistadora Claudia: Como que você se sentia? Qual foi a sua sensação, qual era a sua sensação em sala de aula, perante as dificuldades que você sabia que vinham do fato de você ser disléxico?

Entrevistado Tiago: Bom, quando eu descobrir, que não foi meio por médico, foi em redes sociais que eu acabei pesquisando e tal, eu fiquei meio chateado, sabe? Eu fiquei meio para baixo assim. Porque tinha pessoas às vezes... Eu escrevia e as pessoas começavam a dar risada. Eu ficava chateado, aí quando descobri isso eu falava: "não, mas é que eu tenho dislexia". Aí o pessoal falava: "desculpa e tal". Aí eu "Não, tudo bem". Mas aí, conforme eu escrevo, eu vou melhorando. Até, hoje em dia, até em rede sociais eu estou procurando escrever corretamente, não é? Não mais tipo "vc". Eu estou procurando escrever a palavra completa porque isso pode me ajudar muito na escrita.

Entrevistadora Claudia: Uhum. Entendi.

Entrevistado Tiago: Não só no inglês, mas no português também.

Entrevistadora Claudia: Não, com certeza ajuda para os dois lados, não é? Exatamente. E se eu te perguntasse, se eu pedir para você definir, você como um disléxico, o que é ser disléxico para você? Como que você definiria?

Entrevistado Tiago: Olha, agora eu não sei.

Entrevistadora Claudia: Não tem problema, pensa. Se você não conseguir não tem problema. Mas o que é viver com a dislexia, como...

Entrevistado Tiago: Eu diria que é uma vida normal, você só vai ter um pouco de dificuldade, mas você vai superar as dificuldades, vai conseguir superar tudo. Você tem um certo atraso no ensino, mas se você conseguir o apoio da família, conseguir um bom apoio não só família, mas de médico, etc., você consegue superar.

Entrevistadora Claudia: Como que... Não, não, desculpa, pode continuar.

Entrevistado Tiago: Tudo bem. Às vezes pode ser difícil para a família. No caso, não foi na dislexia em sim, mas quando minha família descobriu que eu tinha a DDA, o <ininteligível - 0:14:20.6> de atenção, foi um 
choque. Porque a minha irmã ela é, digamos que ela é normal. Ela estuda para caramba, etc. E [as coisas] dos meus pais eu tivesse atraso, então foi um choque. E ainda bem que se descobriu isso ainda quando eu era muito jovem, com o tempo, foi bem cedo, então deu para... Como eu diria? Deu para a gente correr atrás prejuízo.

Entrevistadora Claudia: Sim, sim. Claro. Então assim, para a gente ir terminando, tenta fazer para mim uma comparação então da época que você fazia inglês nessa escola, na Seven, agora que você tem atenção do professor particular, tenta falar um pouco para mim as diferenças. De sensação, como que você se sente, como que é o seu aprendizado? Tenta só dar uma comparada para mim. O antes e o agora.

Entrevistado Tiago: Eu acho que o antes era... acho que era só mais um aluno qualquer, que estava pagando uma escola normal, que não fazia diferença nenhuma para uma instituição como aquela, não é? E agora eu acho que eu me sinto um pouco, no meu ver, eu me sinto um pouco mais importante.

Entrevistadora Claudia: Entendi. Eu acho que das minhas perguntas é só isso. Então é isso mesmo, Tiago. Olha, super obrigada, viu?

Entrevistado Tiago: De nada, que é isso.

Entrevistadora Claudia: Você me ajudou tremendamente. Então a gente termina por aqui. 
